\title{
Recent Progress in Hybrid Biocomposites: Mechanical Properties, Water Absorption, and Flame Retardancy
}

\author{
Mohsen Bahrami * (), Juana Abenojar(i) and Miguel Ángel Martínez® \\ Materials Science and Engineering and Chemical Engineering Department, University Carlos III de Madrid, \\ 28911 Leganes, Spain; abenojar@ing.uc3m.es (J.A.); mamc@ing.uc3m.es (M.Á.M.) \\ * Correspondence: mbahrami@ing.uc3m.es; Tel.: +34-91-6249401
}

Received: 4 October 2020; Accepted: 12 November 2020; Published: 15 November 2020

check for updates

\begin{abstract}
Bio-based composites are reinforced polymeric materials in which one of the matrix and reinforcement components or both are from bio-based origins. The biocomposite industry has recently drawn great attention for diverse applications, from household articles to automobiles. This is owing to their low cost, biodegradability, being lightweight, availability, and environmental concerns over synthetic and nonrenewable materials derived from limited resources like fossil fuel. The focus has slowly shifted from traditional biocomposite systems, including thermoplastic polymers reinforced with natural fibers, to more advanced systems called hybrid biocomposites. Hybridization of bio-based fibers/matrices and synthetic ones offers a new strategy to overcome the shortcomings of purely natural fibers or matrices. By incorporating two or more reinforcement types into a single composite, it is possible to not only maintain the advantages of both types but also alleviate some disadvantages of one type of reinforcement by another one. This approach leads to improvement of the mechanical and physical properties of biocomposites for extensive applications. The present review article intends to provide a general overview of selecting the materials to manufacture hybrid biocomposite systems with improved strength properties, water, and burning resistance in recent years.
\end{abstract}

Keywords: biocomposites; green polymers; hybrid composites; natural fibers; mechanical properties

\section{Introduction}

Nowadays, global environmental safety, ecological concerns, recyclability, eco-efficiency, and economic factors are fundamental driving forces to increase the employment of bio-based materials [1,2]. The EU Bioeconomy Strategy [3] is one of the developed plans or policies to accelerate the UN Sustainable Development Goals (SDGs). This strategy focuses not only on shifting from fossil resources to renewable raw materials but also on recycling renewable bio-based raw materials and innovating in the production and consumption of materials [3]. In this regard, biocomposites are among the potential sectors for the bioeconomy. Renewable and sustainable biomaterials as an alternative for petroleum-based materials prevent generating carbon dioxide causing global warming. They would be a solution to alleviating the petroleum supplies' uncertainty, which are about to decline shortly $[4,5]$. Within recent years, biopolymers or green polymers have received tremendous interest among biomaterials. The term biopolymer is a polymer of monomeric molecules derived from natural resources, including biological systems or living organisms. Moreover, biopolymers can be found in nature and daily life, such as natural rubber, starch, cotton, leather, wool, etc. [6-8]. Biopolymers are renewable, environmentally friendly, or/and biodegradable materials, which can be divided into two broad groups of natural and synthetic (Figure 1) with the following origins [9-13]:

- Natural biopolymers extracted from biomass (e.g., polysaccharides, proteins) 
- Synthetic biopolymers produced by a micro-organism or bacteria (e.g., bacterial cellulose, polyhydroxyvalerate, polyhydroxybutyrate)

- Synthetic biopolymers synthesized from renewable bio-based monomers or mixed sources of biomass and petroleum (e.g., polylactic acid, aliphatic polyester, aliphatic-aromatic copolyesters)

- Biodegradable polymers that are derived from nonrenewable resources (petroleum sources) (e.g., polycaprolactone)

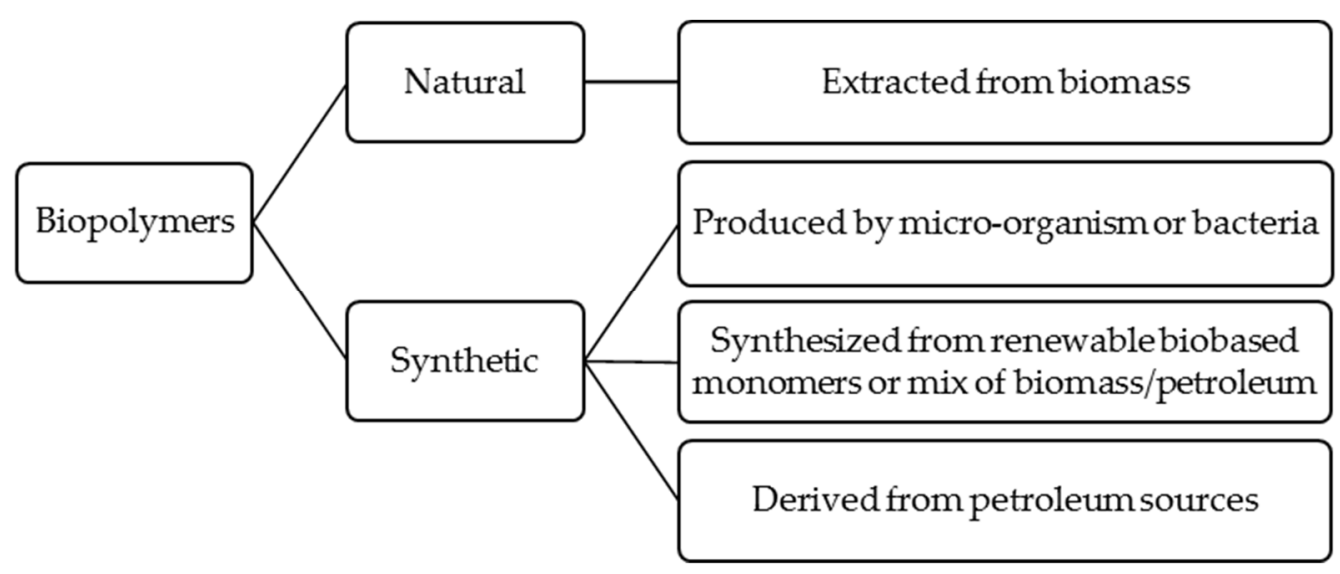

Figure 1. Origins of biopolymer materials [CMB, JA, MAM_UC3M2020].

Despite the advantages of biopolymer materials, they have some limitations compared to petroleum-based materials, such as relatively low stiffness, tensile strength, permeability, and thermal stability $[8,9]$. Therefore, to modify biopolymers' properties and commercial importance, "biopolymer composites" are tremendously explored by adding reinforcement materials within the micro or nanoscale [14-18]. These composites have a large assortment of applications in construction, medicine, electronics, packaging, and automotive sectors [19-24].

Composite materials systems are made from one or more discontinuous reinforcing phases embedded in a continuous matrix phase. Biopolymer composites or biocomposites are referred to as composites in which at least one constituent is bio-based or biodegradable [25]. The focus of this review will be on the fibrous composites rather than laminate and particulate composites. Fibrous composites can be made of natural/biofiber and synthetic fiber. Biocomposite systems can be classified into partial biodegradable and complete biodegradable biocomposites on the basis of the matrix and fibers (Figure 2) [2,5,26]. In the complete biodegradable biocomposites, bio-fibers are employed with the matrices are made of biodegradable polymers such as renewable biopolymer matrices (e.g., cellulosic plastic, soy plastic, starch plastic) or petro-based biodegradable polymer matrices (e.g., aliphatic co-polyester, polyesteramides). However, in the partial biodegradable biocomposites, bio-based matrices are reinforced with synthetic fibers, or non-biodegradable polymers matrices such as traditional thermoplastic polymers (e.g., polypropylene, polyethylene) and thermoset polymers (e.g., epoxy, polyester) are reinforced with bio-fibers [5,26]. It is worth noting this classification of biocomposites does not estimate time or amount of degradation, which depends on many parameters, such as environment, temperature, and micro-organisms and can be defined by standard degradation tests. This classification emphasizes that if both fibers and matrix be $100 \%$ biodegradable materials, a composite will decompose at the end of its life and completely go back into the natural environment. Otherwise, if one of them be non-biodegradable, the composite doesn't show full biodegradability properties. Recently, the blending of two or more polymers reinforced with one or more fibers that produce hybrid composites materials has become an effective way to manipulate biocomposites properties and maintain the balance among ecology-economy-technology. The present study reviews the recent progress of hybrid biocomposites in improving their mechanical properties, water, and burning resistance. 


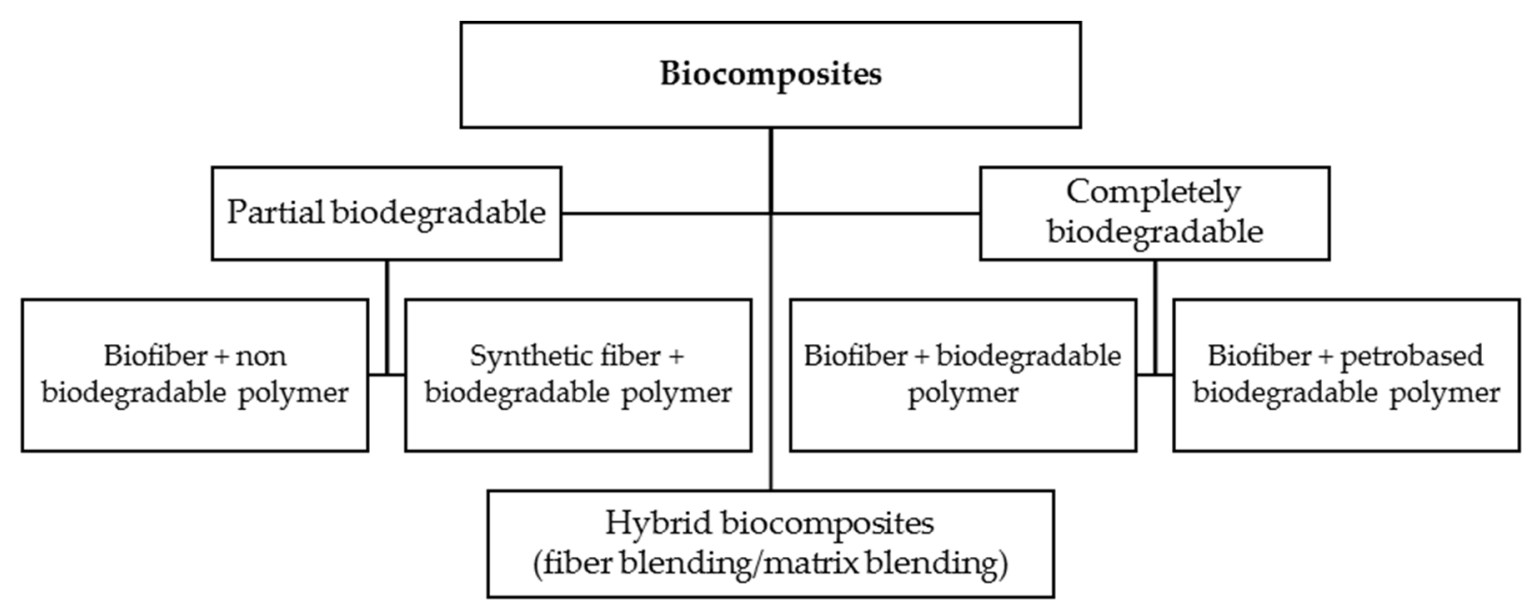

Figure 2. Classification of biocomposites. Adapted from [5].

\section{Hybridization}

The concept of hybridization can be found in various fields, such as mechanics, polymer and chemistry, metallurgy, physics, science and technology, and energy fuels. Regardless of the research area, this process's main objective is to combine three or more materials to achieve improved performance or properties compared to each substance for a proposed application [27]. In the field of composite materials, by incorporating two or more filler/fiber into a matrix material, the disadvantages of one type of reinforcement can be reduced by another one [28]. For example, by hybridization of natural fibers with any synthetic fibers, although the main benefits of natural fiber composites such as biodegradability, easy handling and processing, and natural resources are being reduced, hybridization can decrease the cost, weight, and environmental concerns produced by the synthetic fiber composites effectively. Several publications scientifically prove that hybridization techniques can enhance the composites' mechanical, thermal, and dynamic characteristics, such as minimizing water absorption and increasing flame retardancy [29-31]. The main parameters, which significantly affect the properties of the manufactured hybrid composite products, are as follows [27]:

- Materials selection (matrix and fiber), which depend mostly on the proposed application;

- Preparation technique, which depends on the fiber, matrix, and working conditions (viz. outdoors or indoors);

- Interaction between the fibers and matrix, which can be controlled by fiber treatment or the use of coupling agents.

Considering the mentioned parameters is significantly essential, since they could cause unexpected effects in the results. Many studies have reported adverse effects of hybridization due to the inappropriate selection of materials, processing techniques, a sequence of layers in a hybrid structure, and the loading arrangement. For instance, Sreekala et al. [32] reported a negative effect of oil palm empty fruit bunch (OPEFB) fiber hybridization on the tensile strength and tensile modulus at very low and high fiber volume fractions. Zweben [33] predicted that high elongation fibers might behave like crack arrestors on a micromechanical level when introduced in low elongation fiber composites. This behavior increases the strain level needed for fiber break propagation. Hariharan and Abdul Khalil [34], who hybridized oil palm fibers with glass fibers, also stated an undesired hybrid effect on the strength properties. Marom et al. [35] investigated positive or negative hybrid effects in hybrid composites as a positive or negative deviation of a specific mechanical property according to the rule-of-mixtures behavior. It is based on the weighted average of the characteristic properties of the distinct composites [36]. Based on biocomposites classification (Figure 2) and the concept of hybridization, different configurations of hybrid fiber-reinforced biocomposites could be manufactured as some of them are depicted in Figure 3. 
(a)
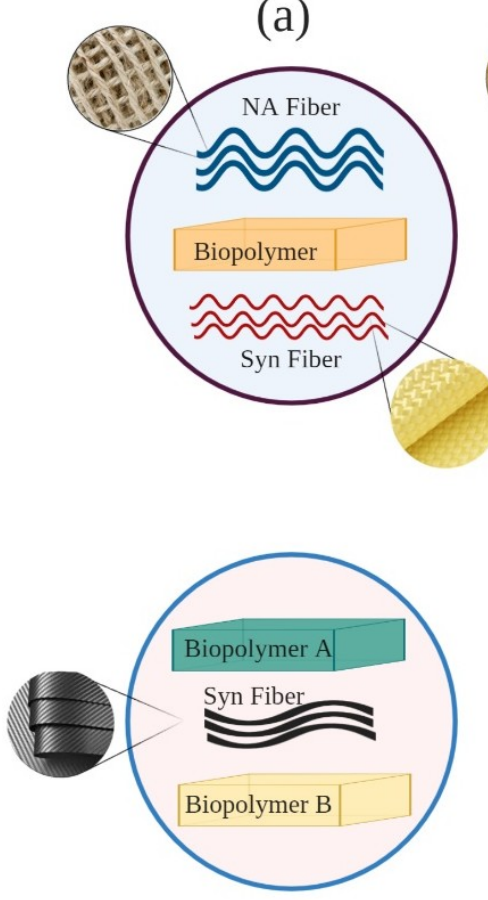

(d) (b)
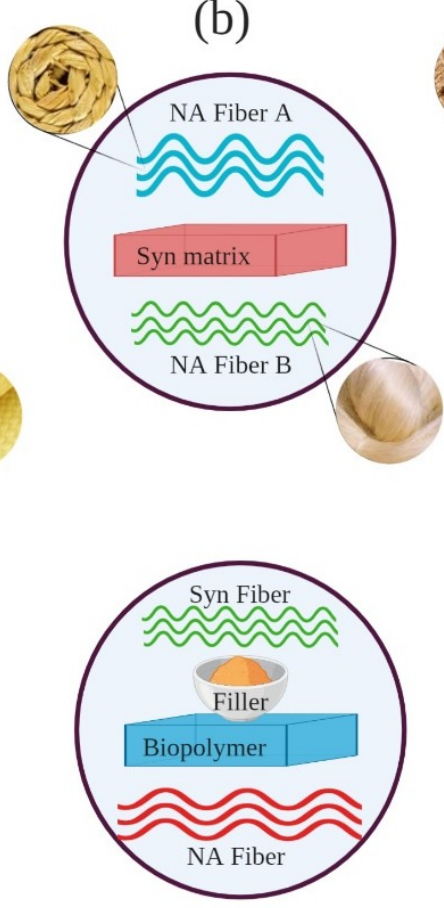

(e) (c)
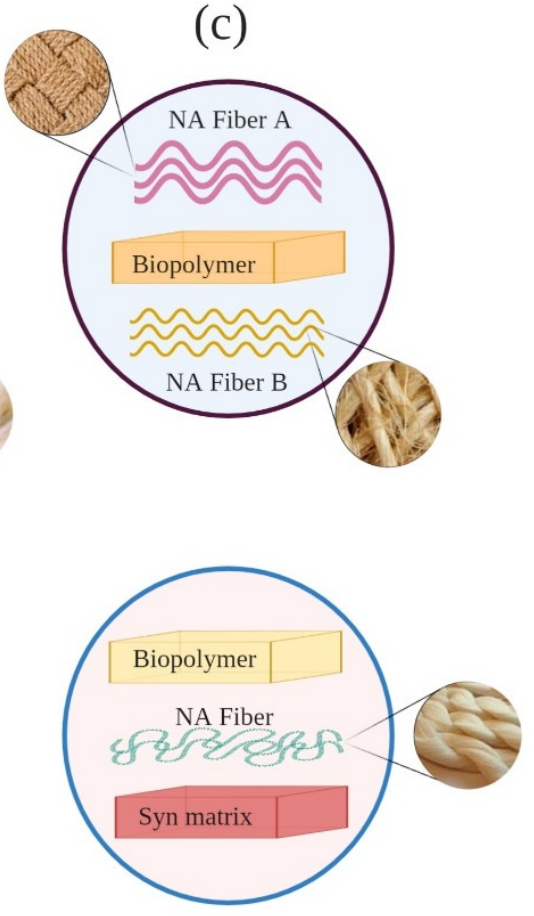

(f)

Figure 3. Some configurations of hybrid biocomposites (NA: natural, Syn: synthetic): (a) hybridization of natural and synthetic fibers with biopolymer matrix; (b) hybridization of two or more natural fibers with synthetic matrix; (c) hybridization of two or more natural fibers with biopolymer matrix; (d) hybridization of two or more biopolymer matrices with synthetic fiber; (e) hybridization of natural and synthetic fibers with fillers with biopolymer matrix (f) hybridization of biopolymer and synthetic matrices with natural fiber. [CMB, JA, MAM_UC3M2020].

\section{Materials Selection}

\subsection{Fiber Selection}

Fibers' function as a discontinuous reinforcement phase in fiber-reinforced composites is modifying properties to obtain desired enhancement in the composite structure's strength or/and stiffness. They can be subdivided into synthetic or natural fibers according to their origin, as illustrated in Figure $4[37,38]$. 

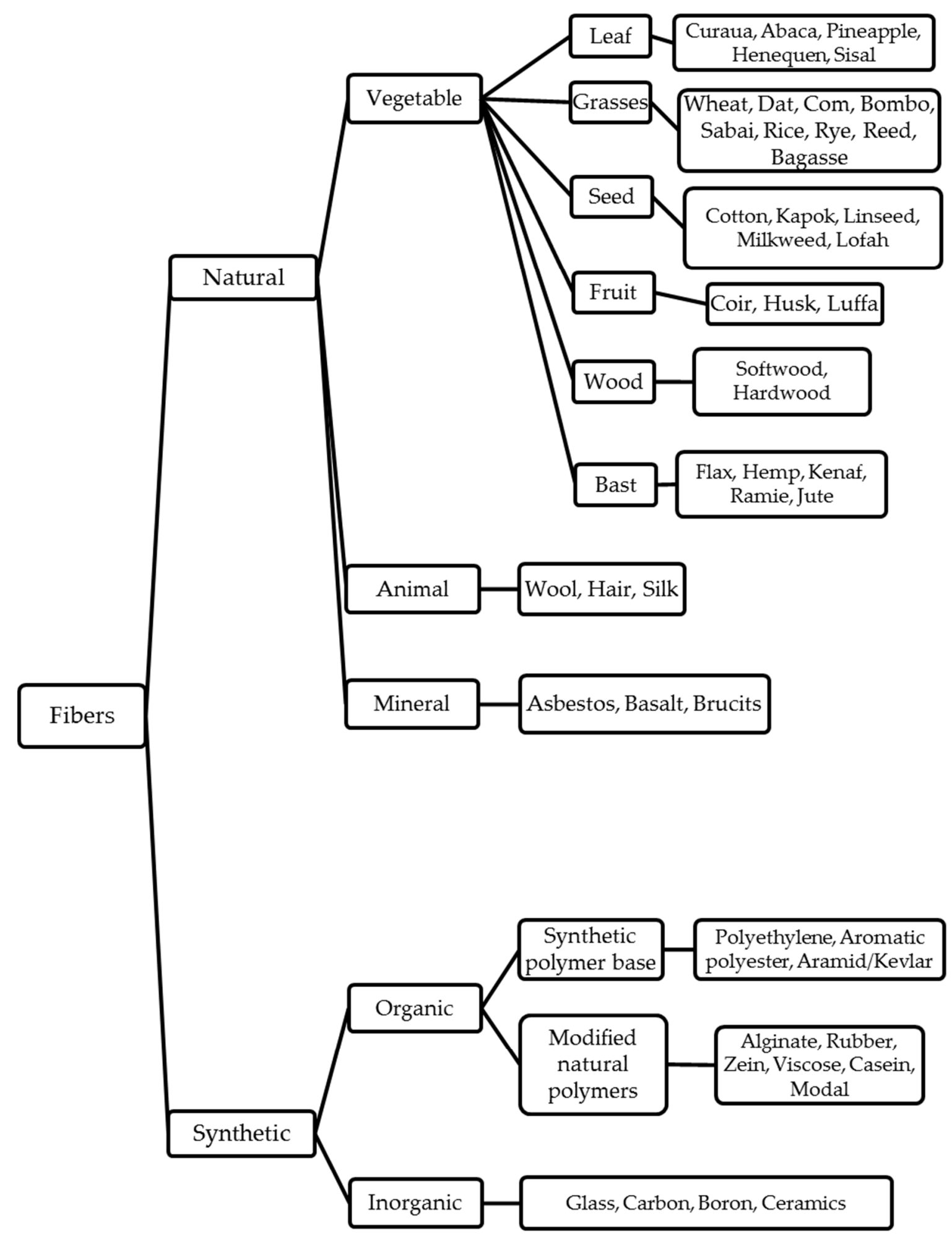

Figure 4. Classification of natural and synthetic fibers. Adapted from [38].

\subsubsection{Natural Fibers}

Natural fibers can be extracted from different renewable resources of animals, vegetable plants, and minerals. The major constituents of natural fibers are cellulose, hemicellulose, lignin, and pectin, and their general chemical structures are illustrated in Figure 5 [39]. 
(a) Cellulose

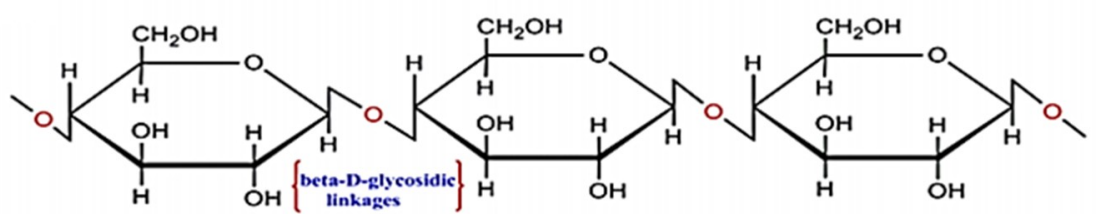

(b) Hemicellulose
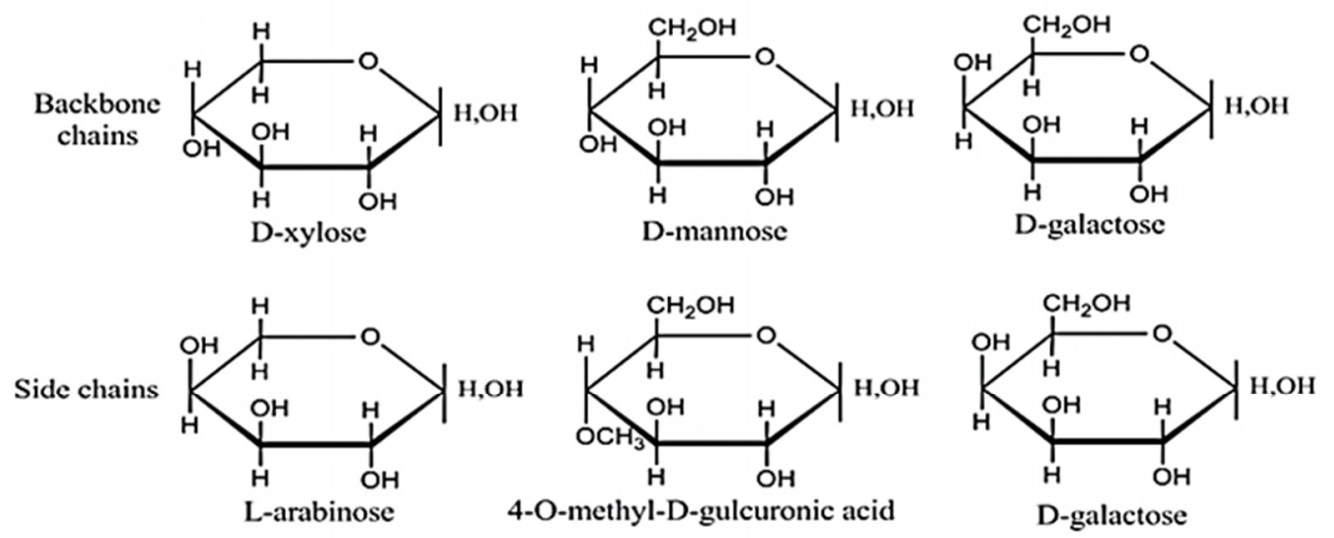

(c) Phenols in Lignin<smiles>COc1cc(C=CCO)ccc1O</smiles><smiles>COc1cc(C=CCO)cc(OC)c1O</smiles><smiles>OCC=Cc1ccc(O)cc1</smiles>

Trans-p-coumaryl

(d) Pectin

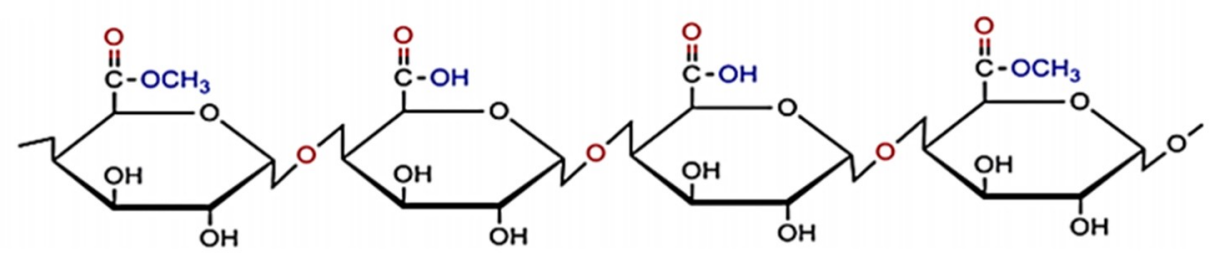

Figure 5. Chemical structure of the major constituents in the natural fibers: (a) cellulose;

(b) hemicellulose; (c) lignin; (d) pectin. Adapted from [38].

Cellulose, which is the most abundant organic polymer on earth, includes plenty of $\beta$-D-glucose $\left(\mathrm{C}_{6} \mathrm{H}_{11} \mathrm{O}_{5}\right)$ units linked by glycoside linkages at the $\mathrm{C}_{1}$ and $\mathrm{C}_{4}$ carbon positions (Figure 5a) [40,41]. Cellulose, which is strong and durable, exists in both microcrystalline and amorphous structures with regions of a high order and low order, respectively [1]. It is resistant to strong alkali and oxidizing agents. Still, it is susceptible to hydrolysis with acid to water-soluble sugars and also is degradable when exposed to chemical and solution treatments [13].

Hemicellulose is the second-largest biomolecules, which includes polysaccharide units comprised of a highly branched polymer of carbon ring sugars (Figure $5 b$ ). It has a lower degree of polymerization and much shorter chains in comparison to cellulose. Moreover, it is hydrophilic and soluble in alkali solutions [26,42]. It can bond to the cellulose and lignin components in the cell wall to increase fibers' rigidity and flexibility [43].

Lignin is a complex nanocrystalline molecule with hydroxyl, methoxyl, and carbonyl functional groups; however, lignin's exact chemical nature remains unknown (Figure 5c). Lignin is formed within a plant cell wall composed of aromatic units and is amorphous and insoluble in most solvents. 
This biochemical polymer is a high molecular-weight phenolic compound, generally resistant to microbial degradation, and cannot be broken down to a monomeric unit $[1,2,44,45]$. When the hydrophobic lignin acts as a compatibilizer between hydrophilic cellulose and hemicellulose, it can improve the plant's stiffness [46,47].

Pectin includes a complex group of heteropolysaccharides called galacturonoglycans with different methyl ester content. The simplest pectin, as presented in Figure 5d, is homogalacturonan (HG) and an unbranched polymer of $\alpha-(1-4)$ linked D-galacturonic acid [48]. Pectin indicates the luster and touch of fibers and acts as a binder of fibers into the bundles [45].

Wax makes mainly the outer part of the natural fibers and consists of different types of alcohol, which are soluble in water and acids. Wax provides a soft touch, low friction that results in fibers moving [45,49]. This constitution also affects the wettability and adhesion between fiber and matrix [50].

Natural fibers' chemical composition, which depends on plant species, age, climate, and soil conditions, is crucial in their performance and application. Each constitution can induce different types of susceptibility to the natural fibers, i.e., biological, chemical, mechanical, thermal, photochemical, and aqueous. For example, cellulose is a governing constitute to improve the strength and modulus of fibers. Hemicellulose is in charge of biological and thermal degradation besides high water absorption (2.6 times higher than lignin); however, lignin mainly controls UV and fire degradation [43,51-53]. Another critical parameter of natural fibers that highly affect their mechanical properties is microfibrils' orientation to the cell axis, determining the fibers' stiffness [54]. Table 1 shows the chemical composition and structural parameters of common natural fibers.

Table 1. Chemical composition of various natural fibers.

\begin{tabular}{|c|c|c|c|c|c|c|c|}
\hline Fiber & $\begin{array}{c}\text { Cellulose } \\
(\%)\end{array}$ & $\begin{array}{c}\text { Hemicellulose } \\
(\%)\end{array}$ & $\begin{array}{l}\text { Lignin } \\
(\%)\end{array}$ & $\begin{array}{c}\text { Pectin } \\
(\%)\end{array}$ & $\begin{array}{l}\text { Wax } \\
(\%)\end{array}$ & $\begin{array}{c}\text { Microfibrillar } \\
\text { Angle } \\
\left({ }^{\circ}\right)\end{array}$ & Ref. \\
\hline \multicolumn{8}{|l|}{$\begin{array}{l}\text { Bast/Stem } \\
\text { fiber }\end{array}$} \\
\hline Flax & $64-81$ & $14-20.6$ & $2-5$ & $0.9-2.3$ & 1.7 & $5-10$ & {$[53,55-59]$} \\
\hline Hemp & 57-92 & $14-22.4$ & $3.7-13$ & 0.9 & 0.8 & $2-6.2$ & {$[53-55,58-61]$} \\
\hline Jute & $45-84$ & $12-21$ & $5-13$ & 0.2 & 0.5 & 8 & [57-60] \\
\hline Kenaf & $44-72$ & $21-24$ & $8-21$ & $2-5$ & - & $2-6.2$ & {$[38,53,55,61]$} \\
\hline Ramie & $68.6-76.2$ & $5-16.7$ & $0.6-1$ & $1.9-2$ & 0.3 & 7.5 & {$[53,56-60]$} \\
\hline Banana & $60-65$ & $6-19$ & $5-10$ & $3-5$ & - & 11 & {$[53,58,62]$} \\
\hline Nettle & 86 & 10 & 5.4 & 0.6 & $3.1-4$ & - & {$[38,60,61,63]$} \\
\hline \multicolumn{8}{|l|}{ Leaf fiber } \\
\hline Sisal & $43-78$ & $10-24$ & $4-13$ & $0.8-2$ & 2 & $10-22$ & $\begin{array}{c}{[53,55,57,58,60,} \\
62,64]\end{array}$ \\
\hline Curaua & $70.7-73.6$ & $4-9.9$ & $7.5-13.1$ & - & - & - & {$[38,56,60,61]$} \\
\hline Pineapple & 80-83 & $15-20$ & $4.6-12$ & $2-4$ & $4-7$ & $8-15$ & {$[38,58,63,65]$} \\
\hline Abaca & 56-64 & $21-25$ & $7-13$ & $0.8-1$ & 3 & - & {$[56,58,60,62]$} \\
\hline Henequen & $60-77.6$ & $4-8$ & $8-13.1$ & - & 0.5 & - & {$[38,57,59,60]$} \\
\hline \multicolumn{8}{|l|}{$\begin{array}{l}\text { Fruit/Seed } \\
\text { fiber }\end{array}$} \\
\hline Cotton & $82-96$ & $2-6$ & $0.5-1.6$ & $0-7$ & 0.6 & $20-30$ & {$[38,55,58,60]$} \\
\hline Coir & $36-46$ & $0.15-0.3$ & $41-45$ & $3-4$ & - & $30-49$ & {$[53,55,56,58,66]$} \\
\hline Oil palm & 65 & 0-29 & 19 & - & 4 & 46 & {$[38,56,60,62]$} \\
\hline \multicolumn{8}{|l|}{ Wood } \\
\hline Hardwood & $43-47$ & $25-35$ & $16-24$ & - & - & - & {$[38]$} \\
\hline Softwood & $40-44$ & $25-29$ & $25-31$ & - & - & - & {$[38,53]$} \\
\hline \multicolumn{8}{|l|}{ Grass fiber } \\
\hline Bagasse & $32-55.2$ & $16.8-21$ & $19.9-25.3$ & 10 & - & - & {$[56,60,63]$} \\
\hline Bamboo & $26-43$ & $15-30$ & 21-31 & - & - & - & {$[53,56,58,60]$} \\
\hline Rice & $28-57$ & 33 & 8-19 & $8-38$ & - & - & [56] \\
\hline Wheat & $29-45$ & $15-31$ & $13-20$ & - & - & - & {$[53,56,60]$} \\
\hline
\end{tabular}


The relatively good specific mechanical and physical properties of natural fibers are due to their low density and particular microstructure. Table 2 compares the physical and mechanical properties of some natural and synthetic fibers. Furthermore, the natural fibers' pros and cons with respect to the synthetic fibers are listed in Table 3. Since the pros and cons depending on the application of fibers, it is worth mentioning that Table 3 was written to utilize fibers in biocomposite with environmental, economic, recycling, and eco-efficiency concerns. In this regard, for example, breaking down the fibers with micro-organisms to $\mathrm{CO}_{2}$, methane, and biomass (biodegradability) would be an advantage for environmental concerns.

Table 2. Mechanical properties of some natural and synthetic fibers.

\begin{tabular}{|c|c|c|c|c|c|}
\hline Fiber & $\begin{array}{l}\text { Density } \\
\left(\mathrm{g} / \mathrm{cm}^{3}\right)\end{array}$ & $\begin{array}{c}\text { Tensile Strength } \\
\text { (MPa) }\end{array}$ & $\begin{array}{l}\text { E-Modulus } \\
\text { (GPa) }\end{array}$ & $\begin{array}{c}\text { Elongation at } \\
\text { Break }(\%)\end{array}$ & Ref. \\
\hline \multicolumn{6}{|l|}{ Bast fiber } \\
\hline Flax & 1.5 & $345-1100$ & 27.6 & $0.2-3.2$ & {$[50,56,57,60]$} \\
\hline Hemp & 1.48 & 690 & $30-70$ & $1.6-4$ & {$[54,56,57,60]$} \\
\hline Jute & $1.3-1.45$ & $393-773$ & $10.0-30.0$ & $1.2-1.8$ & {$[50,56,57,60]$} \\
\hline Kenaf & - & 930 & $22.0-60.0$ & 1.6 & {$[50,56,60]$} \\
\hline Ramie & 1.5 & $400-938$ & $44-128.0$ & $1.2-3.8$ & {$[50,57,59,61]$} \\
\hline \multicolumn{6}{|l|}{ Leaf fiber } \\
\hline Sisal & 1.5 & $468-640$ & $9.4-22.0$ & $3.0-7.0$ & {$[56,57,59,67]$} \\
\hline Curaua & 1.4 & 500-1150 & 9-11.8 & $3.7-7.5$ & {$[50,56,60]$} \\
\hline Pineapple & 1.5 & $413-1627$ & $34.5-82.5$ & $0.8-1.6$ & {$[38,50,62,63]$} \\
\hline Abaca & 1.5 & 400 & 12.0 & $3.0-10.0$ & {$[50,56,60,61]$} \\
\hline \multicolumn{6}{|c|}{ Fruit/Seed fiber } \\
\hline Cotton & $1.5-1.6$ & $287-800$ & $5.5-12.6$ & $7.0-8.0$ & {$[50,59,60]$} \\
\hline Coir & 1.2 & $131-175$ & $4.0-6.0$ & $15.0-40$ & {$[50,56,59,60]$} \\
\hline Oil palm & $0.7-1.55$ & 248 & 3.2 & 25.0 & {$[50,56,60,61]$} \\
\hline \multicolumn{6}{|l|}{ Grass fiber } \\
\hline Bagasse & 1.25 & 290 & $11-17$ & - & {$[50,56,60,62]$} \\
\hline Bamboo & $0.6-1.1$ & $140-441$ & $11-17$ & - & {$[50,55,56,60]$} \\
\hline \multicolumn{6}{|c|}{ Synthetic fiber } \\
\hline Aramid & 1.4 & $3000-3150$ & $63.0-67.0$ & $3.3-3.7$ & {$[50,57,59]$} \\
\hline Carbon & 1.7 & 4000 & $230-240$ & $1.4-1.8$ & {$[50,57,59]$} \\
\hline E-glass & 2.5 & $2000-3500$ & 70.0 & 2.5 & {$[55,57,59,62]$} \\
\hline S-glass & 2.5 & 4570 & 86.0 & 2.8 & {$[50,57,59,62]$} \\
\hline
\end{tabular}

Table 3. Natural fibers' advantages and disadvantages. Adapted from [68-70].

\begin{tabular}{|c|c|}
\hline Advantages & Disadvantages \\
\hline Biodegradability & High water absorption \\
\hline Renewability & Limited processing temperature \\
\hline Low density & Dimensional instability \\
\hline $\begin{array}{l}\text { High filling levels and non-abrasive to the molding } \\
\text { machinery }\end{array}$ & Poor fire resistance \\
\hline Easily colored & Lower strength and lower thermal resistance \\
\hline Non-abrasive to processing equipment & Anisotropic behavior \\
\hline Good thermal and acoustic insulating properties & Sensitive to UV, microbial and fungus attach \\
\hline $\begin{array}{c}\text { Friendly processing atmosphere, non-harmful gases } \\
\text { generation, reduced thermal and respiratory } \\
\text { irritations }\end{array}$ & $\begin{array}{l}\text { The volatility of properties and price based on the } \\
\text { location }\end{array}$ \\
\hline Zero fingerprint $\mathrm{CO}_{2}$ & Incompatibility with most hydrophobic polymers \\
\hline Low production energy & Poor fiber/matrix adhesion \\
\hline Non-brittle fracture on impact & Lower strength, especially impact strength \\
\hline
\end{tabular}




\subsubsection{Engineered Fibers}

Engineered or synthetic fibers can be either organic or inorganic. The organic fibers are commonly divided into modified natural and synthetic polymers (Figure 4). The inorganic fibers are mostly derived from petroleum-based by-products and a combination of different chemicals. Glass, carbon, and aramid fibers are the most frequently used synthetic fibers in composites in varied areas of aerospace, defense, construction, sports, naval, etc. One of these fibers' benefits over natural ones is that they are independent of growing conditions and can be manufactured with distinct functionalities needed for the proposed application [29,71]. Synthetic fibers are well known for their superior mechanical and thermal properties as compared to natural fibers. For example, carbon fibers with a wide range of aspect ratio, low thermal expansion, high stiffness, tensile strength, chemical resistance, and temperature tolerance are utilized as multifunctional fillers to improve polymers properties [72]. Glass fibers with low cost, high tensile strength, high chemical resistance, and excellent insulating properties are employed to manufacture the largest group of composite materials that is glass fiber-reinforced polymer (GFRP) composites. Glass fibers with varied forms such as long longitudinal, woven mat, chopped strand fiber, and chopped strand mat are incorporated into matrix to enhance mechanical and tribological properties of polymer composites [73]. Aramid fibers are mainly employed in high temperatures and high resistance applications such as manufacturing body parts in the aerospace and automobile industry, ballistic accessories in the military, boat hulls, heat-resistant helmets, etc. Their specific properties include high abrasive resistance, good fabric integrity at elevated temperatures, no melting point, high degradation temperature (starting from $500^{\circ} \mathrm{C}$ ), and low flammability $[29,73]$.

\subsection{Matrix Selection}

A matrix in the composites provides the overall durability, including surface appearance, shape, and environmental tolerance. Another function of the matrix is to efficiently bind the fibers to transfer load between them [74]. These matrices depending on the processing technique and type of bonding present in them can be classified into thermoplastic and thermosets. Major polymers used as a matrix for composites are presented in Table 4.

Table 4. Major polymers used as a matrix for composites.

\begin{tabular}{cc}
\hline \multicolumn{1}{c}{ Polymers } & \\
Thermoplastics & Thermosets \\
\hline Polylactic acid (PLA) & Epoxy \\
Poly butylene succinate (PBS) & Phenolic \\
Polyhydroxyalkanoate (PHA) & Polyester \\
Polyamide (PA) & Polyurethane (PU) \\
Polyethylene (PE) & Vinyl ester \\
Polycarbonate (PC) & Silicone \\
Polyvinyl chloride (PVC) & Melamine \\
Polystyrene (PS) & - \\
Polypropylene (PP) & - \\
Polyurethane (PU) & - \\
\hline
\end{tabular}

Both thermoplastics and thermosets polymers have certain advantages and disadvantages as matrix materials in polymer matrix composites (PMC). The primary difference between thermoset and thermoplastic polymers is their behavior in exposure to heat. Thermoplastics can be reheated, remolded, and reprocessed into a new shape without any chemical changes, while thermosets that strengthen after heating cannot be remolded or dissolved in a solvent $[74,75]$. This behavior is attributed to the polymer chains' interaction with each other. This interaction in thermosets is strong covalent bonds and chains have a highly cross-linked structure [76]. Therefore, thermoset resins such as epoxy, polyester, and polyamide have excellent dimensional stability and resistance against high temperatures without losing their structural integrity. Moreover, they have limited water absorption, high modulus, 
high strength, and good chemical resistance. The major drawback of thermosets is that recycling and reprocessing are virtually impossible after the initial forming $[77,78]$. On the other hand, thermoplastics that also have non-covalent bonds (i.e., relatively weak Van der Waals forces between long-chain molecules) are often chosen over thermosets due to their reversible changes, recyclability, moldability into various shapes, relatively low processing costs, and easy manufacturing with high volume and precision [79].

Resins or matrices in the concept of biopolymer can be defined by two criteria (Figure 6): (1) biodegradability of the polymer, (2) source of raw materials [80]. The first group (A) of resins are biodegradable biopolymers made from renewable raw materials (bio-based). The second group (B) of resins are non-biodegradable biopolymers made from renewable raw materials (bio-based). The last group $(\mathrm{C})$ of resins are biodegradable biopolymers made from fossil fuels. The biodegradable bio-based resins (type A) are divided into three groups: (1) synthetic polymers from renewable resources, e.g., PLA; (2) biopolymers generated by micro-organisms, e.g., PHA; (3) natural occurring biopolymers, e.g., starch or proteins. The non-biodegradable bio-based resins (type B) that can be produced from biomass or renewable resources are divided into two groups: (1) synthetic polymers from renewable resources such as specific PAs from castor oil (PA 11); (2) natural occurring biopolymers, e.g., natural rubber or amber. The biodegradable resins of type $C$, such as polybutylene succinate (PBS) and polycaprolactone (PCL), are produced from fossil fuel such as synthetic aliphatic polyesters made from crude oil or natural gas $[59,80,81]$. Accordingly, not all the bio-based polymers are biodegradable, and not all the biodegradable polymers are bio-based, while some belong to both, such as PHA. Based on the above categories, the biopolyethylene derived from sugarcane, namely "green polyethylene," developed recently, is classified in type B of novel biopolymers [82].

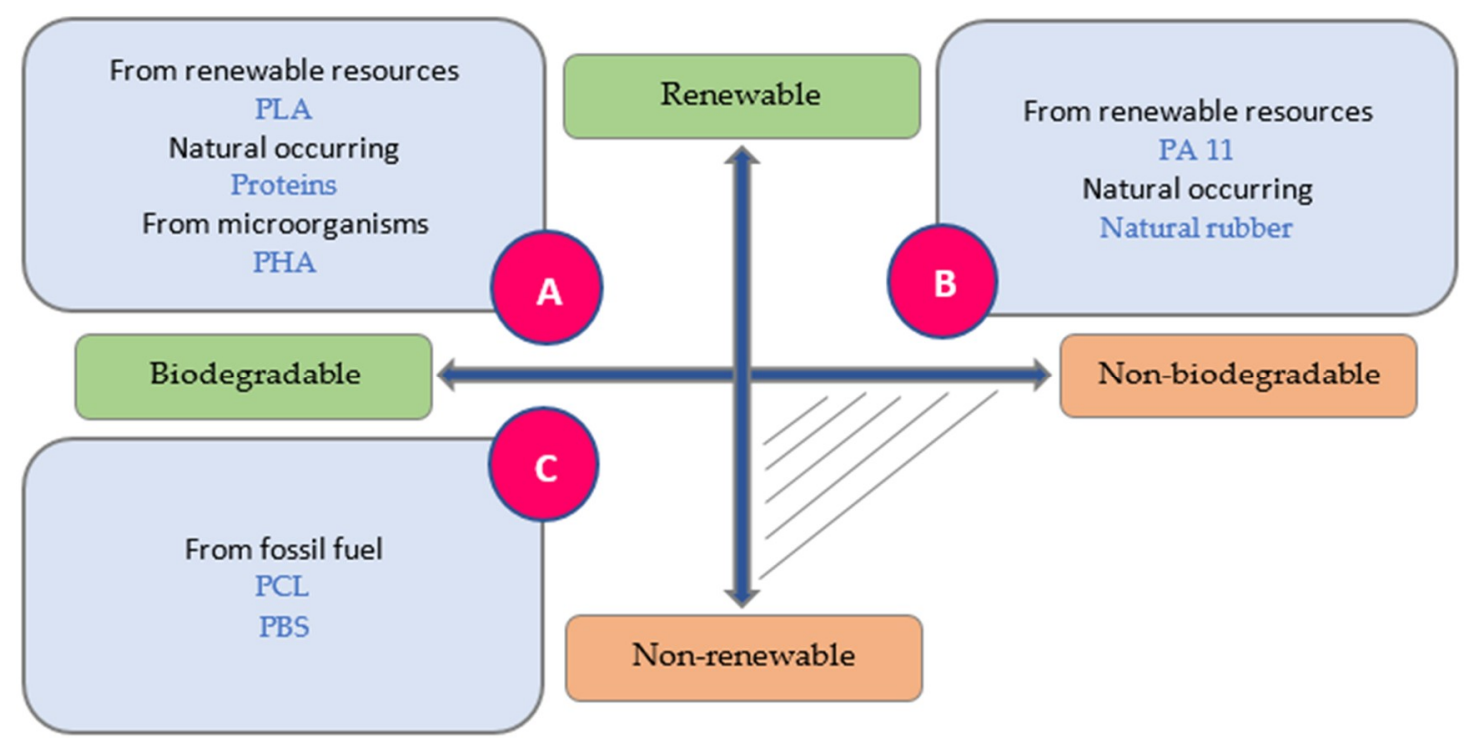

Figure 6. Biopolymer matrices classifications [CMB, JA, MAM_UC3M2020].

\subsubsection{Bio-Based Thermoplastics}

The bio-based thermoplastics with renewable resources have attracted significant attention as an alternative to oil-based thermoplastics in recent years. In this section, some of the most critical bio-based thermoplastics are explained.

- Polylactic acid

Polylactic acid (PLA) is the most extensively explored and utilized biodegradable thermoplastic material produced from plant-derived carbohydrates such as glucose and starch, which are achieved from corn, potatoes, beets and cane, and so forth $[83,84]$. PLA with backbone formula $\left(\mathrm{C}_{3} \mathrm{H}_{4} \mathrm{O}_{2}\right)_{\mathrm{n}}$ 
(Figure 7a) is a hydrophobic polyester with a basic monomer of lactic acid. This monomer can be polymerized to PLA by direct polycondensation, ring-opening polymerization, solid-state polymerization, and azeotropic condensation polymerization $[85,86]$. PLA polymer can be amorphous, semi-crystalline, and highly crystalline polymer depending on the stereoisomer composition. PLA's mechanical properties depend on various parameters, e.g., component isomers, processing temperature, annealing time, and molecular weight $(\mathrm{Mw})$. Generally, it has high strength and moderate barrier properties. Simultaneously, it is relatively less thermally stable, decomposing below $230{ }^{\circ} \mathrm{C}$ and has a poor toughness with a low deformation at the break. For example, semicrystalline PLA, which is preferred over the amorphous PLA from the mechanical properties point of view, has an approximate tensile modulus of $3 \mathrm{GPa}$, a tensile strength of $50-70 \mathrm{MPa}$, and an elongation at break of about $4 \%$ [86-88].

\section{- Polyhydroxyalkanoates}

Polyhydroxyalkanoate (PHA) is a family of water-insoluble, biodegradable, and biocompatible natural polyesters that are biosynthesized from micro-organisms, modified plants, or through chemical reactions $[89,90]$. This thermoplastic polymer covers a broad range of mechanical properties, from hard and brittle poly(3-hydroxybutyrate) (PHB) to soft and elastomeric poly(3-hydroxyoctanoate) (PHO) [91]. PHB homopolymer (Figure $7 \mathrm{~b}$ ) is the main variant of the PHA family that is highly crystalline (50-70\%), relatively hydrophobic, and an excellent gas barrier. Moreover, it has an elasticity modulus of $3 \mathrm{GPa}$, a tensile strength at break of $25 \mathrm{MPa}$, and has similar physical properties to conventional plastics such as polypropylene [92-94]. Due to the high melting temperature of PHB (about $173-180^{\circ} \mathrm{C}$ ), which is very close to its thermal decomposition temperature, it is hard to process it. Another drawback of PHB is an extreme brittleness due to the large spherulite formation and secondary crystallization [95]. The first attempt to overcome the mentioned disadvantages was the copolymerization of 3-hydroxybutyrate with other monomers to reduce the melting point and confer less stiffness [96]. Thus, various copolymers have been biosynthesized, such as poly(hydroxybutyrate-co hydroxyvalerate) (PHBV), poly(hydroxybutyrate-co-3-hydroxyhexanoate) (PHBHx), poly(hydroxybutyrate-co-hydroxyoctanoate) (PHBO), and poly(hydroxybutyrate cohydroxyoctadecanoate) (PHBOd) $[95,97]$. Furthermore, the reinforcing of PHAs with natural fibers could be another solution for brittleness and low-impact resistance [45].

\section{- Polybutylene succinate}

Polybutylene succinate (PBS) is one of the most favorable biodegradable polyesters, which is chemically synthesized through polycondensation of 1,4-butanediol and succinic acid or its anhydride in the presence of a catalyst $[98,99]$. This thermoplastic is a promising biopolymer owing to its mechanical properties and other beneficial properties, such as biodegradability, high crystallinity, melt processability, and thermal and chemical resistance. PBS consists of polymerized butylene units succinate with backbone formula $\left(\mathrm{C}_{8} \mathrm{H}_{12} \mathrm{O}_{4}\right)_{\mathrm{n}}$ (Figure $7 \mathrm{c}$ ). It is fully decomposed into biomass, $\mathrm{CO}_{2}$, and $\mathrm{H}_{2} \mathrm{O}$ like PLA [100,101]. Although PBS has many exciting properties, its softness, high electrical resistivity, and low gas barrier limit this polymer's practical applications. A diverse array of matrix polymers has been used to modify the PBS properties, such as PLA, poly( $\varepsilon$-caprolactone) and poly(hydroxybutyrate). Furthermore, adding reinforced fillers such as carbon nano tube (CNT), carbon black, layered silicate, and organoclay would be another method to improve PBS properties [102-105].

- Polyamide

Polyamide (PA) is a significant thermoplastic consisting of amide linkage $(-\mathrm{NH}-\mathrm{C}=\mathrm{O})$ (Figure $7 \mathrm{~d})$. Polyamides that are crystalline polymers and commonly known as nylon can be classified into many categories depending on monomers' arrangement and chemical nature. Aromatic, cycloaliphatic, and aliphatic polyamides are the most important ones [106,107]. Biopolyamides include both bio-based 
and biodegradable fossil fuel-based polyamides [80]. One of the most imperative bio-based polyamides is PA11, which is produced from 11-aminodecanoic acid derived from castor oil [108]. PA11 is a commercial aliphatic polyamide used in various fields, including automotive, food packaging, and offshore applications, thanks to its relatively good oil and saltwater resistance, biocompatibility, and lower hydrophilicity than PA 6 and $66[109,110]$. PA11 is a semi-crystalline polymer that is rigid at room temperature with a glass transition temperature $(\mathrm{Tg})$ of $43{ }^{\circ} \mathrm{C}$ [111]. Various efforts have been reported to improve the properties of PA11 that most of them have focused on the blending of PA11 with other polymers, especially bio-based ones like PLA [109,112,113], PHA [114,115] and PBS $[108,116]$ and also the incorporation of PA11 with inorganic fillers [117-119].<smiles>CCOC(=O)C(C)C</smiles>

(a)<smiles></smiles>

(c)<smiles>[R]C(CCC(C)C)OC(C)(C)C</smiles>

(b)

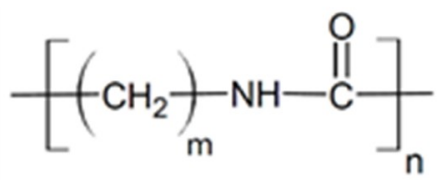

(d)

Figure 7. Chemical structure of (a) Polylactic acid (PLA), (b) Polyhydroxyalkanoate (PHA), (c) Poly butylene succinate (PBS), (d) Polyamide (PA). Adapted from [120-123].

\subsubsection{Bio-Based Thermosets}

The raw material for bio-based thermosets can be in the form of oil or other liquids extracted from diverse plants and animals. For example, verity thermoset resins are oil derived from fish, corn, soybean, cashew nutshell, linseed, etc. [124]. Thermosetting bioresins can be divided into epoxy, phenolic, polyurethane, polyester, and other resins. Table 5 presents a few thermoset bioresins available commercially on a large scale for industrial applications, and the bio-based content can be varied from $18 \%$ to $50-90 \%$ in them.

Table 5. Examples of few commercially available bio-based thermosets.

\begin{tabular}{|c|c|c|c|}
\hline Resin Type & Resin Base & Trade Name & Ref. \\
\hline Unsaturated polyester & Soybean oil & Ashland's Envirez & [124] \\
\hline $\begin{array}{l}\text { Acrylated epoxidized } \\
\text { soybean oil (AESO) }\end{array}$ & Soybean oil & Ebecryl 860 & [125] \\
\hline Epoxidized soybean oil & Soybean oil & Vikoflex 7170 & [126] \\
\hline $\begin{array}{l}\text { Epoxidized pine and } \\
\text { vegetable oils }\end{array}$ & Pine and vegetable oils & Super Sap 100 Epoxy & [126] \\
\hline Epoxidized linseed oil & Linseed oil & Vikoflex 7190 & [126] \\
\hline Acrylate functional resin & Soya oil & Cognis Tribest & [125] \\
\hline Natural phenols & $\begin{array}{l}\text { Distilled from forest } \\
\text { industry waste stream }\end{array}$ & Amroy Europe Oy EpoBioX ${ }^{\mathrm{TM}}$ & [124] \\
\hline Furfuryl alcohol-based resins & Biomass & $\begin{array}{l}\text { TransFurans Chemicals bvba } \\
\text { BioRez }{ }^{\mathrm{TM}} \text { furfuryl resin }\end{array}$ & [124] \\
\hline Alkyl phenolic oil & Cashew nut & CNSL & [126] \\
\hline
\end{tabular}

- $\quad$ Epoxy resins 
Epoxy resins are one of the most functional thermosetting polymers often synthesized by the reaction of polyols, polyphenols, or other active hydrogen compounds with epichlorohydrin [127]. Thermosetting epoxy resins can provide various properties depending on the curing agents and proportions, curing cycles, and additives added during their production [128]. Tensile strength for epoxies is in the range of 90-120 MPa, and the tensile modulus ranging from 3100 to $3800 \mathrm{MPa}$ [129]. According to their $\mathrm{Tg}$, which varies from 150 to $220^{\circ} \mathrm{C}$ (for uncured epoxies), they are the first or second common resin systems in aerospace. Apart from the properties mentioned above, epoxy resins' main drawbacks are their brittleness, moisture sensitivity, and recycling difficulty $[129,130]$. Since most of the conventional epoxy resins are strongly dependent on fossil sources and also their raw materials are hazardous for human health and the environment (such as diglycidyl ether bisphenol A (DGEBA)), a significant amount of research is dedicated to finding more environmentally friendly epoxies [131,132]. In this regard, after high demand for green industries, thermosetting bio-based epoxies such as natural oil-based epoxies, isosorbide-based epoxies, furan-based epoxy systems, phenolic and polyphenolic epoxies, as well as epoxy lignin derivatives, have been introduced in recent years [133].

\section{- $\quad$ Phenolic resins}

Phenolic resins are one of the favorable thermoset polymers that retain their industrial and commercial interest a century after their introduction due to their appropriate characteristics, such as superior mechanical strength, heat resistance, infusibility, flame retardancy, dimensional stability, as well as high resistance against numerous solvents, acids, and water [134]. They have been widely utilized in the manufacture of wood products, molded plastics, and aerospace components. Phenolic resins are prepared by the reaction of formaldehyde $(\mathrm{F})$ with phenol $(\mathrm{P})$. They can be synthesized in both acidic and alkaline environments depending on the F:P molar ratio, either acid-catalyzed resins (called Novolacs) $(0.75<$ F:P ratio < 0.85) or alkaline-catalyzed resins (called Resoles) (F:P ratio > 1.0) [135]. Recently, many attempts have been made to replace petroleum-based phenolic resins with bio-based phenolic products from biomass feedstock by liquefaction and pyrolysis process [136,137]. The U.S. National Renewable Energy Laboratory (NREL) has reported that it is possible to produce phenolic resins from wood rather than fossil fuels with about half the cost [138]. The principal chemical compounds of biomass are cellulose, hemicellulose, and lignin. Forestry residues/wastes that contain $40-45 \%$ cellulose, $15-35 \%$ hemicellulose, and $20-35 \%$ lignin would be valuable resources for bio-based phenolic resins $[139,140]$.

\section{- Polyester resins}

Polyester resins are the most economical resin systems utilized in engineering applications, particularly in the maritime and automotive industries [141,142]. Polyester is a viscous liquid resin produced by a condensation reaction between a glycol and an unsaturated dibasic acid. It is consists of a double bond between its carbon atoms $(C=C)$ and is recognized by clear pale yellow color [143]. Unsaturated polyester resins (UPRs), which are vital cross-linkable polymeric materials, are extensively used as a matrix for fiber-reinforced composites in a broad range of engineering applications such as construction, automotive, marine, electrical, decorative, and aerospace industry [144,145]. They have the right balance of mechanical, thermal, electrical, and chemical resistant properties, easy processability, low density, and low cost $[146,147]$. Plant oils are the primary choice between all biomass-derived feedstocks to prepare UPRs with renewable resources, owing to their abundance, low toxicity, biodegradability, and triglyceride structures appropriate for further chemical modification $[148,149]$. There is a growing interest in incorporating natural oils or their derivatives into UPR, aiming to fabricate novel structural bioplastics. For example, Mehta et al. [150] used methyl ester of soybean oil and epoxidized methyl linseedate (EML) to produce biocomposites containing the modified UPR. Das et al. [151] developed novel biomaterials through blending UPR with tung oil with improved impact strength. 


\section{Mechanical Properties of Hybrid Biocomposites}

Mechanical properties of hybrid biocomposites may depend on various features such as reinforcements and matrix mechanical properties, reinforcements dispersion and distribution, reinforcements volume fractions and aspect ratio, interfacial adhesion between polymer and reinforcements, loading and test conditions, fibers dimension and orientation, as well as surface modification $[16,152-156]$. In the following sections, some of the mechanical properties of recently developed hybrid biocomposites are reviewed.

\subsection{Strength (Tensile, Flexural, Impact)}

Mechanical testing, such as tensile, flexural, and impact tests, is the most common investigated hybrid biocomposites feature. The tensile strength of fiber-reinforced biocomposites generally increases with fiber content, up to optimum value, then will drop. This is due to the much higher strength and stiffness values of fibers than polymeric matrices [157-159]. When the natural fibers are introduced to the hydrophobic polymer matrices, their hydrophilic nature contrasts with matrices that induce high water absorption and subsequently result in low tensile strength of biocomposites. The surface treatment is a crucial solution to modify the fiber hydrophobicity and interfacial interaction of fiber/matrix, leading to improved tensile properties [160-162]. The longitudinal tensile modulus follows the linear rule of mixtures in the hybrid biocomposites, as many researchers have reported [35,75,163-165].

Impact resistance is another vital property of hybrid biocomposites, which is strongly related to toughness. It can be identified by energy absorption during a penetration impact, residual properties after impact, and damaged area after a nonpenetration impact. Moreover, dispersion and positioning of layers in hybrid biocomposites layup are known to be essential parameters for impact [166]. Laminated composites are the most common manufactured configuration among the various composites' structures. Figure 8 presented a few samples of the recent hybrid biocomposites with laminated design and different stacking sequences of layers. According to these configurations and other reported results [167-172], positioning of fibers with the highest energy-absorption on the outside layer rather than inside allows the hybrid composite to absorb more energy and achieve higher penetration impact resistance consequently. Furthermore, a higher degree of dispersion demonstrated better penetration impact resistance due to the smaller delaminated area and higher interfaces between distinct layers that absorb more energy [173-175]. Impact performance is also sensitive to interfacial adhesion between fiber and matrix [53]. The low adhesion in natural fiber-reinforced composites (NFRCs) and the load transfer between fiber and matrix would be improved by hybridization with synthetic fibers. In contrast, even synthetic reinforcements such as carbon fibers need to increase their surface energy by surface modifications to ensure the proper adhesion with matrices [176]. 

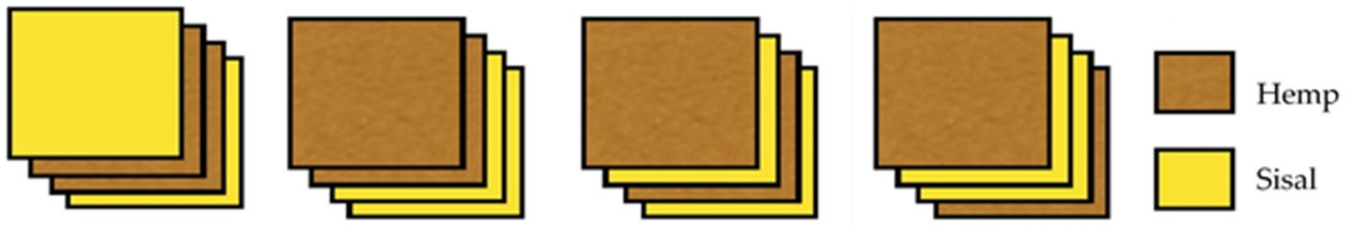

(a)
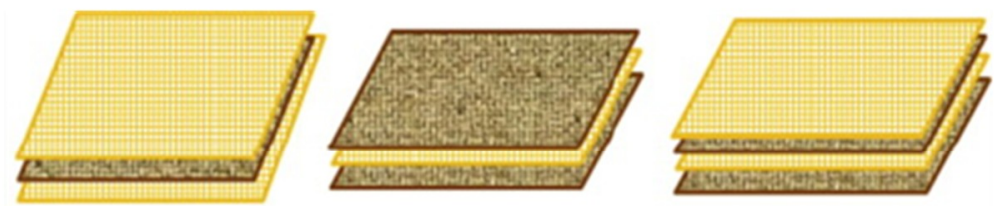

Kenaf

Kevlar

(b)

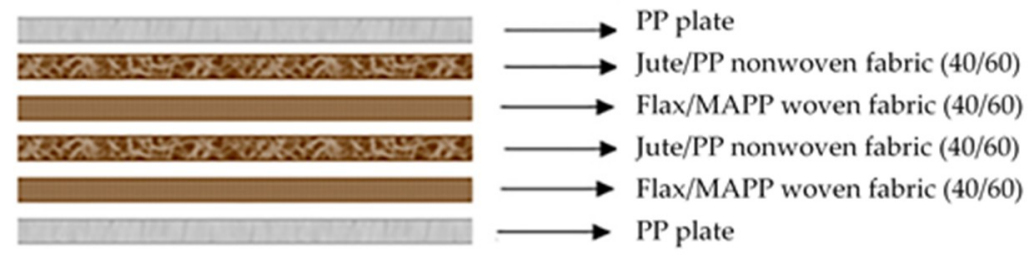

(c)

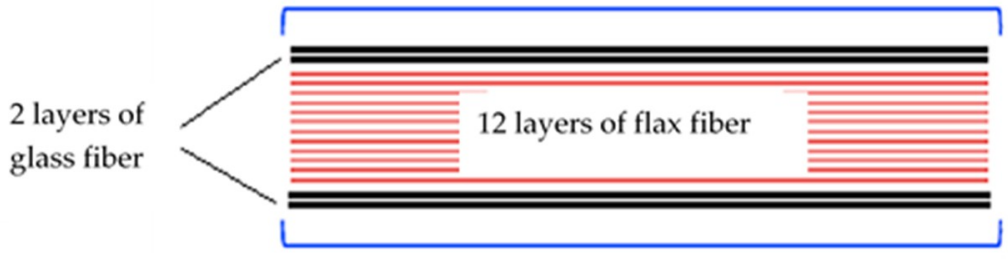

(d)
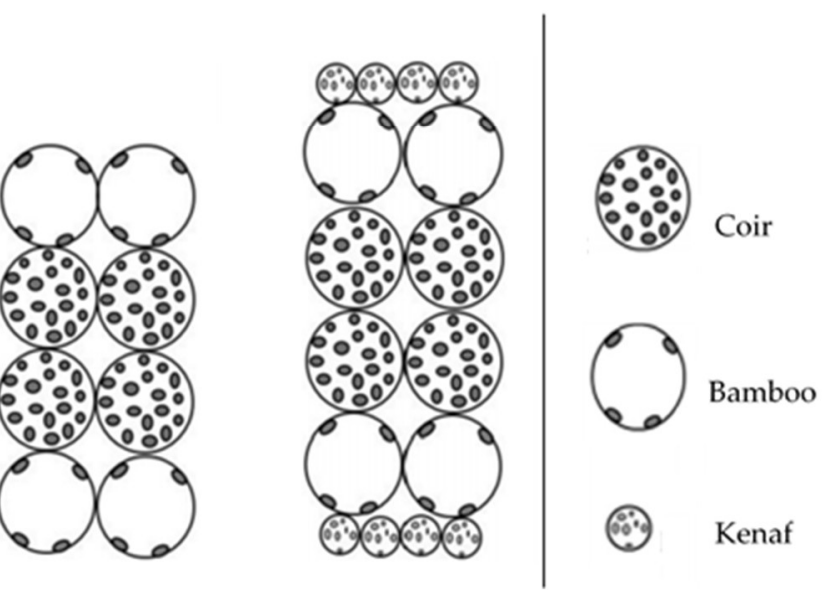

Figure 8. Different stacking configurations of some laminated hybrid biocomposites: (a) Hemp/sisal/epoxy. Adapted from [177], (b) Kenaf/kevlar/epoxy. Adapted from [178], (c) Jute/flax/ Polypropylene (PP). Adapted from [179], (d) Glass/flax/epoxy. Adapted from [180], (e) Coir/kenaf/epoxy, bamboo/coir/epoxy and kenaf/bamboo/coir/epoxy. Adapted from [181].

The flexural properties of hybrid composites, which reflect the laminate stiffness and dimensional constancy, are more difficult to understand than tensile properties [81]. The flexural strength and modulus are strongly dependent on the layup, as the longitudinal stress increases by moving away from the neutral line. Besides, changing the ply angles, material type, and stacking sequences of fibers can alter the flexural properties [166,182]. 
As mentioned earlier, the impact properties of polymeric materials depend essentially on the toughness of them. The material's toughness can be referred to as the material's capability to absorb the dynamic impact energy [183]. Natural fiber-based composites have desired interfacial properties and can dissipate a large amount of dynamic impact energy through the breakage and pull out the fibers. Moreover, hybridization of natural fiber composites with synthetic fibers is an effective technique to improve mechanical properties, especially the toughness [184]. Glass fibers-the most common synthetic fibers for hybridization of natural fibers-have high mechanical strength and good mechanical interlocking with hydrophobic matrices [185]. The most effective routes for hybridization of glass and natural fibers are (i) effective dispersion of short glass fibers with small loading into the bulk of short natural fibers, and (ii) laminated hybrid composite with glass fibers plies as an external skin and natural fibers as core laminates [186]. For example, in the glass/hemp hybrid composite, higher impact damage tolerance and toughness can be obtained using $11 \mathrm{vol} \%$ of glass fibers to reinforce the skin of hemp fibers composites due to superior stiffness and bending strength of glass fibers [187]. Another example is employing the small loading of glass fibers (up to $8.6 \mathrm{wt} \%$ ) in alkali-treated sisal fibers and pineapple leaf fibers (PALF) to improve the toughness and impact strength (up to $87 \%$ ) of hybrid composites [188]. Furthermore, it has been reported that the delamination fracture toughness of the glass/silk hybrid composite can be enhanced by placing the silk fabrics in the middle of the laminate composite to hinder the propagation of crack and control the crack delamination through the bending process [189]. The toughness of composites also depends on the fabrication method. Among the various techniques to improve interlaminar fracture toughness, through-the-thickness stitching is a promising technique using reinforcements at out of plane directions. In this technique, the composite can be fabricated by (i) reinforcement of un-cured pre-preg (pre-impregnated) laminates in the direction of a thickness (Z-pinning technique) (Figure 9a), and (ii) employment of dry fabric preforms that already includes the through-thickness reinforcement before the resin infusion (stitching). Modified lockstitch, lockstitch, and chain stitch are commonly used stitching techniques (Figure 9b-d) [190-193]. As for the weave preform, the best structural arrangement is the twill weave fabric due to its having the highest impact strength, which results in higher required force to pull out or break the fibers [194]. Moreover, incorporating nano and micro fillers has significant effects on the fracture properties of multi-scale composites. Nano and micro fillers contribute to toughening mechanisms by bridging micro-cracks and slowing down the crack initiation and crack growth. The average weight fraction required to enhance the composites' toughness and mechanical properties is in the range of 0.1-10 wt $\%$ and 10-50 wt \% for the nano and micro-fillers, respectively [195-198]. Recently, Zhang et al. [199] reported robust laminated biocomposites with improved mechanical strength and toughness. Figure 10 shows how a bridging structure is formed between alternating layers of chiral nematic cellulose nanocrystal $(\mathrm{CNC})$ and random cellulose nanofiber $(\mathrm{CNF})$ phase. This configuration would be useful when there are ductile and brittle phases in the composite. The more ductile material (CNF) has a mechanical buffering performance with the alternating sequence of layers. It prevents the initiation and propagation of cracks within the brittle material (CNC). Moreover, the ductile CNF layers provide strong hydrogen bonding networks with brittle CNC layers that optimize load transferring between brittle and ductile layers and improve strength and toughness. This manufactured biocomposite increases damage-tolerant property for soft-robotics and colorimetric sensors. Table 6 summarized the recent signs of progress on the mechanical properties of hybrid biocomposites. 


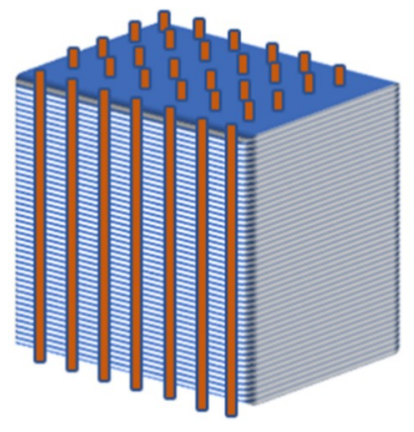

(a)

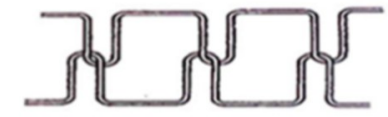

(b)

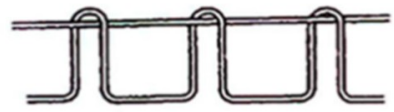

(c)

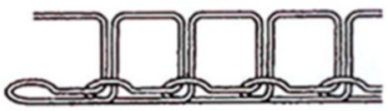

(d)

Figure 9. Different reinforcement stitching techniques: (a) Z-pinning [CMB, JA, MAM_UC3M2020], (b) lockstitch, (c) modified lockstitch, (d) chain stitch. Adapted from [200].

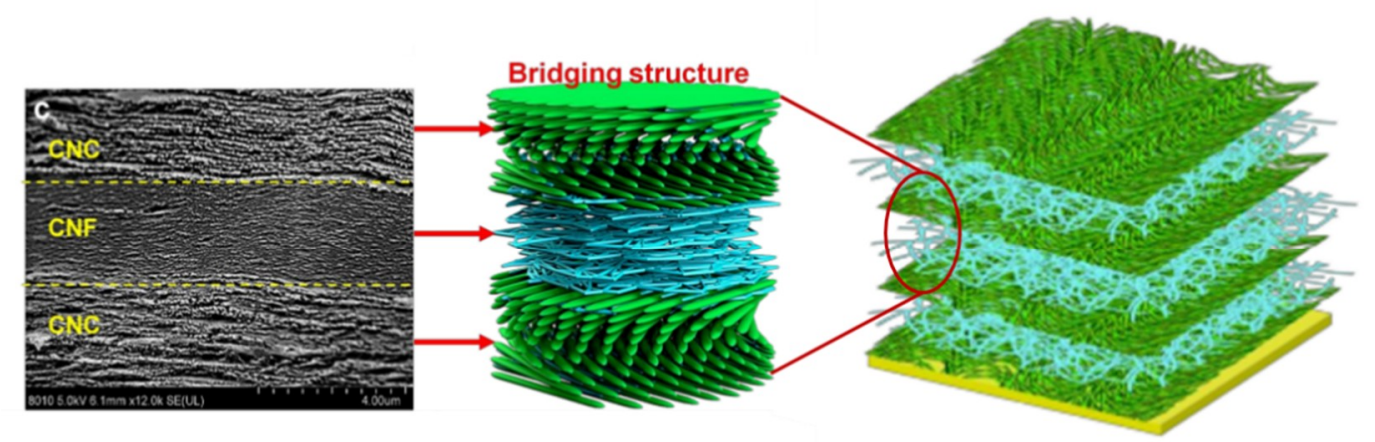

Figure 10. Schematic of chiral nematic cellulose nanofiber/random cellulose nanofiber (CNC-CNF) biocomposite with an alternating sequence of layers and corresponding SEM image of layers. Adapted from [199]. 
Table 6. Mechanical properties of recently developed hybrid biocomposites.

\begin{tabular}{|c|c|c|c|c|}
\hline Matrix & Fibers & Manufacturing Process and Conditions & Mechanical Properties & Ref. \\
\hline $\begin{array}{l}\text { Vinyl ester/unsaturated } \\
\text { polyester }\end{array}$ & Bagasse/henequen & $\begin{array}{c}\text { Hand lay-up } \\
\text { Alkali treatment }(5 \% \mathrm{NaOH}) \\
\text { Fiber length }=2 \mathrm{~cm}\end{array}$ & $\begin{aligned} \mathrm{TS}^{1} & =150 \mathrm{MPa} \\
\mathrm{FS}^{2} & =159 \mathrm{MPa} \\
\mathrm{IS}^{3} & =335 \mathrm{~J} / \mathrm{m}\end{aligned}$ & [201] \\
\hline $\begin{array}{l}\text { Epoxy resin (EpoxAmite 100) } \\
\text { modified with multi-walled } \\
\text { carbon nanotube (MWCNTs) }\end{array}$ & $\begin{array}{c}\text { Flax/carbon (FLXC) } \\
\text { Flax/glass (FLXG) } \\
\text { Flax/Kevlar (FLXK) }\end{array}$ & $\begin{array}{l}\text { Mechanical stirring and hand lay-up } \\
\text { Dispersing agent: dimethyl ketone ( } 2 \\
\text { propanone) with } 1 \mathrm{wt} \% \mathrm{CNT}\end{array}$ & $\begin{array}{c}\text { Improvement of tensile properties with } 1 \mathrm{wt} \% \mathrm{CNT} \\
\mathrm{TS}_{\mathrm{FLXC}}=340.13 \mathrm{MPa} \\
\mathrm{TS}_{\mathrm{FLXK}}=216.23 \mathrm{MPa} \\
\mathrm{TS}_{\mathrm{FLXG}}=114.82 \mathrm{MPa}\end{array}$ & [154] \\
\hline PLA & PALF/coir fiber $(\mathrm{CF})$ & $\begin{array}{l}\text { Hot press } \\
\text { Fiber loading: } 30 \mathrm{wt} \% \\
\text { CF:PALF }=1: 1\end{array}$ & $\begin{array}{c}\text { Hybrid composite of C1P1 (15\% CF } 115 \% \text { PALF) } \\
\text { showed better mechanical properties respect to } \\
\text { single fiber composites } \\
\text { TM }{ }^{4}=4.75 \mathrm{GPa} \\
\text { TS }=19.15 \mathrm{MPa} \\
\mathrm{FM}^{5}=4.86 \mathrm{GPa} \\
\mathrm{FS}=33.04 \mathrm{MPa} \\
\mathrm{IS}=4.24 \mathrm{~kJ} / \mathrm{m}^{2}\end{array}$ & [202] \\
\hline Epoxy resin & $\begin{array}{l}\text { Napier/carbon } \\
\text { Napier/glass }\end{array}$ & $\begin{array}{c}\text { Vacuum infusion } \\
\text { Napier:carbon and Napier:glass }=30: 0,24: 6, \\
18: 12,12: 18,6: 24\end{array}$ & $\begin{array}{c}\text { Increase of carbon and glass vol fraction increased } \\
\text { the flexural properties (max at 6:24\% vol) } \\
\text { FS: } \\
\text { Napier/carbon biocomposites }=456.31 \mathrm{MPa} \\
\text { Napier/glass biocomposites }=124.94 \mathrm{MPa} \\
\text { FM: } \\
\text { Napier/carbon biocomposites }=25.76 \mathrm{GPa} \\
\text { Napier/glass biocomposites }=13.15 \mathrm{GPa}\end{array}$ & [203] \\
\hline PLA & $\begin{array}{l}\text { Kenaf/coir (KCCK) Bamboo/coir } \\
\text { (BCCB) } \\
\text { Kenaf/bamboo/coir (KBCCBK) }\end{array}$ & Hot press & $\begin{array}{c}\text { TS of KBCCBK = } 187 \mathrm{MPa}(20 \text { and } 78 \% \text { higher than } \\
\text { BCCB and KCCK) } \\
\text { FS of KBCCBK and BCCB = } 199 \mathrm{MPa}, 206 \mathrm{MPa}(16 \% \\
\text { and } 20 \% \text { higher than KCCK) } \\
\text { FM of KCCK }=15 \mathrm{GPa} \text { ( } 70 \% \text { higher than others) }\end{array}$ & [181] \\
\hline $\begin{array}{l}\text { EpoxAmite } 100 \text { with MWCNTs } \\
\text { as a nanofiller }\end{array}$ & $\begin{array}{l}\text { FLXC } \\
\text { FLXG }\end{array}$ & $\begin{array}{c}\text { Wet lay-up } \\
1 \mathrm{wt} \% \text { concentration of MWCNT }\end{array}$ & $\begin{array}{l}\text { Better impact properties and higher compressive } \\
\text { strength of FLXG compared to FLXC }\end{array}$ & [204] \\
\hline Vinyl ester (VE) & PALF/glass & $\begin{array}{l}\text { Automated spray up } \\
\text { Vol. ratio of fibers }=50 / 50\end{array}$ & $\begin{array}{l}\text { TS (71.86 MPA) increased by } 171 \% \text { compared to } \\
\text { PALF-VE composite } \\
\text { FS (146.60 MPA) increased by } 164.66 \% \text { compared to } \\
\text { PALF-VE composite }\end{array}$ & [205] \\
\hline
\end{tabular}


Table 6. Cont

\begin{tabular}{|c|c|c|c|c|}
\hline Matrix & Fibers & Manufacturing Process and Conditions & Mechanical Properties & Ref. \\
\hline PLA-g-GMA & Agave fibers/nanoclay particles & $\begin{array}{l}\text { Extrusion } \\
\text { Compatibilizer: glycidyl methacrylate } \\
\text { (GMA) }\end{array}$ & $\begin{array}{l}\text { Using GMA caused an increment in TS and FS } \\
\text { Nanoclay particles improved the tensile and flexural } \\
\text { properties of the biocomposite }\end{array}$ & [206] \\
\hline PLA & $\begin{array}{l}\text { Alkali treated sisal and coir } \\
\text { fibers (ASF and ACF) }\end{array}$ & $\begin{array}{l}\text { Compression molding } \\
\text { Sisal:coir ratio }=7: 3\end{array}$ & $\begin{array}{c}\text { IS increased by } 22.8 \% \text { to PLA/ASF } \\
\text { FS improved ( } 92.6 \mathrm{MPa}) \\
\text { Decline of TS }\end{array}$ & [207] \\
\hline PLA & $\begin{array}{l}\text { Treated Kenaf fiber } \\
(\mathrm{TKF}) / \text { montmorillonite clay } \\
\text { (MMT) }\end{array}$ & $\begin{array}{l}\text { Screw extruder and compression molding } \\
\text { Alkali treatment ( } 6 \% \text { NaOH) Composition: } \\
\text { 30TKF-1MMT-69PLA }\end{array}$ & $\begin{array}{l}\text { FS and TS are improved by } 46.41 \% \text { and } 5.87 \% \text { than } \\
\text { PLA/TKF }\end{array}$ & [208] \\
\hline $\begin{array}{l}\text { Epoxy polymer (RenLam M- } 1 \\
\text { and Hardener HY 951) }\end{array}$ & $\begin{array}{l}\text { Sisal/glass/portland cement } \\
\text { particles }\end{array}$ & $\begin{array}{c}\text { Hand lay-up } \\
\text { Fiber-matrix mass fraction: 30/70 } \\
\text { Stacking sequence: five layers of sisal/glass } \\
\text { and glass/sisal }\end{array}$ & $\begin{array}{l}\text { Increase of FS due to the cement microparticles and } \\
\text { appropriate stacking sequence }\end{array}$ & [209] \\
\hline PHB & $\begin{array}{l}\text { Woven kenaf bast fiber } \\
(\mathrm{KBFw}) / \text { oil palm empty fruit } \\
\text { bunches (EFB) }\end{array}$ & $\begin{array}{l}\text { Lamination and compression molding } \\
\text { Plasticizer: triethyl citrate (TEC). } \\
\text { Arrangement: } 11 \text { layers (3KBF, 2EFB, } 6 \mathrm{PHB})\end{array}$ & $\begin{array}{l}\text { 11-layer hybrid composite with improved } \\
\text { mechanical properties can be an alternative for some } \\
\text { woody products } \\
\text { TS }=53.3 \mathrm{MPa} \\
\text { TM }=5.4 \mathrm{GPa} \\
\mathrm{FS}=77.90 \mathrm{MPa} \\
\mathrm{FM}=7.3 \mathrm{GPa} \\
\mathrm{IS}=40.6 \mathrm{~J} / \mathrm{m}\end{array}$ & [210] \\
\hline Epoxy resin & PALF/coir & $\begin{array}{l}\text { Hand lay-up molding } \\
\text { Application environment: natural soil } \\
\text { Fiber/resin ratio }=40: 60\end{array}$ & $\begin{array}{l}\text { Decrease of mechanical strength of hybrid } \\
\text { composites in burial condition compared to the pure } \\
\text { PALF-Epoxy composite }\end{array}$ & [211] \\
\hline Polyester resin & Bamboo/PLF/coir & $\begin{array}{l}\text { Hand lay-up followed by hot compression } \\
\text { molding } \\
\text { Fibers loading: } 45 \%, 30 \% \text { and } 15 \% \text { vol } \\
\text { Bamboo:PLF:coir }=15: 15: 15,10: 10: 10 \text { and } \\
5: 5: 5\end{array}$ & $\begin{array}{c}\text { Higher mechanical strength of hybrid composite } \\
\text { with } 45 \% \text { vol fibers loading compared to the single } \\
\text { fiber-reinforced composites } \\
\text { TS: } 136 \mathrm{MPa} \\
\text { FS: } 93 \mathrm{KN}\end{array}$ & [212] \\
\hline Unsaturated polyester & Sugar palm yarn/glass & $\begin{array}{l}\text { Sheet molding process and hot press } \\
\text { Resin/fiber ratio }=70: 40 \mathrm{wt} \% \\
\text { Sugar palm yarn:glass ratio }=50: 50 \mathrm{wt} \%\end{array}$ & $\begin{array}{l}\text { TS, TM, FS, FM, and IS of the hybrid composites } \\
\text { increased with increasing glass fiber loadings }\end{array}$ & [213] \\
\hline polypropylene & PALF/banana & $\begin{array}{c}\text { Compression molding } \\
\text { Chemically treatment with } 5 \% \mathrm{NaOH} \\
\text { Fiber loading: } 2,5,10 \text { and } 15 \mathrm{wt} \% \\
\text { PALF/banana ratio }=3: 1,1: 1 \text { and } 1: 3\end{array}$ & $\begin{array}{c}\text { The hybrid biocomposite with } 5 \mathrm{wt} \% \text { fibers loading } \\
\text { and PALF/banana ratio of 3:1 exhibited the best set } \\
\text { of mechanical properties }\end{array}$ & [214] \\
\hline
\end{tabular}


Table 6. Cont

\begin{tabular}{|c|c|c|c|c|}
\hline Matrix & Fibers & Manufacturing Process and Conditions & Mechanical Properties & Ref. \\
\hline polyurethane & Sugar Palm/glass & $\begin{array}{c}\text { Melt compounding and hot pressing } \\
\text { molding process } \\
\text { Chemical treatment: } 6 \mathrm{wt} \% \text { alkaline }+2 \mathrm{wt} \% \\
\text { silane solution }\end{array}$ & $\begin{array}{c}\text { The TS, FS, and IS of a hybrid composite improved } \\
\text { by } 16 \%, 39 \% \text {, and } 18 \% \text {, respectively, after the } \\
\text { chemical treatment }\end{array}$ & [215] \\
\hline Phenol formaldehyde & $\begin{array}{l}\text { Areca fine }(\mathrm{AF}) / \text { calotropis } \\
\text { gigantea }(\mathrm{CG})\end{array}$ & Hand lay-up & $\begin{array}{l}\text { Composite with } 17.5 \mathrm{wt} \% \mathrm{CG} \text { and } 17.5 \mathrm{wt} \% \mathrm{AF} \\
\text { fiber had maximum tensile, flexural, and impact } \\
\text { properties }\end{array}$ & [216] \\
\hline $\begin{array}{l}\text { Linear low-density } \\
\text { polyethylene (LLDPE) }\end{array}$ & $\begin{array}{l}\text { Sugarcane bagasse (SB)/eggshell } \\
\text { (Es) }\end{array}$ & $\begin{array}{l}\text { Compression molding } \\
\text { Fibers treated with titanium (IV) } \\
\text { isopropoxide and silane coupling agent }\end{array}$ & $\begin{array}{l}\text { TM and FM of the composites with treated fibers } \\
\text { were higher than untreated fibers } \\
\text { Improvement of TM and FM with increasing of filler } \\
\text { content up to } 20 / 20 \text { wt } \% \\
\text { The TS, FS, and IS tended to decrease with } \\
\text { increasing SB/Es content }\end{array}$ & [217] \\
\hline Phenol formaldehyde resin & $\begin{array}{l}\text { Areca/sisal } \\
\text { Areca/glass } \\
\text { Areca/roselle }\end{array}$ & $\begin{array}{c}\text { Hand lay-up } \\
\text { Divinylbenzene cross-linking agent }\end{array}$ & $\begin{array}{c}\text { Areca/sisal hybrid biocomposites presented the } \\
\text { highest TS and TM than others } \\
\text { FS and FM increased by hybridization of sisal, } \\
\text { roselle, and glass fibers with areca }\end{array}$ & [218] \\
\hline Thermoplastic SPS/agar (TPSA) & Sugar palm starch (SPS) & Hot press & The TS and FS slightly improved, but the IS reduced & [219] \\
\hline Polyurethane foam & $\begin{array}{l}\text { Roselle fiber (RF) with spherical } \\
\text { silica (silica-A) and amorphous } \\
\text { silica (silica-B) }\end{array}$ & Liquid molding & $\begin{array}{l}\text { FM increased with increasing wt } \% \text { of silica-A and } \\
\text { silica-B } \\
\text { TS increased with the increasing of silica-B and RF } \\
\text { Adding silica-A up to } 0.75 \mathrm{wt} \% \text { also increased TS }\end{array}$ & [220] \\
\hline Epoxy & $\begin{array}{c}\text { Glass/Flax/Basalt (GFB) } \\
\text { Flax/Hemp/Basalt (FHB) } \\
\text { Glass/Hemp/Basalt (GHB) }\end{array}$ & $\begin{array}{l}\text { Vacuum infusion process } \\
\text { Stacking sequence: } \\
\text { GFB: GFBBFG } \\
\text { FHB: FHBBHF } \\
\text { GHB: GHBBHG }\end{array}$ & $\begin{array}{l}\text { Reinforcement volume: } 21-23 \% \\
\text { Flexural performance: GFB }>\text { FHB }>\text { GHB }\end{array}$ & [221] \\
\hline Polypropylene & Banana/Coir & $\begin{array}{c}\text { Twin-screw extruder and injection moulding } \\
\text { Fiber loadings }(\mathrm{CF} / \mathrm{BF} / \mathrm{PP}): 15 / 5 / 80,10 / 10 / 80, \\
\text { and } 5 / 15 / 80 \mathrm{wt} \%\end{array}$ & $\begin{array}{c}\text { Max strengths at Banana/Coir: } 15 / 5 \mathrm{wt} \% \\
\text { TS: } 31.3316 \mathrm{MPa} \\
\text { TM: } 760.29 \mathrm{MPa} \\
\text { FS: } 31.336 \mathrm{MPa} \\
\text { FM: } 762.326 \mathrm{MPa} \\
\text { IS: } 51.6 \mathrm{~J} / \mathrm{m}\end{array}$ & [222] \\
\hline
\end{tabular}


Table 6. Cont

\begin{tabular}{|c|c|c|c|c|}
\hline Matrix & Fibers & Manufacturing Process and Conditions & Mechanical Properties & Ref. \\
\hline Epoxy & Banana/Jute & $\begin{array}{c}\text { Hand lay-up } \\
\text { Banana/jute ratio }=7: 3\end{array}$ & $\begin{array}{l}\text { Better mechanical properties of the hybrid } \\
\text { composite compared to mono composites } \\
\text { TS: } 85.91 \mathrm{MPa} \\
\text { FS: } 151.3 \mathrm{MPa} \\
\text { FM: } 1.23 \mathrm{GPa} \\
\text { IS: } 484.54 \mathrm{~J} / \mathrm{m}\end{array}$ & [223] \\
\hline Epoxy & Banana/Kenaf & $\begin{array}{c}\text { Hand lay-up } \\
\text { Banana/kenaf ratio }=40: 60,45: 55,50: 50 \\
55: 45 \text { and } 60: 40\end{array}$ & $\begin{array}{c}\text { Better mechanical properties with the highest kenaf } \\
\% \text { : } \\
\text { TS: } 58 \mathrm{MPa} \\
\text { TM: } 0.28 \mathrm{GPa} \\
\text { FS: } 24 \mathrm{MPa} \\
\text { IS: } 15.81 \mathrm{~J}\end{array}$ & [224] \\
\hline Epoxy & Sisal/Jute & $\begin{array}{l}\text { Hand lay-up } \\
\text { Jute/sisal ratio }=1: 0,1: 3,1: 1 \text { and 0:1 }\end{array}$ & $\begin{array}{l}\text { Fiber loading of } 30 \mathrm{wt} \% \\
\text { Better mechanical properties of } 1: 1 \text { hybrid composite } \\
\text { TS: } 102.08 \mathrm{MPa} \\
\text { TM: } 2.03 \mathrm{GPa} \\
\text { FS: } 361.9 \mathrm{MPa} \\
\text { FM: } 17.5 \mathrm{GPa} \\
\text { IS: } 30.1 \mathrm{KJ} / \mathrm{m}^{2}\end{array}$ & [225] \\
\hline Polypropylene & $\begin{array}{l}\text { Sisal/Glass (SG) } \\
\text { Sisal/Carbon (SC) }\end{array}$ & $\begin{array}{l}\text { Single extrusion machine and press } \\
\text { consolidation } \\
\text { SG and SC ratio }=25 / 75,50 / 50,75 / 25 \mathrm{wt} \%\end{array}$ & $\begin{array}{c}\text { Hybrid composite of } 25 / 75 \mathrm{wt} \% \text { for both SC and SG } \\
\text { showed better mechanical properties: } \\
\text { TS: } 22.4 \mathrm{MPa} \\
\text { TM: } 3.65 \mathrm{GPa} \\
\text { FS: } 52.6 \mathrm{MPa} \\
\text { FM: } 4.51 \mathrm{GPa} \\
\text { The addition of sisal fiber to pure carbon composite } \\
\text { decreases mechanical properties }\end{array}$ & [226] \\
\hline Polypropylene & Coir/Coconut shell & $\begin{array}{l}\text { Twin screw extruder and injection moulding } \\
\text { Fiber/filler ratio }=1: 0,3: 1,1: 1,1: 3 \text { and } 0: 1\end{array}$ & $\begin{array}{l}\text { Reinforcement loading: } 20 \mathrm{wt} \% \\
\text { With a hybrid ration of 1:1, TS and TM increased } 8 \% \\
\text { and } 50 \% \text { compared to the references, respectively }\end{array}$ & [227] \\
\hline Epoxy & Kenaf/Kevlar & $\begin{array}{c}\text { Hand lay-up } \\
\text { Three types of kenaf fiber: woven, UD, mat }\end{array}$ & $\begin{array}{l}\text { Woven kenaf hybrid composite showed better } \\
\text { mechanical properties compared to UD }{ }^{6} \text { and mat } \\
\text { TS: } 145 \mathrm{MPa} \\
\text { TM: } 3.37 \mathrm{GPa} \\
\text { FS: } 100.3 \mathrm{MPa} \\
\text { IS: } 51.41 \mathrm{KJ} / \mathrm{m}^{2}\end{array}$ & [228] \\
\hline
\end{tabular}


Table 6. Cont

\begin{tabular}{|c|c|c|c|c|}
\hline Matrix & Fibers & Manufacturing Process and Conditions & Mechanical Properties & Ref. \\
\hline Epoxy & Hemp/Sisal & $\begin{array}{c}\text { Hot press } \\
\text { Different layering sequence of fibers }\end{array}$ & $\begin{array}{l}\text { The non-hybrid composites showed superior tensile } \\
\text { and flexural properties than the hybrid composite } \\
\text { due to the low compatibility of sisal/hemp fibers }\end{array}$ & [177] \\
\hline Epoxy & Kenaf/Kevlar & $\begin{array}{l}\text { Hand lay-up followed by compression } \\
\text { Treated woven kenaf with NaOH } \\
\text { Layering sequence: } 4 \text {-layer and 3-layer with } \\
\text { a different skin layer }\end{array}$ & $\begin{array}{c}\text { Reinforcement loading: } 30 \mathrm{wt} \% \\
\text { Mechanical properties of hybrid composite with } \\
\text { 4-layer improved: } \\
\text { TS: } 64.7 \mathrm{MPa} \\
\text { TM: } 5.29 \mathrm{GPa} \\
\text { FS: } 51.28 \mathrm{MPa} \\
\text { FM: } 2.74 \mathrm{GPa} \\
\text { IS: } 50.1 \mathrm{KJ} / \mathrm{m}^{2} \\
\text { Kevlar as a skin layer improved tensile and flexural } \\
\text { properties, but kenaf as a skin improved IS }\end{array}$ & [178] \\
\hline Epoxy modified with LENR ${ }^{7}$ & Kenaf/Glass & $\begin{array}{c}\text { Glass/kenaf ratio }=1: 1 \\
\text { Treatment of kenaf with } \mathrm{NaOH}\end{array}$ & $\begin{array}{c}\text { Fiber treatment and adding of LENR to the matrix } \\
\text { improved the mechanical properties: } \\
\text { FS: } 68.1 \mathrm{MPa} \\
\text { IS: } 13.1 \mathrm{KJ} / \mathrm{m}^{2} \\
\end{array}$ & [229] \\
\hline Polyester & Kenaf/Glass & $\begin{array}{c}\text { Hand lay-up and hydraulic cold press } \\
\text { Kenaf/glass ratio }=3: 7 \\
\text { Sandwich configuration with glass shell and } \\
\text { kenaf core } \\
\text { Three types of kenaf: non-woven random } \\
\text { mat, UD twisted yarn, plain-woven }\end{array}$ & $\begin{array}{l}\text { Reinforcement loading: } 35 \mathrm{wt} \% \\
\text { UD and woven fibers had higher tensile and flexural } \\
\text { properties, respectively: } \\
\text { TS: } 194.6 \mathrm{MPa} \\
\text { FM: } 291.6 \mathrm{MPa}\end{array}$ & [230] \\
\hline Epoxy & Jute/Glass & $\begin{array}{c}\text { Epoxy/jute/glass weight ratio }=69 / 31 / 0 \\
68 / 25 / 7 \text { and } 64 / 18 / 19\end{array}$ & $\begin{array}{c}\text { The addition of glass and jute fibers with a ratio of } \\
\text { 64/18/19 showed the highest mechanical properties: } \\
\text { TS: } 56.68 \mathrm{MPa} \\
\text { FS: } 28.81 \mathrm{MPa} \\
\text { FM: } 1.83 \mathrm{GPa} \\
\text { IS: } 5.49 \mathrm{~J}\end{array}$ & [231] \\
\hline Polyethylene & $\begin{array}{l}\text { Oil palm fiber (OPF) and clay } \\
\text { particles }\end{array}$ & $\begin{array}{l}\text { Extrusion and injection molding } \\
\text { Alkali treatment of OPF }\end{array}$ & $\begin{array}{c}\text { Reinforcement loading: } 25 \mathrm{wt} \% \\
\text { The 12.5:12.5 hybrid composite showed } 11 \% \text { and } \\
49 \% \text { improvement of tensile strength and modulus, } \\
\text { respectively }\end{array}$ & [232] \\
\hline
\end{tabular}


Table 6. Cont.

\begin{tabular}{|c|c|c|c|c|}
\hline Matrix & Fibers & Manufacturing Process and Conditions & Mechanical Properties & Ref. \\
\hline Epoxy & Sugar palm fiber (SPF)/Glass & $\begin{array}{c}\text { Hand lay-up } \\
\text { Benzoylation treatment on SPF } \\
\text { Glass fiber ratio: } 30 \%, 50 \% \text {, and } 70 \mathrm{wt} \%\end{array}$ & $\begin{array}{c}\text { Glass fiber ration of } 70 \mathrm{wt} \% \text { exhibited the best } \\
\text { tensile properties: } 55.7 \% \text { and } 50.5 \% \text { improvement of } \\
\text { TS and TM, respectively } \\
\text { Benzoylation treatment improved adhesion of } \\
\text { fibers/matrix }\end{array}$ & [233] \\
\hline Polypropylene & $\begin{array}{l}\text { Sisal fiber (SiF)/Cellulose } \\
\text { nanocrystals (CNC) }\end{array}$ & $\begin{array}{c}\text { Melt-blending followed by injection molding } \\
\text { SiF/CNC loading (29:1, 27:3, 25:5, and 23:7 wt } \\
\%)\end{array}$ & $\begin{array}{c}\text { Enhancement of matrix with MAPP }{ }^{8} \text { compatibilizer } \\
\text { Hybrid composite with SiF/CNC }(27: 3 \mathrm{wt} \%) \text { showed } \\
\text { highest TS }(47.02 \mathrm{MPa}), \mathrm{TM}(2.82 \mathrm{GPa}) \text { and IS } \\
(38.62 \mathrm{~J} / \mathrm{m}) \text { with } 30.87 \% \text { and } 14.81 \% \text { increment of FS } \\
\text { and FM respectively }\end{array}$ & [234] \\
\hline Epoxy & $\begin{array}{l}\text { Hemp/polyethylene } \\
\text { terephthalate (PET) }\end{array}$ & Vacuum-infusion & $\begin{array}{c}\text { The TS and FS of interwoven hemp/PET hybrid } \\
\text { composites were } 4 \% \text { and } 22 \% \text { greater than woven } \\
\text { hemp composites }\end{array}$ & [235] \\
\hline Epoxy & Flax/Glass & $\begin{array}{l}\text { Compression-molding machine } \\
\text { Sandwich structure: outer layers of } \\
\text { glass/epoxy and the core from Flax/Epoxy }\end{array}$ & $\begin{array}{l}\text { UD hybrid composite }\left[0_{\mathrm{G}} / 0_{\mathrm{F}}\right] \text { has a higher TS }(408.25 \\
\mathrm{MPa}), \mathrm{TM}(31.97 \mathrm{GPa}), \mathrm{FS}(591.25 \mathrm{MPa}), \text { and } \mathrm{FM} \\
(39.84 \mathrm{GPa}) \text { compared to angle ply }\left[0_{\mathrm{G}} / \pm 45_{\mathrm{F}}\right] \\
\text { hybrid composite and also flax/epoxy composite }\end{array}$ & [180] \\
\hline Epoxy & $\begin{array}{c}\text { Arenga pinnata fiber } \\
(\mathrm{APF}) / \text { polyester yarn }(\mathrm{PET})\end{array}$ & $\begin{array}{c}\text { Lay-up } \\
\mathrm{Mg}(\mathrm{OH})_{2} \text { as a flame retardant }(5 \mathrm{wt} \%) \\
\text { APF:PET ratio }=0: 5,20: 5,35: 5 \text { and } 50: 5 \mathrm{wt} \%\end{array}$ & $\begin{array}{l}\mathrm{Mg}(\mathrm{OH})_{2} \text { as a flame retardant } \\
\text { Hybrid composite with } 20 \mathrm{wt} \% \text { and } 35 \mathrm{wt} \% \text { APF } \\
\text { had the highest TM }(165.2 \mathrm{MPa}) \text { and TS }(9.69 \\
\left.\mathrm{N} / \mathrm{mm}^{2}\right) \text {, respectively } \\
\text { Increasing the fiber loading to the } 50 \mathrm{wt} \% \text { decreased } \\
\text { the tensile properties }\end{array}$ & [236] \\
\hline $\begin{array}{l}\text { Ethylene propylene diene } \\
\text { monomer (EPDM) rubber }\end{array}$ & $\begin{array}{c}\text { Kevlar fiber (KF)/Nano-silica } \\
\text { (NS) }\end{array}$ & $\begin{array}{l}\text { Roll milling followed by compression } \\
\text { molding }\end{array}$ & $\begin{array}{c}\text { TS, elongation-at-break, and TM values of EPDM } \\
\text { significantly increased by hybridization with KF and } \\
\text { NS: } \\
\text { TS: } 4.94 \mathrm{MPa} \\
\text { TM:51.09 MPa }\end{array}$ & [237] \\
\hline PLA & $\begin{array}{l}\text { Coir fiber }(\mathrm{CF}) / \mathrm{PALF} \\
\text { With alkaline treatment }\end{array}$ & $\begin{array}{l}\text { Internal mixer followed by compression } \\
\text { molding } \\
\text { CF:PALF ratios }=3: 7,1: 1 \text { and } 7: 3 \\
\text { Fibers loading: } 30 \mathrm{wt} \%\end{array}$ & $\begin{array}{c}\text { Hybrid composite with higher PALF, C3P7 (CF:PALF } \\
\text { = 3:7) exhibited the highest tensile properties: } \\
\text { TS: } 30.29 \mathrm{MPa} \\
\text { TM: } 5.16 \mathrm{GPa} \\
\text { However, the C1P1 hybrid composite presented the } \\
\text { highest IS }\end{array}$ & [238] \\
\hline
\end{tabular}

\footnotetext{
${ }^{1}$ Tensile strength; ${ }^{2}$ Flexural strength; ${ }^{3}$ Impact strength; ${ }^{4}$ Tensile modulus; ${ }^{5}$ Flexural modulus; ${ }^{6}$ Unidirectional $;{ }^{7}$ Liquid epoxidized natural rubber; ${ }^{8}$ Maleic anhydride grafted PP.
} 


\subsection{Water Absorption}

All green composites may absorb water in a humid atmosphere or when immersed in water. Natural fibers with a hydrophilic nature due to hydroxyl $(-\mathrm{OH})$ and other polar groups in their different constituents such as cellulose and hemicellulose are interested in absorbing water. This phenomenon leads to swelling of the fiber, degradation of a fiber-matrix interface, plasticizing effect, expansion of the gap between fiber bundles that reduces the load-transfer efficiency, and results in depletion of biocomposite performance and reduction of mechanical properties [239-241]. Accordingly, an inevitable step before using biocomposites in each application is analyzing the water absorption of the developed biocomposite. Water absorption in composites can be affected by fiber volume fraction, a viscosity of matrix, voids, humidity, and temperature [242]. Three various mechanisms govern water diffusion in green composites. The first one is the diffusion of water molecules inside the micro gaps of polymer chains. The next one is the capillary movement of water into the flaws and holes at the fiber-matrix interfaces. The last one is the initiation of microcracks in the matrix resulting from swelling of fibers or laminates [243-245]. Fibers' surface treatments as a solution approach to reduce the water uptake have attracted several researchers. Treatment techniques of reinforcement fibers can be generally classified into chemical and physical methods. The fiber's structural and surface properties are modified by employing physical modification methods, resulting in changing the mechanical bonding between the fiber matrix. Stretching, calendaring, and electric discharge with corona and cold plasma are some examples of physical modification methods [246-251]. Thermal treatment is another physical approach to modify water absorption property in biocomposites. It causes the fibers' moisture loss, increasing interfacial adhesion, and fiber stiffness due to the increased crystallinity [252,253]. It is noteworthy that the increase of fiber-matrix adhesion is a prerequisite for high strength and leads to lower water uptake [253]. Aging that is wet/dry cycling treatment and induces shrinkage and reduces the water retention values is an effective thermal treatment in this matter [16,254]. On the other hand, chemical modification techniques adjust the hydrophilic hydroxyl groups from the fiber surface based on reagent functional groups, reacting with functional groups in the fibers, and altering their compositions [44]. Various chemical treatments such as alkali, benzoylation, mercerization, silane, acetylation, isocyanate, acrylation, permanganate, peroxide treatment with multiple coupling agents, and bio-based coatings have been applied on fiber-reinforced biocomposites to reduce water absorption, improve fiber-matrix adhesion, and consequently enhance mechanical performance [57,241,253,255-259].

Another reported approach to increase the water-resistance of hybrid biocomposites is the integration of nanofillers. Three types of nanofillers have been used in researches to enhance the performance of composites (i) nanotubes, (ii) nanoparticles, and (iii) nanolayers. Nanofillers with a high aspect ratio can be made of metals, metal oxides, polymers, and carbon [260]. Ramesh et al. [261,262] worked on the hybridization of PLA/treated kenaf and PLA/treated aloevera biocomposite with montmorillonite (MMT) nanoclay. In both cases, adding the MMT nanoclay successfully increased the hybrid biocomposites performance, especially water resistance. This phenomenon is referred to as the barrier function of nanoclays, limiting the flow of water into biocomposite and reducing water absorption. Nanoclay particles, which are classified under silicate nanomaterials, are one of the most commonly utilized nanofillers. They can be added in composites with various forms, such as nanoclay platelets, calcinated nanoclay, and montmorillonite. Anbukarasi et al. [263] investigated the effect of $\mathrm{SiO}_{2}$ nanospheres fillers on the water absorption behavior of luffa-coir/epoxy hybrid composites. They concluded that the water absorption of the hybrid composite was significantly reduced by adding $\mathrm{SiO}_{2}$ nanospheres. These nanospheres fillers compensate for the fibers' hydrophilic effect by reducing the number of free hydroxyl groups of luffa and coir fibers. $\mathrm{SiO}_{2}$ nanoparticles have high strength and high specific surface area, which improves the mechanical properties of composites and enhance the interfacial adhesion between fibers and matrix [264]. Hasan et al. [265] evaluated the effects of halloysite nanotube (HNT) on epoxy/basalt hybrid biocomposites' durability. They reported adding two wt \% HNTs provides better interfacial bonding between fibers/matrix and decreases water 
absorption. Better water resistance is mostly due to the 1D morphology of the HNTs and their high aspect ratio, which restricts the diffusion of water molecules by means of a tortuous path.

Water adsorption would also be a desired property in applications in which high water intake is more favorable than mechanical properties such as tissue engineering, biomedical, and biotechnology. Superabsorbent polymer composites (SAPCs) or hydrogels are among the most well-known materials that require high water absorption capacity more than their dry mass [266]. Many researchers have recently reported novel synthetized biobased SAPCs [267-271] and hybrid hydrogel composites [267-270]. Only a few studies have been recently reported hybridization of hydrogels with fibers [271-273], and Table 7 is excluded from them because adding fibers in those cases is to modify other properties of hydrogel rather than water absorption. Table 7 lists the recent findings on the water absorption behavior of hybrid biocomposites. 
Table 7. Water absorption behavior of recently developed hybrid biocomposites.

\begin{tabular}{|c|c|c|c|c|c|}
\hline Matrix & Fibers & Manufacturing Process & Treatment & Water Absorption & Ref. \\
\hline PLA & Kenaf fiber and MMT clay & $\begin{array}{l}\text { Extrude, roll mill compression } \\
\text { molding }\end{array}$ & $\mathrm{NaOH}$ treatment & $\begin{array}{c}\text { Adding one wt } \% \text {, MMT decreased } \mathrm{WA}^{1} \text { due to } \\
\text { the barrier effects }\end{array}$ & {$[261]$} \\
\hline Green epoxy & Sisal/hemp & Hand lay-up and hot press & - & $\begin{array}{l}\text { Higher WA of hybrid composite }(12 \%) \text { than the } \\
\text { pure or non-hybrid composites }(7 \%)\end{array}$ & {$[177]$} \\
\hline PLA & Aloevera fiber and MMT clay filler & $\begin{array}{l}\text { Twin-screw extruder, two-roll } \\
\text { mill, and compression molding } \\
\text { method }\end{array}$ & $\mathrm{NaOH}$ treatment & $\begin{array}{l}\text { Hybridization increased WA Increasing MMT } \\
\text { content }(3 \mathrm{wt} \%) \text { maximized water-resistance of } \\
\text { hybrid biocomposite }\end{array}$ & {$[262$} \\
\hline Epoxy & Luffa/coir $/ \mathrm{SiO}_{2}$ nanospheres & $\begin{array}{l}\text { Conventional molding } \\
\text { Fiber loading: } 40 \text { vol } \% \\
\end{array}$ & $\mathrm{NaOH}$ treatment & $\begin{array}{l}\text { Decrease of WA to } 0.14 \% \text { by adding } 3 \mathrm{vol} \% \text { of } \\
\qquad \mathrm{SiO}_{2}\end{array}$ & {$[263$} \\
\hline polyester & $\begin{array}{c}\text { Jute/glass } \\
\text { Sisal/glass } \\
\text { Sisal/jute/glass } \\
\end{array}$ & Hand lay-up & $\begin{array}{c}\text { Treatment with succinic } \\
\text { anhydride and phthalic } \\
\text { anhydride }\end{array}$ & $\begin{array}{l}\text { Hybridization of JF and SF with glass fiber } \\
\text { reduced the WA content significantly }\end{array}$ & {$[274$} \\
\hline Epoxy resin araldite & Sisal/coir (1:1) & Cold pressing & - & $\begin{array}{l}\text { WA of hybrid composites increased with an } \\
\text { increase of fiber wt } \% \text { and soaking duration }\end{array}$ & {$[275]$} \\
\hline Epoxy Resin & pineapple/coir (1:1) & Hand lay-up & - & $\begin{array}{l}\text { Coir/pineapple/coir (CPC) pattern showed the } \\
\text { highest water resistance to PCP and P/C patterns }\end{array}$ & {$[276$} \\
\hline Isothalic polyester & Jute/glass & Hand lay-up & $\mathrm{UV}$ radiation treatment & $\begin{array}{c}\text { Improvement in water/moisture absorption } \\
\text { resistance }\end{array}$ & [29] \\
\hline $\begin{array}{l}\text { Liquid diglycidyl ether of } \\
\text { Bisphenol-A blended with } \\
\text { neem oil }\end{array}$ & Kenaf fiber and sea-urchin spike filler & Casting & $\begin{array}{c}\text { Amino silane surface } \\
\text { treatment }\end{array}$ & $\begin{array}{c}\text { Surface-modified kenaf fiber improved water } \\
\text { resistance } \\
\text { The addition of neem oil into epoxy did not } \\
\text { change WA }\end{array}$ & {$[277]$} \\
\hline Polypropylene & Sisal/glass & Injection molding & $\mathrm{NaOH}$ treatment & $\begin{array}{l}\text { The addition of } 10 \text { and } 20 \mathrm{wt} \% \text { glass fibers } \\
\text { showed improvement in water resistance }\end{array}$ & {$[278]$} \\
\hline Epoxy resin & $\begin{array}{l}\text { Hemp/jute } \\
\text { Hemp/flax } \\
\text { Hemp/jute } \\
\quad \text { /flax }\end{array}$ & $\begin{array}{l}\text { Hand lay-up compression } \\
\text { technique }\end{array}$ & - & $\begin{array}{c}\text { Hemp/jute/epoxy, hemp/jute/flax/epoxy and } \\
\text { hemp/flax/epoxy absorbed } 4.5 \%, 3 \% \text { and } 2.8 \% \\
\text { water respectively }\end{array}$ & {$[240]$} \\
\hline Low-density polyethylene & $\begin{array}{l}\text { Jute/bamboo (1:1) cellulose } \\
\text { Untreated jute/bamboo }\end{array}$ & Hot press & $\begin{array}{l}\text { Dewaxing, alkaline } \\
\text { treatment, and } \\
\text { mercerization }\end{array}$ & $\begin{array}{l}\text { Lower WA of treated cellulose hybrid } \\
\text { composites }(0.7 \%) \text { with ten wt } \% \text { fibers loading } \\
\text { respect to untreated fiber }\end{array}$ & {$[279]$} \\
\hline Starch-glycerol & $\begin{array}{l}\text { Jute with and without epoxy resin coating } \\
\text { (Araldite CY-230) }\end{array}$ & $\begin{array}{l}\text { Wet hand lay-up and } \\
\text { compression molding }\end{array}$ & $\begin{array}{l}\text { Treatment by alkaline } \\
\text { sodium hydroxide }\end{array}$ & $\begin{array}{l}\text { A thin coating of epoxy reduced the WA } \\
\text { significantly }\end{array}$ & {$[280]$} \\
\hline $\begin{array}{l}\text { Novolac type Phenolic } \\
\text { formaldehyde }\end{array}$ & PALF/kenaf & Hot press & $\begin{array}{l}\text { Triethoxy (ethyl) silane } \\
\text { treatment }\end{array}$ & $\begin{array}{c}\text { Treated hybrid composites revealed a reduction } \\
\text { in WA } \\
\text { 70P:30K ratio showed the lowest WA }\end{array}$ & {$[281]$} \\
\hline $\begin{array}{l}\text { Unsaturated polyester } \\
\text { (UP) blended epoxy }\end{array}$ & E-glass fiber and iron (III) oxide particles & Hand lay-up & $\begin{array}{l}\text { Amino-silane (APTMS) } \\
\text { treatment }\end{array}$ & $\begin{array}{l}\text { Low WA was observed for composites consist of } \\
5 \text { and } 10 \text { vol \% of UP into epoxy }\end{array}$ & {$[282$} \\
\hline
\end{tabular}


Table 7. Cont

\begin{tabular}{|c|c|c|c|c|c|}
\hline Matrix & Fibers & Manufacturing Process & Treatment & Water Absorption & Ref. \\
\hline Epoxy & Coir fiber with $\mathrm{Al}_{2} \mathrm{O}_{3}$ filler & $\begin{array}{c}\text { Hand-lay-up } \\
\text { Fiber loading: 5, 10, } 15, \text { and } 20 \mathrm{wt} \\
\% \\
\text { Filler loading: } 10 \mathrm{wt} \%\end{array}$ & - & $\begin{array}{l}\text { Amount of WA increased along with increasing } \\
\text { fiber loading and decreasing epoxy loading }\end{array}$ & {$[283$} \\
\hline $\begin{array}{l}\text { Thermoplastic SPS/agar } \\
\text { (TPSA) }\end{array}$ & Sugar palm starch (SPS) & Hot press & - & $\begin{array}{l}\text { Minimal improvement of water resistance } \\
\text { properties }\end{array}$ & {$[219]$} \\
\hline Epoxy LY 556 & Date Palm Leaf (DPL)/glass & Hand lay-up & Alkaline treatment & $\begin{array}{l}\text { The rate of WA of the composites increased by } \\
\text { adding more DPL fiber } \\
\text { Maximum water uptake in } 30 \mathrm{wt} \% \text { of DPL }\end{array}$ & {$[284$} \\
\hline Polypropylene & Banana/Coir & $\begin{array}{c}\text { Twin-screw extruder and } \\
\text { injection moulding } \\
\text { Fiber loadings (CF/BF/PP): } \\
\text { 15/5/80, 10/10/80, and 5/15/80 wt } \%\end{array}$ & - & $\begin{array}{l}\text { Increase of WA with an increase of soaking time } \\
\text { and coil wt } \%\end{array}$ & {$[222]$} \\
\hline Epoxy & Sisal/Jute & $\begin{array}{c}\text { Hand lay-up } \\
\text { Jute/sisal ratio }=1: 0,1: 3,1: 1 \text { and } \\
0: 1\end{array}$ & Alkaline treatment & $\begin{array}{l}\text { Fiber loading: } 30 \mathrm{wt} \% \\
\text { Lower WA of 1:1 hybrid composite due to the } \\
\text { better interfacial bonding of matrix/fibers }\end{array}$ & {$[225$} \\
\hline Epoxy & Kenaf/Kevlar & $\begin{array}{l}\text { Hand lay-up } \\
\text { Three types of kenaf fiber: woven, } \\
\text { UD, mat }\end{array}$ & - & Woven and UD kenaf absorbed less water & {$[228]$} \\
\hline Epoxy & Jute/Glass & $\begin{array}{c}\text { Epoxy/jute/glass weight ratio = } \\
69 / 31 / 0,68 / 25 / 7, \text { and } 64 / 18 / 19 \mathrm{wt} \\
\%\end{array}$ & - & $\begin{array}{l}\text { THE lowest WA was for hybrid composite with } \\
\text { a 64/18/19 ratio (11.7\% after } 1172 \mathrm{~h} \text { immersion in } \\
\text { water) }\end{array}$ & {$[231]$} \\
\hline Epoxy & Hemp/polyethylene terephthalate (PET) & Vacuum-infusion & - & $\begin{array}{l}\text { WA of the hemp/PET hybrid composite was half } \\
\text { of the woven hemp composites }\end{array}$ & {$[235$} \\
\hline Epoxy & Flax/Glass & $\begin{array}{c}\text { Compression-molding machine } \\
\text { Sandwich structure: outer layers } \\
\text { of glass/epoxy and the core from } \\
\text { Flax/Epoxy }\end{array}$ & - & $\begin{array}{l}\text { Hybrid composite of UD flax/glass/epoxy had a } \\
\text { lower WA (4.6\%) after } 40 \text { days to the } \\
\text { carbon/epoxy and carbon/flax/epoxy composites }\end{array}$ & {$[180]$} \\
\hline Vinyl ester & Flax/Basalt & $\begin{array}{c}\text { Vacuum-infusion } \\
\text { Fiber stacking sequence: BFFFFB }\end{array}$ & - & $\begin{array}{l}\text { Hybrid composite exhibited lower WA } \\
\text { compared to the flax/vinyl ester composite }\end{array}$ & {$[285]$} \\
\hline Epoxy & Sugar palm fiber (SPF)/Glass & $\begin{array}{c}\text { Hand lay-up } \\
\text { Glass fiber ratio: } 30 \%, 50 \% \text {, and } \\
70 \mathrm{wt} \%\end{array}$ & $\begin{array}{l}\text { Benzoylation treatment on } \\
\text { SPF }\end{array}$ & $\begin{array}{l}\text { Treated hybrid composite with } 50 \mathrm{wt} \% \text { glass } \\
\text { fiber exhibited min WA after } 2 \mathrm{~h}(0.16 \%)\end{array}$ & {$[233$} \\
\hline PLA & Coir fiber (CF)/PALF & $\begin{array}{l}\text { Internal mixer followed by } \\
\text { compression molding } \\
\text { CF:PALF ratios = 3:7, 1:1 and 7:3 }\end{array}$ & Alkaline treatment & $\begin{array}{c}\text { Fibers loading: } 30 \mathrm{wt} \% \\
\text { C7P3 (CF:PALF = 7:3) showed the lowest WA } \\
(5.24 \%) \text { after } 7 \text { days }\end{array}$ & {$[238$} \\
\hline PLA-g-GMA & Agave fibers/nanoclay particles & Extrusion & $\begin{array}{l}\text { Compatibilizer: glycidyl } \\
\text { methacrylate (GMA) }\end{array}$ & $\begin{array}{l}\text { Compatibilizing compensated the hydrophilic } \\
\text { character of agave fibers and decreased the WA }\end{array}$ & {$[206]$} \\
\hline Unsaturated polyester & Sugar palm yarn/glass & $\begin{array}{l}\text { Sheet molding process and hot } \\
\text { press }\end{array}$ & - & $\begin{array}{l}\text { Increasing the glass fiber content from } 30 \% \text { to } 50 \\
\text { wt } \% \text { improved WA properties }\end{array}$ & {$[213]$} \\
\hline
\end{tabular}




\subsection{Flame Retardancy}

One of the major drawbacks of biocomposites is their relatively poor resistance to burning. Most of the natural reinforcements and biopolymer (hemicellulose and lignin) are susceptible to fire and combustion. They undergo thermal decomposition at low temperatures $\left(200-300{ }^{\circ} \mathrm{C}\right)[286,287]$. Since natural reinforcements' flammability could limit their application in the automotive, aerospace, and construction industries, it is vital to adjust materials with more flame-resistant without compromising their good mechanical properties [27]. Recently, there has been more research on hybrid materials based on synthetic-natural fibers to manufacture more environmentally friendly composites. Many researchers reported that by incorporating synthetic fibers into the natural ones, it might be possible to increase the thermal stability and flame resistance of biocomposites. Some of these recent studies on the flammability performance of hybrid biocomposites are summarized in Table 8. Furthermore, another attractive approach to reducing the flammability issue is the hybridization of flame-retardants (FRs) and natural fibers in the development process of biocomposites [288-290]. Many studies are currently attempting carbon-based materials as FRs because of their outstanding thermal, chemical, and mechanical properties accompanied by inherent resistance against combustion [291]. In this regard, different types of carbon-based nanofillers such as graphene [292,293], graphite [294-296], fullerene [297,298], graphene nanosheets (GNSs) [299,300], carbon nanotubes (CNTs) [301,302], multi-walled carbon nanotubes (MWCNTs) [294,303], graphene quantum dots (GQDs) [304,305], etc. have been reported to improve the flame retardancy of composites. Biochar is another carbon-rich material as FRs obtained by heating any biomass and renewable sources [306]. Biochar is a renewable alternative for inorganic carbon-based fillers (CNT, fullerene, etc.) [307]. The main function of carbon-based fillers is to form the protective char layer during the pyrolysis of polymeric substances to restrict the transfer of combustible gases and heat and therefore prevent further degradation of materials [291].

Generally, there are various techniques to achieve flame retarding polymeric composites [290]:

- Impregnation of fibers with a solution of the fire retardant

- Addition of microparticles or nanoparticles in matrix or reinforcement phase

- Direct incorporation of fire retardants

- Use of bio-based polymers that can potentially possess inherent fire retardancy

- Incorporation of the fire retardant into the adhesive system

- Mixing of fibers and fire retardant before adding an adhesive

- Chemical modification of matrix

- Surface treatment of fibers

FR materials which cause deceleration of combustion have some functions in composites, such as the reduction of produced heat to the stable level, the formation of a barrier between ambient oxygen $\left(\mathrm{O}_{2}\right)$ and flammable polymers, release of bromine and chlorine atoms by the introduction of materials to polymers, and operation of pyrolysis process to limit the growing of flammable volatiles [308].

To determine the fire behavior of biocomposites, a variety of tests can be performed. For instance, in the limiting oxygen index (LOI) test, the minimum required amount of $\mathrm{O}_{2}$ to support flaming combustion of material can be measured [309]. Cone calorimetry is another attractive technique to evaluate the fire properties of materials. This test can give useful information in different stages regarding the time to ignition (TTI) (ignition stage), heat release rate (HRR) (fire developing stage), and total heat release (THR) (fully developed fire stage) [310]. Vertical burning test (UL-94) and micro-scale combustion calorimetry (MCC) are examples of other techniques to study the flame behavior of materials [291]. Table 8 lists the recent results on the flammability of hybrid biocomposites. 
Table 8. Flammability behavior of recently developed hybrid biocomposites.

\begin{tabular}{|c|c|c|c|c|}
\hline Matrix & Fibers & Manufacturing Process & Flammability & Ref. \\
\hline $\begin{array}{l}\text { Novolac type Phenolic } \\
\text { formaldehyde }\end{array}$ & $\begin{array}{c}\text { PALF/kenaf } \\
\text { Triethoxy (ethyl) silane treatment }\end{array}$ & Hot press & $\begin{array}{l}\text { Phenolic resin formed a protective layer of char on the } \\
\text { surface of composites. } \\
\text { Combustion rates of the untreated hybrid composite were } \\
\text { higher than the treated one. }\end{array}$ & [281] \\
\hline Epoxy & Sisal/coir & Cold pressing & $\begin{array}{l}\text { Increasing the fibers wt \% increased flammability. } \\
\text { This hybrid biocomposite was not suitable where the fire } \\
\text { response is a serious consideration. }\end{array}$ & [275] \\
\hline PLA & Banana fiber and nanoclay fillers ( $3 \mathrm{wt} \%$ ) & $\begin{array}{l}\text { Melt blending technique } \\
\text { followed by injection molding } \\
\text { Silane treatment }\end{array}$ & $\begin{array}{l}\text { Improvement of thermal stability and fire retardancy by } \\
\text { nanoclays that produced char as a thermal barrier to reduce } \\
\text { combustion rate. }\end{array}$ & [311] \\
\hline Cardanol & $\begin{array}{l}\text { Kenaf fibers with recycled carbon filler } \\
\text { Alkali treatment with } 2 \% \mathrm{NaOH}\end{array}$ & Compression molding & $\begin{array}{l}\text { Hybridization of kenaf fibers with recycled carbon filler } \\
\text { improved the thermal stability and flammability property. }\end{array}$ & [312] \\
\hline Epoxy & Banana short fiber and $\mathrm{Al}(\mathrm{OH})_{3}$ filler & Hand lay-up & $\begin{array}{c}\text { Incorporation of } \mathrm{Al}(\mathrm{OH})_{3} \text { particles reduced the rate of } \\
\text { propagation of flame. }\end{array}$ & [313] \\
\hline Polypropylene & Bamboo/glass & Compression molding & $\begin{array}{l}19 \% \text { reduction of heat release rate and increase in the } \\
\text { thermal stability. }\end{array}$ & [314] \\
\hline Polypropylene & Biochar/wool fibers & $\begin{array}{l}\text { Melt blending followed by } \\
\text { injection molding }\end{array}$ & $\begin{array}{c}\text { Improving fire resistance properties: } 5 \mathrm{wt} \% \text { wool fiber } \\
\text { caused a delay in the onset of ignition and the time to reach } \\
\text { peak heat release rate. }\end{array}$ & [287] \\
\hline Polypropylene & $\begin{array}{l}\text { Kenaf fibers with exfoliated graphite } \\
\text { nanoplatelets }\end{array}$ & Melt extrusion & $\begin{array}{l}\text { Graphene nanoplatelets improved the flame retardancy of } \\
\text { composites: the } \\
\text { fire performance index enhanced, the time to ignition } \\
\text { prolonged, and the fire growth index reduced. }\end{array}$ & [315] \\
\hline Epoxy Resin & pineapple/coir (1:1) & Hand lay-up & $\begin{array}{l}\text { Layering pattern of coir/pineapple/coir (CPC) had higher } \\
\text { resistance to burning. }\end{array}$ & [276] \\
\hline $\begin{array}{l}\text { High crystalline block } \\
\text { copolymer polypropylene }\end{array}$ & $\begin{array}{l}\text { Kenaf/wool with ammonium polyphosphate as } \\
\text { a flame retardant and with ultraviolet ray } \\
\text { stabilizer and colorant combination (UVC) }\end{array}$ & $\begin{array}{l}\text { Thermal blending followed by } \\
\text { injection molding }\end{array}$ & $\begin{array}{l}\text { Reduction of sustained and forced combustion of the } \\
\text { composite. } \\
\text { Improvement of material response to the fire hazard. }\end{array}$ & [316] \\
\hline Epoxy & $\begin{array}{c}\text { Bamboo/kenaf/nanoclay } \\
\text { Nanoclay types: halloysite nanotube (HNT), } \\
\text { montmorillonite (MMT), and organically } \\
\text { modified MMT (OMMT) }\end{array}$ & Hand lay-up & $\begin{array}{l}\text { Flame retardancy improved with the loading of all types of } \\
\text { nanoclay (OMMT was the best one). } \\
\text { Improvement in flame properties in terms of peak heat } \\
\text { release rate, total heat release, fire growth rate index, and } \\
\text { the maximum average rate of heat emission and smoke } \\
\text { growth rate. }\end{array}$ & [317] \\
\hline
\end{tabular}


Table 8. Cont

\begin{tabular}{|c|c|c|c|c|}
\hline Matrix & Fibers & Manufacturing Process & Flammability & Ref. \\
\hline Polyester & $\begin{array}{l}\text { Banana peduncle fiber (BPF) with aluminum } \\
\text { hydroxide (AH) particles } \\
\text { Fiber treatment with vinyltriethoxysilane (VTS) } \\
\text { and 3-aminoproply triethoxysilane (APTES) } \\
\text { solutions }\end{array}$ & Hand lay-up & $\begin{array}{l}\text { The addition of } 10 \mathrm{wt} \% \mathrm{AH}: 10 \mathrm{wt} \% \mathrm{BPF} \text { to polyester } \\
\text { composite retarded its burning. } \\
\text { The ignition time and end of burning time delayed by } \\
22.94 \% \text { and } 13.15 \% \text {, respectively. } \\
\text { The total heat release rate decreased by } 29.68 \% \text {. }\end{array}$ & [318] \\
\hline Epoxy & $\begin{array}{l}\text { Kenaf with nano oil palm empty fruit bunch } \\
\text { (OPEFB) filler ( } 3 \mathrm{wt} \%)\end{array}$ & Hand lay-up & $\begin{array}{l}\text { Hybrid nanocomposites presented better (and satisfactory) } \\
\text { flame retardancy properties in comparison to kenaf/epoxy } \\
\text { composites. }\end{array}$ & [319] \\
\hline Epoxy & $\begin{array}{l}\text { Arenga pinnata fiber (APF)/polyester yarn } \\
\text { (PET) }\end{array}$ & $\begin{array}{c}\text { Lay-up } \\
\text { APF:PET ratio }=0: 5,20: 5,35: 5 \\
\text { and } 50: 5 \mathrm{wt} \%\end{array}$ & $\begin{array}{c}\mathrm{Mg}(\mathrm{OH})_{2} \text { as flame retardant. } \\
\text { Hybrid composite of APF35/PET5/E55 with } 5 \mathrm{wt} \% \\
\mathrm{Mg}(\mathrm{OH})_{2} \text { exhibited a lower burning rate. }\end{array}$ & [236] \\
\hline $\begin{array}{l}\text { Ethylene propylene diene } \\
\text { monomer (EPDM) rubber }\end{array}$ & Kevlar fiber (KF)/Nano-silica (NS) & $\begin{array}{l}\text { Roll milling followed by } \\
\text { compression molding }\end{array}$ & $\begin{array}{l}\text { By increasing the KF loading, he flame retardant properties } \\
\text { enhanced. } \\
\text { Hybridization of KF and NS increased the TTI }{ }^{1} \text { noticeably. }\end{array}$ & [237] \\
\hline PLA & $\begin{array}{l}\text { Coir fiber }(\mathrm{CF}) / \mathrm{PALF} \\
\text { Alkaline treatment of fibers }\end{array}$ & $\begin{array}{l}\text { Internal mixer followed by } \\
\text { compression molding } \\
\text { CF:PALF ratios = 3:7, 1:1 and 7:3 }\end{array}$ & $\begin{array}{l}\text { Fibers loading: } 30 \mathrm{wt} \% \\
\text { C1P1 and C7P3 (CF:PALF }=7: 3 \text { ) exhibited higher thermal } \\
\text { stability and char content. }\end{array}$ & [238] \\
\hline
\end{tabular}




\section{Conclusions}

In this report, hybrid biocomposites have been reviewed, especially in mechanical properties, including tensile, flexural, and impact strength, water absorption, and flammability. In this regard, hybrid composites comprising natural-synthetic fibers, natural-natural fibers, and natural fiber hybrid with nanoparticles or fillers were investigated. Using multiple fibers and developing hybrid composites have received popularity due to the enhanced performance of manufactured products and the possibility of overwhelming the drawbacks of purely natural or synthetic fibers reinforced composites. The focus of this concept is to develop multifunctional materials and structures for advanced applications with improved properties. Researchers have applied various strategies in order to improve the mechanical properties of hybrid biocomposites. Adding a second filler in either micro or nano-size, change the weight percentage of natural and synthetic fibers, addition of fire retardants, change in layering stacking sequence, chemical or physical modification, and changing production techniques are some of the critical strategies. Despite significant challenges with compatibility and processing of hybrid materials, the aforementioned applied techniques showed remarkable improvements in strength, water absorption resistance, and flame retardancy.

To sum up, in the investigated studies in this review, hybridizations of natural and synthetic fibers with polymeric matrices as well as employing the optimized amount of substances, such as nanoclays, CNTs, silica, cement, and iron oxide particles, alumina, aluminum hydroxide, and graphite nanoplatelets effectively enhanced mechanical properties (e.g., flexural, tensile, and impact strength, flame, and water absorption resistance). High-performance glass and carbon fibers are still the most applicable synthetic fibers for hybridizing the natural fiber composites in recent years. Moreover, chemical treatments or modifications of fibers generally resulted in better mechanical properties, fire, and water resistance than untreated composites due to the improved fiber-matrix bonding after treatments. Among the processing methods, compression molding and hand lay-up are the most often used techniques for the hybrid composites with polymeric matrix materials.

Undoubtedly, due to the rising environmental, economic, and application concerns, hybrid biocomposites are gaining significant attention in the future and provide a competitive market for numerous industrial applications. Consequently, this concept is still open, and further research on the possible ways to improve hybrid biocomposites' properties has to be done. Modeling and simulation would be desirable facilitators for optimizing these materials properties and addressing the key required changes in production processes.

Author Contributions: Conceptualization and methodology, M.B., J.A., and M.Á.M.; writing—original draft preparation, M.B.; writing—review and editing, M.B., J.A., and M.Á.M.; supervision, J.A., and M.Á.M. All authors have read and agreed to the published version of the manuscript.

Funding: This research received no external funding.

Conflicts of Interest: The authors declare no conflict of interest.

\section{References}

1. Joseph, S.; Jacob, M.; Thomas, S. Natural fiber-rubber composites and their applications. In Natural Fibers, Biopolymers, Biocomposites; Taylor Francis Group, LLC: Bacon Raton, FL, USA, 2005.

2. Mohanty, A.K.; Lawrence, M.M.; Drzal, T. Natural Fibers, Biopolymers, and Biocomposites: An Introduction; CRC Press: Bacon Raton, FL, USA, 2005.

3. European Commission. A Sustainable Bioeconomy for Europe: Strengthening the Connection between Economy, Society and the Environment; Publications Office of the European Union: Brussels, Belgium, 2018.

4. Kargarzadeh, H.; Mariano, M.; Huang, J.; Lin, N.; Ahmad, I.; Dufresne, A.; Thomas, S. Recent developments on nanocellulose reinforced polymer nanocomposites: A review. Polymer 2017, 132, 368-393. [CrossRef]

5. Drzal Lawrence, T.; Mohanty, A.; Misra, M. Bio-composite materials as alternatives to petroleum-based composites for automotive applications. Magnesium 2001, 40, 1-3. 
6. Prameela, K.; Mohan, C.M.; Ramakrishna, C. Biopolymers for Food Design: Consumer-Friendly Natural Ingredients. In Biopolymers for Food Design; Elsevier: Amsterdam, The Netherlands, 2018; pp. 1-32.

7. Ozilgen, S.; Bucak, S. Functional Biopolymers in Food Manufacturing. In Biopolymers for Food Design; Elsevier: Amsterdam, The Netherlands, 2018; pp. 157-189.

8. Sumrith, N.; Rangappa, S.M.; Dangtungee, R.; Siengchin, S.; Jawaid, M.; Pruncu, C.I. Biopolymers-Based Nanocomposites: Properties and Applications. In Bio-Based Polymers and Nanocomposites; Springer: Berlin/Heidelberg, Germany, 2019; pp. 255-272.

9. Sadasivuni, K.K.; Saha, P.; Adhikari, J.; Deshmukh, K.; Ahamed, M.B.; Cabibihan, J.J. Recent advances in mechanical properties of biopolymer composites: A review. Polym. Compos. 2019, 7, 9-17. [CrossRef]

10. Muratore, G.; Nobile, D.; Buonocore, G.; Lanza, C.; Asmundo, N. The influence of using biodegradable packaging films on the quality decay kinetic of plum tomato (PomodorinoDatterino®). Food Eng. 2005, 67, 393-399. [CrossRef]

11. Rhim, J.-W.; Park, H.-M.; Ha, C.-S. Bio-nanocomposites for food packaging applications. Prog. Polym. Sci. 2013, 38, 1629-1652. [CrossRef]

12. Rangari, V.K.; Biswas, M.C.; Tiimob, B.J. Biodegradable Polymer Blends for Food Packaging Applications. In Food Packaging Innovations and Shelf-Life; CRC Press: Boca Raton, FL, USA, 2019; p. 151.

13. Motaung, T.E.; Linganiso, L.Z. Critical review on agrowaste cellulose applications for biopolymers. Int. J. Plast. Technol. 2018, 22, 185-216. [CrossRef]

14. Deshmukh, K.; Ahamed, M.B.; Sadasivuni, K.K.; Ponnamma, D.; AlMaadeed, M.A.A.; Deshmukh, R.R.; Pasha, S.K.; Polu, A.R.; Chidambaram, K. Fumed $\mathrm{SiO}_{2}$ nanoparticle reinforced biopolymer blend nanocomposites with high dielectric constant and low dielectric loss for flexible organic electronics. Appl. Polym. Sci. 2017, 134. [CrossRef]

15. Ashik, K.; Sharma, R.S.; Guptha, V.J. Investigation of moisture absorption and mechanical properties of natural/glass fiber reinforced polymer hybrid composites. Mater. Today Proc. 2018, 5, 3000-3007. [CrossRef]

16. Galvez, P.; Abenojar, J.; Martinez, M.A. Effect of moisture and temperature on the thermal and mechanical properties of a ductile epoxy adhesive for use in steel structures reinforced with CFRP. Compos. Part B Eng. 2019, 176, 107194. [CrossRef]

17. Al-Hajaj, Z.; Zdero, R.; Bougherara, H. Mechanical, morphological, and water absorption properties of a new hybrid composite material made from 4 harness satin woven carbon fibres and flax fibres in an epoxy matrix. Compos. Part A Appl. Sci. Manuf. 2018, 115, 46-56. [CrossRef]

18. Forintos, N.; Czigany, T. Multifunctional application of carbon fiber reinforced polymer composites: Electrical properties of the reinforcing carbon fibers-a short review. Compos. Part B Eng. 2019, 162, 331-343. [CrossRef]

19. Verma, D.; Fortunati, E.; Jain, S.; Zhang, X. Biomass, Biopolymer-Based Materials, and Bioenergy: Construction, Biomedical, and Other Industrial Applications; Woodhead Publishing: Cambridge, UK, 2019.

20. Bindu, J.; Kumar, K.S.; Panda, S.K.; Katiyar, V. Biopolymer Dispersed Poly Lactic Acid Composites and Blends for Food Packaging Applications. In Advances in Sustainable Polymers; Springer: Berlin/Heidelberg, Germany, 2019; pp. 209-235.

21. Daramola, O.O.; Olajide, J.L.; Agwuncha, S.C.; Mochane, M.J.; Sadiku, E.R. Nanostructured Green Biopolymer Composites for Orthopedic Application. In Green Biopolymers and Their Nanocomposites; Springer: Berlin/Heidelberg, Germany, 2019; pp. 159-190.

22. Sangeetha, K.; Vinodhini, P.A.; Sudha, P. Clay Based Biopolymer Nanocomposites and Their Applications in Environmental and Biomedical Fields. In Sustainable Polymer Composites and Nanocomposites; Springer: Berlin/Heidelberg, Germany, 2019; pp. 1159-1183.

23. Ibrahim, I.D.; Sadiku, E.R.; Jamiru, T.; Hamam, Y.; Alayli, Y.; Eze, A.A.; Kupolati, W.K. Biopolymer Composites and Bionanocomposites for Energy Applications. In Green Biopolymers and Their Nanocomposites; Springer: Berlin/Heidelberg, Germany, 2019; pp. 313-341.

24. Allende, M.I.; Davis, B.A.; Miller, J.E.; Christiansen, E.L.; Lepech, M.D.; Loftus, D.J. Hypervelocity Impact Performance of Biopolymer-Bound Soil Composites for Space Construction. Aerosp. Eng. 2020, 33, 04020001. [CrossRef]

25. Angellier, H.; Molina-Boisseau, S.; Dole, P.; Dufresne, A. Thermoplastic starch-Waxy maize starch nanocrystals nanocomposites. Biomacromolecules 2006, 7, 531-539. [CrossRef] [PubMed]

26. Dos Santos Rosa, D.; Lenz, D.M. Biocomposites: Influence of matrix nature and additives on the properties and biodegradation behaviour. Biodegrad. Eng. Technol. Intech Rij. Croat. 2013, 433-475. [CrossRef] 
27. Mochane, M.; Mokhena, T.C.; Mokhothu, T.; Mtibe, A.; Sadiku, E.; Ray, S.S.; Ibrahim, I.; Daramola, O. Recent progress on natural fiber hybrid composites for advanced applications: A review. Gen. Sci. Eng. Technol. 2019. [CrossRef]

28. Islam, M.S.; Ramli, I.B.; Hasan, M.; Islam, M.M.; Islam, K.N.; Hasan, M.; Harmaen, A.S. Effect of kenaf and EFB fiber hybridization on physical and thermo-mechanical properties of PLA biocomposites. Fibers Polym. 2017, 18, 116-121. [CrossRef]

29. Potluri, R. Natural Fiber-Based Hybrid Bio-composites: Processing, Characterization, and Applications. In Green Composites; Springer: Berlin/Heidelberg, Germany, 2019; pp. 1-46.

30. Siakeng, R.; Jawaid, M.; Ariffin, H.; Sapuan, S. Thermal properties of coir and pineapple leaf fibre reinforced polylactic acid hybrid composites. In IOP Conference Series: Materials Science and Engineering, Proceedings of the International Conference on Advances in Manufacturing and Materials Engineering (ICAMME 2017), Kuala Lumpur, Malaysia, 8-9 August 2017; IOP Publishing: Bristol, UK, 2018; p. 012019.

31. Asim, M.; Jawaid, M.; Paridah, M.T.; Saba, N.; Nasir, M.; Shahroze, R.M. Dynamic and thermo-mechanical properties of hybridized kenaf/PALF reinforced phenolic composites. Polym. Compos. 2019, 40, 3814-3822. [CrossRef]

32. Sreekala, M.; George, J.; Kumaran, M.; Thomas, S. The mechanical performance of hybrid phenol-formaldehyde-based composites reinforced with glass and oil palm fibres. Compos. Sci. Technol. 2002, 62, 339-353. [CrossRef]

33. Zweben, C. Tensile strength of hybrid composites. Mater. Sci. 1977, 12, 1325-1337. [CrossRef]

34. Hariharan, A.B.A.; Khalil, H.A. Lignocellulose-based hybrid bilayer laminate composite: Part I-Studies on tensile and impact behavior of oil palm fiber-glass fiber-reinforced epoxy resin. Compos. Mater. 2005, 39, 663-684. [CrossRef]

35. Marom, G.; Fischer, S.; Tuler, F.; Wagner, H. Hybrid effects in composites: Conditions for positive or negative effects versus rule-of-mixtures behaviour. Mater. Sci. 1978, 13, 1419-1426. [CrossRef]

36. Dong, C. Review of natural fibre-reinforced hybrid composites. Reinf. Plast. Compos. 2018, 37, 331-348.

37. Bassyouni, M.; Javaid, U.; ul Hasan, S.W. Bio-based hybrid polymer composites: A sustainable high performance material. In Hybrid Polymer Composite Materials; Elsevier: Amsterdam, The Netherlands, 2017; pp. 23-70.

38. Gurunathan, T.; Mohanty, S.; Nayak, S.K. A review of the recent developments in biocomposites based on natural fibres and their application perspectives. Compos. Part A Appl. Sci. Manuf. 2015, 77, 1-25.

39. Bledzki, A.; Gassan, J. Progress in Polym. Science 1999, 24, 221.

40. Dhyani, V.; Bhaskar, T. Pyrolysis of Biomass. In Biofuels: Alternative Feedstocks and Conversion Processes for the Production of Liquid and Gaseous Biofuels; Elsevier: Amsterdam, The Netherlands, 2019; pp. 217-244.

41. Nevell, T.P.; Zeronian, S.H. (Eds.) Cellulose Chemistry and Its Applications; Ellis Horwood Ltd: Hemel Hempstead, UK, 1985.

42. Kim, C.-H.; Cho, K.; Park, J.-K. Grafting of glycidyl methacrylate onto polycaprolactone: Preparation and characterization. Polymer 2001, 42, 5135-5142. [CrossRef]

43. Azwa, Z.; Yousif, B.; Manalo, A.; Karunasena, W. A review on the degradability of polymeric composites based on natural fibres. Mater. Des. 2013, 47, 424-442. [CrossRef]

44. Mokhothu, T.H.; John, M.J. Review on hygroscopic aging of cellulose fibres and their biocomposites. Carbohydr. Polym. 2015, 131, 337-354. [CrossRef]

45. John, M.J.; Thomas, S. Biofibres and biocomposites. Carbohydr. Polym. 2008, 71, 343-364. [CrossRef]

46. Singh, S.; Mohanty, A. Wood fiber reinforced bacterial bioplastic composites: Fabrication and performance evaluation. Compos. Sci. Technol. 2007, 67, 1753-1763. [CrossRef]

47. Cousins, W. Young's modulus of hemicellulose as related to moisture content. Wood Sci. Technol. 1978, 12, 161-167. [CrossRef]

48. Jarvis, M.C. Structure and properties of pectin gels in plant cell walls. Plant. Cell Environ. 1984, 7, $153-164$.

49. Satyanarayana, K.G.; Arizaga, G.G.; Wypych, F. Biodegradable composites based on lignocellulosic fibers-An overview. Prog. Polym. Sci. 2009, 34, 982-1021. [CrossRef]

50. Ramamoorthy, S.K.; Skrifvars, M.; Persson, A. A review of natural fibers used in biocomposites: Plant, animal and regenerated cellulose fibers. Polym. Rev. 2015, 55, 107-162. [CrossRef] 
51. Marques, A.R.; de Oliveira Patrício, P.S.; dos Santos, F.S.; Monteiro, M.L.; de Carvalho Urashima, D.; de Souza Rodrigues, $C$. Effects of the climatic conditions of the southeastern Brazil on degradation the fibers of coir-geotextile: Evaluation of mechanical and structural properties. Geotext. Geomembr. 2014, 42, 76-82. [CrossRef]

52. Bledzki, A.; Gassan, J. Composites reinforced with cellulose based fibres. Prog. Polym. Sci. 1999, 24, $221-274$. [CrossRef]

53. Fuqua, M.A.; Huo, S.; Ulven, C.A. Natural fiber reinforced composites. Polym. Rev. 2012, 52, $259-320$. [CrossRef]

54. Mwaikambo, L.a.; Ansell, M. Mechanical properties of alkali treated plant fibres and their potential as reinforcement materials. I. Hemp fibres. Mater. Sci. 2006, 41, 2483-2496. [CrossRef]

55. Dicker, M.P.; Duckworth, P.F.; Baker, A.B.; Francois, G.; Hazzard, M.K.; Weaver, P.M. Green composites: A review of material attributes and complementary applications. Compos. Part A Appl. Sci. Manuf. 2014, 56, 280-289. [CrossRef]

56. Faruk, O.; Bledzki, A.K.; Fink, H.-P.; Sain, M. Biocomposites reinforced with natural fibers: 2000-2010. Prog. Polym. Sci. 2012, 37, 1552-1596. [CrossRef]

57. Li, X.; Tabil, L.G.; Panigrahi, S. Chemical treatments of natural fiber for use in natural fiber-reinforced composites: A review. Polym. Environ. 2007, 15, 25-33. [CrossRef]

58. Mwaikambo, L. Review of the history, properties and application of plant fibres. Afr. J. Sci. Technol. 2006, $7,121$.

59. Mohanty, A.; Misra, M.A.; Hinrichsen, G. Biofibres, biodegradable polymers and biocomposites: An overview. Macromol. Mater. Eng. 2000, 276, 1-24. [CrossRef]

60. John, M.J.; Anandjiwala, R.D. Recent developments in chemical modification and characterization of natural fiber-reinforced composites. Polym. Compos. 2008, 29, 187-207. [CrossRef]

61. Sathishkumar, T.; Navaneethakrishnan, P.; Shankar, S.; Rajasekar, R.; Rajini, N. Characterization of natural fiber and composites-A review. J. Reinf. Plast. Compos. 2013, 32, 1457-1476. [CrossRef]

62. Jawaid, M.; Khalil, H.A. Cellulosic/synthetic fibre reinforced polymer hybrid composites: A review. Carbohydr. Polym. 2011, 86, 1-18. [CrossRef]

63. Komuraiah, A.; Kumar, N.S.; Prasad, B.D. Chemical composition of natural fibers and its influence on their mechanical properties. Mech. Compos. Mater. 2014, 50, 359-376. [CrossRef]

64. Murkherjee, P.; Satyanarayana, K. Structure and properties of some vegetable fibers-Part 1: Sisal fiber. Mater. Sci. 1984, 19, 3925-3934. [CrossRef]

65. Murherjee, P.; Satyanarayana, K. Structure and properties of some vegetable fibers-Part 2 Pineapple fiber (Ananas comosus). Mater. Sci. 1986, 21, 51-56. [CrossRef]

66. Varma, D.; Varma, M.; Varma, I. Coir fibers: Part I: Effect of physical and chemical treatments on properties. Text. Res. J. 1984, 54, 827-832. [CrossRef]

67. Li, Y.; Mai, Y.-W.; Ye, L. Sisal fibre and its composites: A review of recent developments. Compos. Sci. Technol. 2000, 60, 2037-2055. [CrossRef]

68. Duhovic, M.; Peterson, S.; Jayaraman, K. Natural-fibre-biodegradable polymer composites for packaging. In Properties and Performance of Natural-Fibre Composites; Elsevier: Amsterdam, The Netherlands, 2008; pp. 301-329.

69. Sanjay, M.; Siengchin, S.; Parameswaranpillai, J.; Jawaid, M.; Pruncu, C.I.; Khan, A. A comprehensive review of techniques for natural fibers as reinforcement in composites: Preparation, processing and characterization. Carbohydr. Polym. 2019, 207, 108-121.

70. Sanjay, M.; Arpitha, G.; Naik, L.L.; Gopalakrishna, K.; Yogesha, B. Applications of natural fibers and its composites: An overview. Nat. Resour. 2016, 7, 108-114. [CrossRef]

71. Wenger, J.; Stern, T.; Schoggl, J.; Ree, R.; Corato, U.; Bari, I.; Bell, G.; Stichnothe, H. Natural Fibers and Fiber-Based Materials in Biorefineries: Status Report 2018; IEA Bioenergy: Paris, France, 2018; ISBN 978-1-910154-53-3.

72. Carlsson, L.A.; Adams, D.F.; Pipes, R.B. Experimental Characterization of Advanced Composite Materials; CRC Press: Boca Raton, FL, USA, 2014.

73. Rahman, R.; Putra, S.Z.F.S. Tensile properties of natural and synthetic fiber-reinforced polymer composites. In Mechanical and Physical Testing of Biocomposites, Fibre-Reinforced Composites and Hybrid Composites; Elsevier: Amsterdam, The Netherlands, 2019; pp. 81-102. 
74. Yan, L.; Kasal, B.; Huang, L. A review of recent research on the use of cellulosic fibres, their fibre fabric reinforced cementitious, geo-polymer and polymer composites in civil engineering. Compos. Part B Eng. 2016, 92, 94-132. [CrossRef]

75. Zhang, Y.; Li, Y.; Ma, H.; Yu, T. Tensile and interfacial properties of unidirectional flax/glass fiber reinforced hybrid composites. Compos. Sci. Technol. 2013, 88, 172-177. [CrossRef]

76. Murawski, A.; Diaz, R.; Inglesby, S.; Delabar, K.; Quirino, R.L. Synthesis of Bio-based Polymer Composites: Fabrication, Fillers, Properties, and Challenges. In Polymer Nanocomposites in Biomedical Engineering; Springer: Berlin/Heidelberg, Germany, 2019; pp. 29-55.

77. Zaid, A.; Jimeniez, E. Date palm cultivation. In FAO Plant Production and Protection Paper; Food and Agriculture Organization (FAO): Rome, Italy, 1999; p. 287.

78. Ma, S.; Li, T.; Liu, X.; Zhu, J. Research progress on bio-based thermosetting resins. Polym. Int. 2016, 65, 164-173. [CrossRef]

79. Rodriguez-Castellanos, W.; Rodrigue, D. Production and Characterization of Hybrid Polymer Composites Based on Natural Fibers. In Composites from Renewable and Sustainable Materials; InTech: London, UK, 2016; pp. 273-302.

80. Niaounakis, M. Biopolymers: Applications and Trends; William Andrew: Norwich, NY, USA, 2015.

81. Zhu, J. Development of Novel Flax Bio-Matrix Composites for Non-Structural and Structural Vehicle Applications. Ph.D. Thesis, Cranfield University, Bedford, UK, 2015.

82. Bravo, A.; Toubal, L.; Koffi, D.; Erchiqui, F. Development of novel green and biocomposite materials: Tensile and flexural properties and damage analysis using acoustic emission. Mater. Des. 1980-2015 2015, 66, 16-28. [CrossRef]

83. Stevens, C.V. Bio-Based Plastics: Materials and Applications; John Wiley \& Sons: Hoboken, NJ, USA, 2013.

84. Ganster, J.; Fink, H.-P. Man-Made Cellulose Short Fiber Reinforced Oil and Bio-Based Thermoplastics. In Cellulose Fibers: Bio-and Nano-Polymer Composites; Springer: Berlin/Heidelberg, Germany, 2011; pp. 479-506.

85. Zhang, Y.; Yuan, Z.; Xu, C.C. Bio-based resins for fiber-reinforced polymer composites. In Natural Fiber-Reinforced Biodegradable and Bioresorbable Polymer Composites; Elsevier: Amsterdam, The Netherlands, 2017; pp. 137-162.

86. Graupner, N.; Herrmann, A.S.; Müssig, J. Natural and man-made cellulose fibre-reinforced poly (lactic acid)(PLA) composites: An overview about mechanical characteristics and application areas. Compos. Part $A$ Appl. Sci. Manuf. 2009, 40, 810-821. [CrossRef]

87. Farah, S.; Anderson, D.G.; Langer, R. Physical and mechanical properties of PLA, and their functions in widespread applications-A comprehensive review. Adv. Drug Deliv. Rev. 2016, 107, 367-392. [CrossRef]

88. Kamthai, S.; Magaraphan, R. Thermal and mechanical properties of polylactic acid (PLA) and bagasse carboxymethyl cellulose (CMCB) composite by adding isosorbide diesters. AIP Conf. Proc. 2015, 1664, 060006. [CrossRef]

89. Williams, J.K.; Yoo, J.J.; Atala, A. Regenerative medicine approaches for tissue engineered heart valves. In Principles of Regenerative Medicine; Elsevier: Amsterdam, The Netherlands, 2019; pp. 1041-1058.

90. Díez-Pascual, A.M. Biodegradable food packaging nanocomposites based on ZnO-reinforced polyhydroxyalkanoates. In Food Packaging; Elsevier: Amsterdam, The Netherlands, 2017; pp. 185-221.

91. Russell, R.A.; Garvey, C.J.; Darwish, T.A.; Foster, L.J.R.; Holden, P.J. Biopolymer deuteration for neutron scattering and other isotope-sensitive techniques. In Methods in Enzymology; Elsevier: Amsterdam, The Netherlands, 2015; Volume 565, pp. 97-121.

92. Zhang, Z.; Ortiz, O.; Goyal, R.; Kohn, J. Biodegradable polymers. In Handbook of Polymer Applications in Medicine and Medical Devices; Elsevier: Amsterdam, The Netherlands, 2014; pp. 303-335.

93. Madison, L.L.; Huisman, G.W. Metabolic engineering of poly (3-hydroxyalkanoates): From DNA to plastic. Microbiol. Mol. Biol. Rev. 1999, 63, 21-53. [CrossRef] [PubMed]

94. Griffin, G.J. Chemistry and Technology of Biodegradable Polymers; Blackie Academic and Professional: London, UK, 1994.

95. Reddy, C.; Ghai, R.; Kalia, V.C. Polyhydroxyalkanoates: An overview. Bioresour. Technol. 2003, 87, 137-146. [CrossRef]

96. Roy, I.; Visakh, P. Polyhydroxyalkanoate (PHA) Based Blends, Composites and Nanocomposites; Royal Society of Chemistry: Cambridge, UK, 2014; Volume 30. 
97. Ten, E.; Jiang, L.; Zhang, J.; Wolcott, M.P. Mechanical performance of polyhydroxyalkanoate (PHA)-based biocomposites. In Biocomposites; Elsevier: Amsterdam, The Netherlands, 2015; pp. 39-52.

98. Niaounakis, M. Biopolymers: Processing and Products; William Andrew: Norwich, NY, USA, 2014.

99. Jamaluddin, N.; Razaina, M.; Ishak, Z.M. Mechanical and morphology behaviours of polybutylene (succinate)/thermoplastic polyurethaneblend. Procedia Chem. 2016, 19, 426-432. [CrossRef]

100. Chen, G.X.; Kim, E.S.; Yoon, J.S. Poly (butylene succinate)/twice functionalized organoclay nanocomposites: Preparation, characterization, and properties. Appl. Polym. Sci. 2005, 98, 1727-1732. [CrossRef]

101. Someya, Y.; Nakazato, T.; Teramoto, N.; Shibata, M. Thermal and mechanical properties of poly (butylene succinate) nanocomposites with various organo-modified montmorillonites. Appl. Polym. Sci. 2004, 91, 1463-1475. [CrossRef]

102. Han, H.; Wang, X.; Wu, D. Mechanical properties, morphology and crystallization kinetic studies of bio-based thermoplastic composites of poly (butylene succinate) with recycled carbon fiber. Chem. Technol. Biotechnol. 2013, 88, 1200-1211. [CrossRef]

103. Song, L.; Qiu, Z. Influence of low multi-walled carbon nanotubes loadings on the crystallization behavior of biodegradable poly (butylene succinate) nanocomposites. Polym. Adv. Technol. 2011, 22, 1642-1649. [CrossRef]

104. Yuan, L.; Wu, D.; Zhang, M.; Zhou, W.; Lin, D. Rheological percolation behavior and isothermal crystallization of poly (butyene succinte)/carbon nanotube composites. Ind. Eng. Chem. Res. 2011, 50, 14186-14192. [CrossRef]

105. Ge, F.; Wang, X.; Ran, X. Properties of biodegradable poly (butylene succinate)(PBS) composites with carbon black. Polym. Sci. Ser. A 2017, 59, 416-424. [CrossRef]

106. McKeen, L.W. The Effect of UV Light and Weather on Plastics and Elastomers; William Andrew: Norwich, NY, USA, 2019.

107. Kausar, A. Physical properties of hybrid polymer/clay composites. In Hybrid Polymer Composite Materials; Elsevier: Amsterdam, The Netherlands, 2017; pp. 115-132.

108. Di Lorenzo, M.L.; Longo, A.; Androsch, R. Polyamide 11/Poly (butylene succinate) Bio-Based Polymer Blends. Materials 2019, 12, 2833. [CrossRef]

109. Patel, R.; Ruehle, D.A.; Dorgan, J.R.; Halley, P.; Martin, D. Biorenewable blends of polyamide-11 and polylactide. Polym. Eng. Sci. 2014, 54, 1523-1532. [CrossRef]

110. Liu, T.; Lim, K.P.; Tjiu, W.C.; Pramoda, K.; Chen, Z.-K. Preparation and characterization of nylon 11/organoclay nanocomposites. Polymer 2003, 44, 3529-3535. [CrossRef]

111. Jariyavidyanont, K.; Focke, W.; Androsch, R. Thermal properties of biobased polyamide 11. Therm. Prop. Bio-Based Polym. 2019, 143-187. [CrossRef]

112. Stoclet, G.; Seguela, R.; Lefebvre, J.-M. Morphology, thermal behavior and mechanical properties of binary blends of compatible biosourced polymers: Polylactide/polyamide11. Polymer 2011, 52, 1417-1425. [CrossRef]

113. Heshmati, V.; Zolali, A.M.; Favis, B.D. Morphology development in poly (lactic acid)/polyamide11 biobased blends: Chain mobility and interfacial interactions. Polymer 2017, 120, 197-208. [CrossRef]

114. Ke, Y.; Zhang, X.; Ramakrishna, S.; He, L.; Wu, G. Reactive blends based on polyhydroxyalkanoates: Preparation and biomedical application. Mater. Sci. Eng. C 2017, 70, 1107-1119. [CrossRef]

115. Tercjak, A.; Haponiuk, J.; Masiulanis, B. Study of thermal property changes of biopol/polyamide 11 blends during biodegradation in compost. J. Therm. Anal. Calorim. 2003, 74, 605-608. [CrossRef]

116. Moriyama, T.; Sumiya, N.; Saito, T. Impact strength improvement of polyamide 11 without flexural modulus reduction by dispersing poly (butylene succinate) particles. Polym. J. 2016, 48, 221-224. [CrossRef]

117. Jariyavidyanont, K.; Focke, W.; Androsch, R. Crystallization kinetics of polyamide 11 in the presence of sepiolite and montmorillonite nanofillers. Colloid Polym. Sci. 2016, 294, 1143-1151. [CrossRef]

118. Halim, K.A.A.; Farrell, J.B.; Kennedy, J.E. Preparation and characterisation of polyamide 11/montmorillonite (MMT) nanocomposites for use in angioplasty balloon applications. Mater. Chem. Phys. 2013, 143, 336-348. [CrossRef]

119. Sahnoune, M.; Taguet, A.; Otazaghine, B.; Kaci, M.; Lopez-Cuesta, J.-M. Effects of functionalized halloysite on morphology and properties of polyamide-11/SEBS-g-MA blends. Eur. Polym. J. 2017, 90, 418-430. [CrossRef]

120. Mahapatro, A.; Singh, D.K. Biodegradable nanoparticles are excellent vehicle for site directed in-vivo delivery of drugs and vaccines. J. Nanobiotechnol. 2011, 9, 55. [CrossRef] [PubMed] 
121. Kabilan, S.; Ayyasamy, M.; Jayavel, S.; Paramasamy, G. Pseudomonas sp. as a source of medium chain length polyhydroxyalkanoates for controlled drug delivery: Perspective. Int. J. Microbiol. 2012, 2012. [CrossRef] [PubMed]

122. Xu, J.; Manepalli, P.H.; Zhu, L.; Narayan-Sarathy, S.; Alavi, S. Morphological, barrier and mechanical properties of films from poly (butylene succinate) reinforced with nanocrystalline cellulose and chitin whiskers using melt extrusion. J. Polym. Res. 2019, 26, 188. [CrossRef]

123. Jiang, Y.; Loos, K. Enzymatic synthesis of biobased polyesters and polyamides. Polymers 2016, 8, 243. [CrossRef]

124. Laine, L.; Rozite, L. Eco-Efficient Composite Materials; European Union European Regional Development Fund. October 2010. Available online: https://people.arcada.fi/ \{\}rene/biocomposites/lectures/STATE\% 20OF\%20THE\%20ART_material_examples.pdf (accessed on 12 November 2020).

125. Pilla, S. Handbook of Bioplastics and Biocomposites Engineering Applications; John Wiley \& Sons: Hoboken, NJ, USA, 2011; Volume 81.

126. Lutton, R.; Taylor, S.; Sonebi, M.; Murphy, A. Commercial potential of bioresins and their success in thermosetting composites: An overview. In Proceedings of the ICBBM ECOGRAFI, Clermont-Ferrand, France, 21-23 June 2017.

127. Jin, F.-L.; Li, X.; Park, S.-J. Synthesis and application of epoxy resins: A review. Ind. Eng. Chem. 2015, 29, 1-11. [CrossRef]

128. Kausar, A. Role of thermosetting polymer in structural composite. Am. J. Polym. Sci. Eng. 2017, 5, 1-12.

129. Hamerton, I.; Mooring, L. The use of thermosets in aerospace applications. In Thermosets; Elsevier: Amsterdam, The Netherlands, 2012; pp. 189-227.

130. Yang, Y.; Boom, R.; Irion, B.; van Heerden, D.-J.; Kuiper, P.; de Wit, H. Recycling of composite materials. Chem. Eng. Process. Process. Intensif. 2012, 51, 53-68. [CrossRef]

131. Ma, S.; Liu, X.; Jiang, Y.; Tang, Z.; Zhang, C.; Zhu, J. Bio-based epoxy resin from itaconic acid and its thermosets cured with anhydride and comonomers. Green Chem. 2013, 15, 245-254. [CrossRef]

132. Zabihi, O.; Ahmadi, M.; Khayyam, H.; Naebe, M. Fish DNA-modified clays: Towards highly flame retardant polymer nanocomposite with improved interfacial and mechanical performance. Sci. Rep. 2016, 6, 1-17. [CrossRef]

133. Ramon, E.; Sguazzo, C.; Moreira, P.M. A review of recent research on bio-based epoxy systems for engineering applications and potentialities in the aviation sector. Aerospace 2018, 5, 110. [CrossRef]

134. Raquez, J.-M.; Deléglise, M.; Lacrampe, M.-F.; Krawczak, P. Thermosetting (bio) materials derived from renewable resources: A critical review. Prog. Polym. Sci. 2010, 35, 487-509. [CrossRef]

135. Cardona, F.; Aravinthan, T.; Fedrigo, J.; Moscou, C. Synthesis of phenolic bio-resins for advanced composites in civil engineering structures. In Proceedings of the Southern Region Engineering Conference (SREC 2010), Toowoomba, Australia, 11-12 November 2010; pp. 58-64.

136. Ono, H.; Sudo, K.; Karasawa, H. Phenolated wood-a source of wood adhesives. In Proceedings of the International Symposium on Chemical Modification of Wood, Kyoto, Japan, 17-18 May 1991; pp. 35-37.

137. Maldas, D.; Shiraishi, N. Liquefaction of biomass in the presence of phenol and $\mathrm{H}_{2} \mathrm{O}$ using alkalies and salts as the catalyst. Biomass Bioenergy 1997, 12, 273-279. [CrossRef]

138. US National Renewable Energy Laboratory (NREL). Available online: http://www.nrel.gov/docs/legosti/old/ 5819.pdf (accessed on 23 September 2020).

139. Gani, A.; Naruse, I. Effect of cellulose and lignin content on pyrolysis and combustion characteristics for several types of biomass. Renew. Energy 2007, 32, 649-661. [CrossRef]

140. Bridgwater, A.; Peacocke, G. Fast pyrolysis processes for biomass. Renew. Sustain. Energy Rev. 2000, 4, 1-73. [CrossRef]

141. Maxineasa, S.G.; Taranu, N. Life cycle analysis of strengthening concrete beams with FRP. In Eco-Efficient Repair and Rehabilitation of Concrete Infrastructures; Elsevier: Amsterdam, The Netherlands, 2018; pp. 673-721.

142. Loos, M. Carbon Nanotube Reinforced Composites: CNT Polymer Science and Technology; Elsevier: Amsterdam, The Netherlands, 2014.

143. Jawaid, M.; Thariq, M.; Saba, N. Mechanical and Physical Testing of Biocomposites, Fibre-Reinforced Composites and Hybrid Composites; Woodhead Publishing: Cambridge, UK, 2018.

144. Sheel, A.; Pant, D. Chemical Depolymerization of PET Bottles via Glycolysis. In Recycling of Polyethylene Terephthalate Bottles; Elsevier: Amsterdam, The Netherlands, 2019; pp. 61-84. 
145. Transparency Market Research. Itaconic Acid Market for Synthetic Latex, Unsaturated Polyester Resins, Detergents, Superabsorbent Polymers (SAP), and Other Applications-Global Industry Analysis, Size, Share, Growth, Trends and Forecast 2015-2023, TMRGL5492; Transparency Market Research: Albany, NY, USA, 27 July 2015.

146. Mighani, H. Synthesis of thermally stable polyesters. In Polyester; InTech: Rijeka, Croatia, 2012; pp. 3-17.

147. Fink, J.K. Reactive Polymers: Fundamentals and Applications: A Concise Guide to Industrial Polymers; William Andrew: Norwich, NY, USA, 2017.

148. Meier, M.A.; Metzger, J.O.; Schubert, U.S. Plant oil renewable resources as green alternatives in polymer science. Chem. Soc. Rev. 2007, 36, 1788-1802. [CrossRef]

149. Biermann, U.; Bornscheuer, U.; Meier, M.A.; Metzger, J.O.; Schäfer, H.J. Oils and fats as renewable raw materials in chemistry. Angew. Chem. Int. Ed. 2011, 50, 3854-3871. [CrossRef]

150. Mehta, G.; Mohanty, A.; Misra, M.; Drzal, L. Biobased resin as a toughening agent for biocomposites. Green Chem. 2004, 6, 254-258. [CrossRef]

151. Das, K.; Ray, D.; Banerjee, C.; Bandyopadhyay, N.; Mohanty, A.K.; Misra, M. Novel materials from unsaturated polyester resin/styrene/tung oil blends with high impact strengths and enhanced mechanical properties. Appl. Polym. Sci. 2011, 119, 2174-2182. [CrossRef]

152. Kureemun, U.; Ravandi, M.; Tran, L.; Teo, W.; Tay, T.; Lee, H. Effects of hybridization and hybrid fibre dispersion on the mechanical properties of woven flax-carbon epoxy at low carbon fibre volume fractions. Compos. Part B Eng. 2018, 134, 28-38. [CrossRef]

153. Nguyen, H.; Zatar, W.; Mutsuyoshi, H. Mechanical properties of hybrid polymer composite. In Hybrid Polymer Composite Materials; Elsevier: Amsterdam, The Netherlands, 2017; pp. 83-113.

154. Ismail, K.I.; Sultan, M.T.H.H.; Shah, A.U.; Mazlan, N.; Ariffin, A.H. Tensile Properties of Hybrid Biocomposite Reinforced Epoxy Modified with Carbon Nanotube (CNT). BioResources 2018, 13, 1787-1800. [CrossRef]

155. Sathishkumar, T.; Ramakrishnan, S.; Navaneethakrishnan, P. Effect of Glass and Banana Fiber Mat Orientation and Number of Layers on Mechanical Properties of Hybrid Composites. In Biofibers and Biopolymers for Biocomposites; Springer: Berlin/Heidelberg, Germany, 2020; pp. 295-312.

156. Prasanna, G.; Venkatesha. Surface modification, characterization and optimization of hybrid bio composites. In Fatigue, Durability, and Fracture Mechanics; Springer: Singapore, 2020; p. 632. [CrossRef]

157. Ku, H.; Wang, H.; Pattarachaiyakoop, N.; Trada, M. A review on the tensile properties of natural fiber reinforced polymer composites. Compos. Part B Eng. 2011, 42, 856-873. [CrossRef]

158. Malkapuram, R.; Kumar, V.; Negi, Y.S. Recent development in natural fiber reinforced polypropylene composites. J. Reinf. Plast. Compos. 2009, 28, 1169-1189. [CrossRef]

159. Holbery, J.; Houston, D. Natural-fiber-reinforced polymer composites in automotive applications. JOM 2006, 58, 80-86. [CrossRef]

160. Lee, B.-H.; Kim, H.-J.; Yu, W.-R. Fabrication of long and discontinuous natural fiber reinforced polypropylene biocomposites and their mechanical properties. Fibers Polym. 2009, 10, 83-90. [CrossRef]

161. López Manchado, M.; Arroyo, M.; Biagiotti, J.; Kenny, J. Enhancement of mechanical properties and interfacial adhesion of PP/EPDM/flax fiber composites using maleic anhydride as a compatibilizer. J. Appl. Polym. Sci. 2003, 90, 2170-2178. [CrossRef]

162. Liu, L.; Yu, J.; Cheng, L.; Qu, W. Mechanical properties of poly (butylene succinate)(PBS) biocomposites reinforced with surface modified jute fibre. Compos. Part A Appl. Sci. Manuf. 2009, 40, 669-674. [CrossRef]

163. Phillips, L. The hybrid effect-does it exist? Composites 1976, 7, 7-8. [CrossRef]

164. Hayashi, T. On the improvement of mechanical properties of composites by hybrid composition. In Proceedings of the 8th Reinforced Plastics Conference, London, UK, 10-12 October 1972; pp. 149-152.

165. Bunsell, A.; Harris, B. Hybrid carbon and glass fibre composites. Composites 1974, 5, 157-164. [CrossRef]

166. Swolfs, Y.; Gorbatikh, L.; Verpoest, I. Fibre hybridisation in polymer composites: A review. Compos. Part A Appl. Sci. Manuf. 2014, 67, 181-200. [CrossRef]

167. Enfedaque, A.; Molina-Aldareguía, J.; Gálvez, F.; González, C.; Llorca, J. Effect of glass fiber hybridization on the behavior under impact of woven carbon fiber/epoxy laminates. J. Compos. Mater. 2010, 44, 3051-3068. [CrossRef]

168. Sevkat, E.; Liaw, B.; Delale, F.; Raju, B.B. Drop-weight impact of plain-woven hybrid glass-graphite/toughened epoxy composites. Compos. Part A Appl. Sci. Manuf. 2009, 40, 1090-1110. [CrossRef]

169. Onal, L.; Adanur, S. Effect of stacking sequence on the mechanical properties of glass-carbon hybrid composites before and after impact. J. Ind. Text. 2002, 31, 255-271. [CrossRef] 
170. Naik, N.; Ramasimha, R.; Arya, H.; Prabhu, S.; ShamaRao, N. Impact response and damage tolerance characteristics of glass-carbon/epoxy hybrid composite plates. Compos. Part B Eng. 2001, 32, 565-574. [CrossRef]

171. Sevkat, E.; Liaw, B.; Delale, F.; Raju, B.B. Effect of repeated impacts on the response of plain-woven hybrid composites. Compos. Part B Eng. 2010, 41, 403-413. [CrossRef]

172. P., D.C. Interlayer Hybridisation of Steel Fibre and Self-Reinforced Composites; KU Leuven: Leuven, Belgium, 2012.

173. Park, R.; Jang, J. Effect of laminate geometry on impact performance of aramid fiber/polyethylene fiber hybrid composites. Appl. Polym. Sci. 2000, 75, 952-959. [CrossRef]

174. Peijs, A.; Venderbosch, R. Hybrid composites based on polyethylene and carbon fibres Part IV Influence of hybrid design on impact strength. Mater. Sci. Lett. 1991, 10, 1122-1124. [CrossRef]

175. Saito, H.; Morita, M.; Kawabe, K.; Kanesaki, M.; Takeuchi, H.; Tanaka, M.; Kimpara, I. Effect of ply-thickness on impact damage morphology in CFRP laminates. J. Reinf. Plast. Compos. 2011, 30, 1097-1106. [CrossRef]

176. Galvez, P.; Quesada, A.; Martinez, M.A.; Abenojar, J.; Boada, M.J.L.; Diaz, V. Study of the behaviour of adhesive joints of steel with CFRP for its application in bus structures. Compos. Part B Eng. 2017, 129, 41-46. [CrossRef]

177. Thiagamani, S.M.K.; Krishnasamy, S.; Muthukumar, C.; Tengsuthiwat, J.; Nagarajan, R.; Siengchin, S.; Ismail, S.O. Investigation into mechanical, absorption and swelling behaviour of hemp/sisal fibre reinforced bioepoxy hybrid composites: Effects of stacking sequences. Int. J. Biol. Macromol. 2019, 140, 637-646. [CrossRef]

178. Yahaya, R.; Sapuan, S.; Jawaid, M.; Leman, Z.; Zainudin, E. Effect of layering sequence and chemical treatment on the mechanical properties of woven kenaf-aramid hybrid laminated composites. Mater. Des. 2015, 67, 173-179. [CrossRef]

179. Guna, V.; Ilangovan, M.; Ananthaprasad, M.; Reddy, N. Hybrid biocomposites. Polym. Compos. 2018, 39, E30-E54. [CrossRef]

180. Manteghi, S.; Mahboob, Z.; Fawaz, Z.; Bougherara, H. Investigation of the mechanical properties and failure modes of hybrid natural fiber composites for potential bone fracture fixation plates. J. Mech. Behav. Biomed. Mater. 2017, 65, 306-316. [CrossRef] [PubMed]

181. Yusoff, R.B.; Takagi, H.; Nakagaito, A.N. Tensile and flexural properties of polylactic acid-based hybrid green composites reinforced by kenaf, bamboo and coir fibers. Ind. Crop. Prod. 2016, 94, 562-573. [CrossRef]

182. Subagia, I.A.; Kim, Y.; Tijing, L.D.; Kim, C.S.; Shon, H.K. Effect of stacking sequence on the flexural properties of hybrid composites reinforced with carbon and basalt fibers. Compos. Part B Eng. 2014, 58, 251-258. [CrossRef]

183. Sivasaravanan, S.; Bupesh Raja, V.K. Impact characterization of epoxy LY556/E-glass fibre/nano clay hybrid nano composite materials. Procedia Eng. 2014, 97, 968-974. [CrossRef]

184. Özturk, S. Effect of fiber loading on the mechanical properties of kenaf and fiberfrax fiber-reinforced phenol-formaldehyde composites. J. Compos. Mater. 2010, 44, 2265-2288. [CrossRef]

185. Shahzad, A. Hemp fiber and its composites-A review. Compos. Mater. 2012, 46, 973-986. [CrossRef]

186. Santulli, C. Impact properties of glass/plant fibre hybrid laminates. J. Mater. Sci. 2007, 42, 3699-3707. [CrossRef]

187. Shahzad, A. Impact and fatigue properties of hemp-glass fiber hybrid biocomposites. J. Reinf. Plast. Compos. 2011, 30, 1389-1398. [CrossRef]

188. Mishra, S.M.; Mohanty, A.K.; Drzal, L.T.; Misra, M.; Parija, S.; Nayak, S.K.; Tripathy, S.S. Studies on mechanical performance of biofibre/glass reinforced polyester hybrid composites. Compos. Sci. Technol. 2003, 63, 1377-1385. [CrossRef]

189. Yang, Y.Z.; Zhao, D.; Xu, J.; Dong, Y.; Ma, Y.; Qin, X.; Fujiwara, K.; Suzuki, E.; Furukawa, T.; Takai, Y. Mechanical and optical properties of silk fabric/glass fiber mat composites: An artistic application of composites. Text. Res. J. 2018, 88, 932-945. [CrossRef]

190. Ravandi, M.T.; Teo, W.S.; Tran, L.Q.N.; Yong, M.S.; Tay, T.E. The effects of through-the-thickness stitching on the Mode I interlaminar fracture toughness of flax/epoxy composite laminates. Mater. Des. 2016, 109, 659-669. [CrossRef]

191. Ravandi, M.T.; Teo, W.S.; Yong, M.S.; Tay, T.E. Prediction of Mode I interlaminar fracture toughness of stitched flax fiber composites. J. Mater. Sci. 2018, 53, 4173-4188. [CrossRef] 
192. Jain, L.K.; Mai, Y.W. Determination of mode II delamination toughness of stitched laminated composites. Compos. Sci. Technol. 1995, 55, 241-253. [CrossRef]

193. Ghasemnejad, H.A.Y.; Tez, T.A.; Barrington, P.E. Impact damage response of natural stitched single lap-joint in composite structures. Mater. Des. 2013, 51, 552-560. [CrossRef]

194. Arju, S.N.; Afsar, A.M.; Khan, M.; Das, D. Effects of jute fabric structures on the performance of jute-reinforced polypropylene composites. J. Reinf. Plast. Compos. 2015, 34, 1306-1314. [CrossRef]

195. Kumar, R.K.; Bhowmik, S. Mechanical characterization and quantification of tensile, fracture and viscoelastic characteristics of wood filler reinforced epoxy composite. Wood Sci. Technol. 2018, 52, 677-699. [CrossRef]

196. Bartolomé, J.F.; Gutiérrez-González, C.F.; Torrecillas, R. Mechanical properties of alumina-zirconia- $\mathrm{Nb}$ micro-nano-hybrid composites. Compos. Sci. Technol. 2008, 68, 1392-1398. [CrossRef]

197. Prasob, P.S.M. Static and dynamic behavior of jute/epoxy composites with $\mathrm{ZnO}$ and $\mathrm{TiO} 2$ fillers at different temperature conditions. Polym. Test. 2018, 69, 52-62. [CrossRef]

198. Demirci, M.T.; Necmettin, T.; Avc1, A.; Akdemir, A.; Demirci, I. Fracture toughness (Mode I) characterization of $\mathrm{SiO}_{2}$ nanoparticle filled basalt/epoxy filament wound composite ring with split-disk test method. Compos. Part B Eng. 2017, 119, 114-124. [CrossRef]

199. Zhang, X.; Xiong, R.; Kang, S.; Yang, Y.; Tsukruk, V.V. Alternating Stacking of Nanocrystals and Nanofibers into Ultrastrong Chiral Biocomposite Laminates. ACS Nano 2020. [CrossRef] [PubMed]

200. Göktaş, D.; Kennon, W.; Potluri, P. Improvement of Mode I interlaminar fracture toughness of stitched glass/epoxy composites. Appl. Compos. Mater. 2017, 24, 351-375. [CrossRef]

201. Prasanna, G.V.; Kumar, J.N.; Kumar, K.A. Optimisation \& Mechanical Testing Of Hybrid BioComposites. Mater. Today Proc. 2019, 18, 3849-3855.

202. Siakeng, R.; Jawaid, M.; Ariffin, H.; Sapuan, S. Mechanical, dynamic, and thermomechanical properties of coir/pineapple leaf fiber reinforced polylactic acid hybrid biocomposites. Polym. Compos. 2019, 40, 2000-2011. [CrossRef]

203. Ridzuan, M.; Majid, M.A.; Khasri, A.; Tajul, L.; Cheng, E. Flexural properties of hybrid synthetic/Napier fibres reinforced epoxy composites. In IOP Conference Series: Materials Science and Engineering, Proceedings of the 6th International Conference on Applications and Design in Mechanical Engineering, Penang Island, Malaysia, 26-27 August 2019; IOP Publishing: Bristol, UK, 2019; p. 012034.

204. Ismail, K.; Sultan, M.; Shah, A.; Jawaid, M.; Safri, S. Low velocity impact and compression after impact properties of hybrid bio-composites modified with multi-walled carbon nanotubes. Compos. Part B Eng. 2019, 163, 455-463. [CrossRef]

205. Zin, M.H.; Abdan, K.; Mazlan, N.; Zainudin, E.S.; Liew, K.E.; Norizan, M.N. Automated spray up process for Pineapple Leaf Fibre hybrid biocomposites. Compos. Part B Eng. 2019, 177, 107306. [CrossRef]

206. Del Campo, A.M.; Robledo-Ortiz, J.; Arellano, M.; Jasso-Gastinel, C.; Silva-Jara, J.; López-Naranjo, E.; Pérez-Fonseca, A. GLYCIDYL Methacrylate-Compatibilized Poly (Lactic Acid)/Nanoclay/Agave Fiber Hybrid Biocomposites: Effect on The Physical and Mechanical Properties. Rev. Mex. Ing. Quím. 2020, 19, 455-469. [CrossRef]

207. Duan, J.; Wu, H.; Fu, W.; Hao, M. Mechanical properties of hybrid sisal/coir fibers reinforced polylactide biocomposites. Polym. Compos. 2018, 39, E188-E199. [CrossRef]

208. Ramesh, P.; Prasad, B.D.; Narayana, K. Morphological and mechanical properties of treated kenaf fiber/MMT clay reinforced PLA hybrid biocomposites. In Proceedings of the AIP Conference Proceedings; AIP Publishing LLC: Melville, NY, USA, 2019; p. 020035. [CrossRef]

209. Ribeiro Filho, S.L.M.; Oliveira, P.R.; Vieira, L.M.G.; Panzera, T.H.; Freire, R.T.S.; Scarpa, F. Hybrid bio-composites reinforced with sisal-glass fibres and Portland cement particles: A statistical approach. Compos. Part B Eng. 2018, 149, 58-65. [CrossRef]

210. Khoshnava, S.M.; Rostami, R.; Ismail, M.; Rahmat, A.R.; Ogunbode, B.E. Woven hybrid Biocomposite: Mechanical properties of woven kenaf bast fibre/oil palm empty fruit bunches hybrid reinforced poly hydroxybutyrate biocomposite as non-structural building materials. Constr. Build. Mater. 2017, 154, 155-166. [CrossRef]

211. Mittal, M.; Chaudhary, R. Biodegradability and mechanical properties of pineapple leaf/coir Fiber reinforced hybrid epoxy composites. Mater. Res. Express 2019, 6, 045301. [CrossRef] 
212. Rihayat, T.; Suryani, S.; Fauzi, T.; Agusnar, H.; Wirjosentono, B.; Alam, P.; Sami, M. Mechanical properties evaluation of single and hybrid composites polyester reinforced bamboo, PALF and coir fiber. In IOP Conference Series: Materials Science and Engineering; IOP Publishing: Bristol, UK, 2018; p. 012081. [CrossRef]

213. Nurazzi, N.M.; Khalina, A.; Sapuan, S.M.; Rahmah, M. Development of sugar palm yarn/glass fibre reinforced unsaturated polyester hybrid composites. Mater. Res. Express 2018, 5, 045308. [CrossRef]

214. Rahman, M.; Das, S.; Hasan, M. Mechanical properties of chemically treated banana and pineapple leaf fiber reinforced hybrid polypropylene composites. Adv. Mater. Process. Technol. 2018, 4, 527-537. [CrossRef]

215. Atiqah, A.; Jawaid, M.; Sapuan, S.; Ishak, M. Dynamic mechanical properties of sugar palm/glass fiber reinforced thermoplastic polyurethane hybrid composites. Polym. Compos. 2019, 40, 1329-1334. [CrossRef]

216. Venkatarajan, S.; Bhuvaneswari, B.; Athijayamani, A.; Sekar, S. Effect of addition of areca fine fibers on the mechanical properties of Calotropis Gigantea fiber/phenol formaldehyde biocomposites. Vacuum 2019, 166, 6-10. [CrossRef]

217. Sitticharoen, W.; Aukaranarakul, S.; Kantalue, K. Study of Thermal and Mechanical Properties of LLDPE/Sugarcane bagasse/Eggshell Hybrid Biocomposites. Walailak J. Sci. Technol. 2019, 16, 739-751.

218. Athijayamani, A.; Das, M.C.; Sekar, S.; Ramanathan, K. Mechanical properties of phenol formaldehyde hybrid composites reinforced with natural cellulose fibers. BioResources 2017, 12, 1960-1967. [CrossRef]

219. Jumaidin, R.; Sapuan, S.M.; Jawaid, M.; Ishak, M.R.; Sahari, J. Thermal, mechanical, and physical properties of seaweed/sugar palm fibre reinforced thermoplastic sugar palm starch/agar hybrid composites. Int. J. Biol. Macromol. 2017, 97, 606-615. [CrossRef]

220. Soundhar, A.; Rajesh, M.; Jayakrishna, K.; Sultan, M.; Shah, A. Investigation on mechanical properties of polyurethane hybrid nanocomposite foams reinforced with roselle fibers and silica nanoparticles. Nanocomposites 2019, 5, 1-12. [CrossRef]

221. Petrucci, R.; Santulli, C.; Puglia, D.; Nisini, E.; Sarasini, F.; Tirillò, J.; Torre, L.; Minak, G.; Kenny, J. Impact and post-impact damage characterisation of hybrid composite laminates based on basalt fibres in combination with flax, hemp and glass fibres manufactured by vacuum infusion. Compos. Part B Eng. 2015, 69, 507-515. [CrossRef]

222. Bujjibabu, G.; Das, V.C.; Ramakrishna, M.; Nagarjuna, K. Mechanical and water absorption behavior of natural fibers reinforced polypropylene hybrid composites. Mater. Today Proc. 2018, 5, 12249-12256. [CrossRef]

223. Ramnath, B.V.; Sharavanan, R.; Chandrasekaran, M.; Elanchezhian, C.; Sathyanarayanan, R.; Raja, R.N.; Kokan, S.J. Experimental determination of mechanical properties of banana jute hybrid composite. Fibers Polym. 2015, 16, 164-172. [CrossRef]

224. Sathish, P.; Kesavan, R.; Ramnath, B.V.; Vishal, C. Effect of fiber orientation and stacking sequence on mechanical and thermal characteristics of banana-kenaf hybrid epoxy composite. Silicon 2017, 9, 577-585. [CrossRef]

225. Gupta, M.; Srivastava, R. Mechanical, thermal and water absorption properties of hybrid sisal/jute fiber reinforced polymer composite. Indian J. Eng. Mater. Sci. 2016, 23, 231-238.

226. Aslan, M.; Tufan, M.; Küçükömeroğlu, T. Tribological and mechanical performance of sisal-filled waste carbon and glass fibre hybrid composites. Compos. Part B Eng. 2018, 140, 241-249. [CrossRef]

227. Essabir, H.; Bensalah, M.; Rodrigue, D.; Bouhfid, R.; Qaiss, A. Structural, mechanical and thermal properties of bio-based hybrid composites from waste coir residues: Fibers and shell particles. Mech. Mater. 2016, 93, 134-144. [CrossRef]

228. Yahaya, R.; Sapuan, S.; Jawaid, M.; Leman, Z.; Zainudin, E. Effect of fibre orientations on the mechanical properties of kenaf-aramid hybrid composites for spall-liner application. Def. Technol. 2016, 12, 52-58. [CrossRef]

229. Muhammad, Y.H.; Ahmad, S.; Abu Bakar, M.A.; Mamun, A.A.; Heim, H.P. Mechanical properties of hybrid glass/kenaf fibre-reinforced epoxy composite with matrix modification using liquid epoxidised natural rubber. J. Reinf. Plast. Compos. 2015, 34, 896-906. [CrossRef]

230. Sharba, M.J.; Leman, Z.; Sultan, M.T.; Ishak, M.R.; Hanim, M.A.A. Effects of kenaf fiber orientation on mechanical properties and fatigue life of glass/kenaf hybrid composites. BioResources 2016, 11, 1448-1465. [CrossRef]

231. Braga, R.; Magalhaes, P., Jr. Analysis of the mechanical and thermal properties of jute and glass fiber as reinforcement epoxy hybrid composites. Mater. Sci. Eng. C 2015, 56, 269-273. [CrossRef] [PubMed] 
232. Essabir, H.; Boujmal, R.; Bensalah, M.O.; Rodrigue, D.; Bouhfid, R. Mechanical and thermal properties of hybrid composites: Oil-palm fiber/clay reinforced high density polyethylene. Mech. Mater. 2016, 98, $36-43$. [CrossRef]

233. Safri, S.N.A.; Sultan, M.T.H.; Shah, A.U.M. Characterization of benzoyl treated sugar palm/glass fibre hybrid composites. J. Mater. Res. Technol. 2020, 9, 11563-11573. [CrossRef]

234. Agarwal, J.; Mohanty, S.; Nayak, S.K. Influence of cellulose nanocrystal/sisal fiber on the mechanical, thermal, and morphological performance of polypropylene hybrid composites. Polym. Bull. 2020, 1-27. [CrossRef]

235. Ahmad, M.A.A.; Majid, M.A.; Ridzuan, M.; Mazlee, M.; Gibson, A. Dynamic mechanical analysis and effects of moisture on mechanical properties of interwoven hemp/polyethylene terephthalate (PET) hybrid composites. Constr. Build. Mater. 2018, 179, 265-276. [CrossRef]

236. Suriani, M.; Ruzaidi, C.; Nair, D. Flammability and Mechanical Properties of Arenga Pinnata Fibre/PET Reinforced Epoxy for Fire Retardant Composites. In IOP Conference Series: Materials Science and Engineering; IOP Publishing: Bristol, UK, 2020; p. 012002.

237. George, K.; Mohanty, S.; Biswal, M.; Nayak, S.K. Thermal insulation behaviour of Ethylene propylene diene monomer rubber/kevlar fiber based hybrid composites containing Nanosilica for solid rocket motor insulation. J. Appl. Polym. Sci. 2020, 49934. [CrossRef]

238. Siakeng, R.; Jawaid, M.; Asim, M.; Saba, N.; Sanjay, M.; Siengchin, S.; Fouad, H. Alkali treated coir/pineapple leaf fibres reinforced PLA hybrid composites: Evaluation of mechanical, morphological, thermal and physical properties. Express Polym. Lett. 2020, 14. [CrossRef]

239. Dhakal, H.; Zhang, Z.; Richardson, M. Effect of water absorption on the mechanical properties of hemp fibre reinforced unsaturated polyester composites. Compos. Sci. Technol. 2007, 67, 1674-1683. [CrossRef]

240. Chaudhary, V.; Bajpai, P.K.; Maheshwari, S. Effect of moisture absorption on the mechanical performance of natural fiber reinforced woven hybrid bio-composites. J. Nat. Fibers 2020, 17, 84-100. [CrossRef]

241. Mohanty, A.; Misra, M.; Drzal, L.T. Surface modifications of natural fibers and performance of the resulting biocomposites: An overview. Compos. Interfaces 2001, 8, 313-343. [CrossRef]

242. Thomason, J. The interface region in glass fibre-reinforced epoxy resin composites: 2. Water absorption, voids and the interface. Composites 1995, 7, 477-485. [CrossRef]

243. Espert, A.; Vilaplana, F.; Karlsson, S. Comparison of water absorption in natural cellulosic fibres from wood and one-year crops in polypropylene composites and its influence on their mechanical properties. Compos. Part A Appl. Sci. Manuf. 2004, 35, 1267-1276. [CrossRef]

244. Shen, C.-H.; Springer, G.S. Moisture absorption and desorption of composite materials. J. Compos. Mater. 1976, 10, 2-20. [CrossRef]

245. Venkateshwaran, N.; ElayaPerumal, A. Mechanical and water absorption properties of woven jute/banana hybrid composites. Fibers Polym. 2012, 13, 907-914. [CrossRef]

246. Ray, P.; Chakravarty, A.; Bandyopadhaya, S. Fine structure and mechanical properties of jute differently dried after retting. Appl. Polym. Sci. 1976, 20, 1765-1767. [CrossRef]

247. Semsarzadeh, M.A. Fiber matrix interactions in jute reinforced polyester resin. Polym. Compos. 1986, 7, $23-25$. [CrossRef]

248. Haig Zeronian, S.; Kawabata, H.; Alger, K.W. Factors affecting the tensile properties of nonmercerized and mercerized cotton fibers. Text. Res. J. 1990, 60, 179-183. [CrossRef]

249. Belgacem, M.; Bataille, P.; Sapieha, S. Effect of corona modification on the mechanical properties of polypropylene/cellulose composites. J. Appl. Polym. Sci. 1994, 53, 379-385. [CrossRef]

250. Wang, H.; Rembold, M.; Wang, J. Characterization of surface properties of plasma-polymerized fluorinated hydrocarbon layers: Surface stability as a requirement for permanent water repellency. J. Appl. Polym. Sci. 1993, 49, 701-710. [CrossRef]

251. Enciso, B.; Abenojar, J.; Paz, E.; Martínez, M. Influence of low pressure plasma treatment on the durability of thermoplastic composites LDPE-flax/coconut under thermal and humidity conditions. Fibers Polym. 2018, 19, 1327-1334. [CrossRef]

252. Rong, M.Z.; Zhang, M.Q.; Liu, Y.; Yang, G.C.; Zeng, H.M. The effect of fiber treatment on the mechanical properties of unidirectional sisal-reinforced epoxy composites. Compos. Sci. Technol. 2001, 61, 1437-1447. [CrossRef]

253. Jacob, M.; Varughese, K.; Thomas, S. A study on the moisture sorption characteristics in woven sisal fabric reinforced natural rubber biocomposites. J. Appl. Polym. Sci. 2006, 102, 416-423. [CrossRef] 
254. Ventura, H.; Claramunt, J.; Rodríguez-Pérez, M.; Ardanuy, M. Effects of hydrothermal aging on the water uptake and tensile properties of PHB/flax fabric biocomposites. Polym. Degrad. Stab. 2017, 142, 129-138. [CrossRef]

255. Mishra, S.; Misra, M.; Tripathy, S.; Nayak, S.; Mohanty, A. Potentiality of pineapple leaf fibre as reinforcement in PALF-polyester composite: Surface modification and mechanical performance. J. Reinf. Plast. Compos. 2001, 20, 321-334. [CrossRef]

256. Wang, B.; Panigrahi, S.; Tabil, L.; Crerar, W. Pre-treatment of flax fibers for use in rotationally molded biocomposites. J. Reinf. Plast. Compos. 2007, 26, 447-463. [CrossRef]

257. Halonen, H.; Larsson, P.T.; Iversen, T. Mercerized cellulose biocomposites: A study of influence of mercerization on cellulose supramolecular structure, water retention value and tensile properties. Cellulose 2013, 20, 57-65. [CrossRef]

258. Hashim, M.Y.; Roslan, M.N.; Amin, A.M.; Zaidi, A.M.A.; Ariffin, S. Mercerization treatment parameter effect on natural fiber reinforced polymer matrix composite: A brief review. World Acad. Sci. Eng. Technol. 2012, 68, 1638-1644.

259. Kushwaha, P.K.; Kumar, R. Studies on water absorption of bamboo-polyester composites: Effect of silane treatment of mercerized bamboo. Polym. Plast. Technol. Eng. 2009, 49, 45-52. [CrossRef]

260. Atmakuri, A.; Palevicius, A.; Vilkauskas, A.; Janusas, G. Review of Hybrid Fiber Based Composites with Nano Particles-Material Properties and Applications. Polymers 2020, 12, 2088. [CrossRef]

261. Ramesh, P.; Prasad, B.D.; Narayana, K. Influence of Montmorillonite Clay Content on Thermal, Mechanical, Water Absorption and Biodegradability Properties of Treated Kenaf Fiber/PLA-Hybrid Biocomposites. Silicon 2020, 1-10. [CrossRef]

262. Ramesh, P.; Prasad, B.D.; Narayana, K. Effect of MMT Clay on Mechanical, Thermal and Barrier Properties of Treated Aloevera Fiber/PLA-Hybrid Biocomposites. Silicon 2019, 1-10. [CrossRef]

263. Anbukarasi, K.; Hussain, S.I.; Roseline, A.A.; Kalaiselvam, S. Effect of $\mathrm{SiO}_{2}$ nanospheres on mechanical, thermal and water absorption behaviours of luffa-coir/epoxy hybrid composites. Mater. Res. Express 2019, 6, 125618. [CrossRef]

264. Miao, Y.-G.; Liu, H.-Y.; Suo, T.; Mai, Y.-W.; Xie, F.-Q.; Li, Y.-L. Effects of strain rate on mechanical properties of nanosilica/epoxy. Compos. Part B Eng. 2016, 96, 119-124. [CrossRef]

265. Ulus, H.; Kaybal, H.B.; Eskizeybek, V.; Avc1, A. Enhanced salty water durability of halloysite nanotube reinforced epoxy/basalt fiber hybrid composites. Fibers Polym. 2019, 20, 2184-2199. [CrossRef]

266. Kiatkamjornwong, S. Superabsorbent polymers and superabsorbent polymer composites. ScienceAsia 2007, 33, 39-43. [CrossRef]

267. Vasile, C.; Pamfil, D.; Stoleru, E.; Baican, M. New Developments in Medical Applications of Hybrid Hydrogels Containing Natural Polymers. Molecules 2020, 25, 1539. [CrossRef]

268. Kumar, A.; Lee, Y.; Kim, D.; Rao, K.M.; Kim, J.; Park, S.; Haider, A.; Han, S.S. Effect of crosslinking functionality on microstructure, mechanical properties, and in vitro cytocompatibility of cellulose nanocrystals reinforced poly (vinyl alcohol)/sodium alginate hybrid scaffolds. Int. J. Biol. Macromol. 2017, 95, 962-973. [CrossRef]

269. Rodríguez-Rodríguez, R.; García-Carvajal, Z.; Jiménez-Palomar, I.; Jiménez-Avalos, J.; Espinosa-Andrews, H. Development of gelatin/chitosan/PVA hydrogels: Thermal stability, water state, viscoelasticity, and cytotoxicity assays. J. Appl. Polym. Sci. 2019, 136, 47149. [CrossRef]

270. Sadeghi, A.; Moztarzadeh, F.; Mohandesi, J.A. Investigating the effect of chitosan on hydrophilicity and bioactivity of conductive electrospun composite scaffold for neural tissue engineering. Int. J. Biol. Macromol. 2019, 121, 625-632. [CrossRef]

271. Zhan, H.; Löwik, D.W. A hybrid peptide amphiphile fiber PEG hydrogel matrix for 3D cell culture. Adv. Funct. Mater. 2019, 29, 1808505. [CrossRef]

272. Rose, J.C.; Gehlen, D.B.; Haraszti, T.; Köhler, J.; Licht, C.J.; De Laporte, L. Biofunctionalized aligned microgels provide 3D cell guidance to mimic complex tissue matrices. Biomaterials 2018, 163, 128-141. [CrossRef]

273. De Laporte, L.; Rose, J.; Kivilip, L.; Gehlen, D.; Omidinia, A.; Licht, C.; Rohlfs, W. Magnetic microgel assemblies for injectable soft biocomposites. In Proceedings of the Metal, Mining and Magnetic Materials Conference, Paris, France, 1-2 November 2018. [CrossRef]

274. Ramesh, M.; Palanikumar, K.; Reddy, K.H. Plant fibre based bio-composites: Sustainable and renewable green materials. Renew. Sustain. Energy Rev. 2017, 79, 558-584. [CrossRef] 
275. Akash, G.K.; Venkatesha Gupta, N.; Sreenivas Rao, K. A study on flammability and moisture absorption behavior of sisal/coir fiber reinforced hybrid composites. IOP Conf. Ser. Mater. Sci. Eng. 2017, 191, 012003. [CrossRef]

276. Mittal, M.; Chaudhary, R. Effect of Layering Pattern on Flammability and Water Absorption Behavior of Pineapple Leaf/Coir Fiber Reinforced Hybrid Composites. I-Manag. J. Mater. Sci. 2019, 7, 44.

277. Prakash, V.A.; Viswanthan, R. Fabrication and characterization of echinoidea spike particles and kenaf natural fibre-reinforced Azadirachta-Indica blended epoxy multi-hybrid bio composite. Compos. Part A Appl. Sci. Manuf. 2019, 118, 317-326. [CrossRef]

278. Kc, B.; Tjong, J.; Jaffer, S.; Sain, M. Thermal and dimensional stability of injection-molded sisal-glass fiber hybrid PP biocomposites. J. Polym. Environ. 2018, 26, 1279-1289. [CrossRef]

279. Liew, F.K.; Hamdan, S.; Rahman, M.; Rusop, M. Thermomechanical properties of jute/bamboo cellulose composite and its hybrid composites: The effects of treatment and fiber loading. Adv. Mater. Sci. Eng. 2017, 2017. [CrossRef]

280. Verma, A.; Joshi, K.; Gaur, A.; Singh, V. Starch-Jute fiber hybrid biocomposite modified with Epoxy resin layer: Fabrication and Experimental Characterization. Preprints 2018. [CrossRef]

281. Asim, M.; Paridah, M.; Saba, N.; Jawaid, M.; Alothman, O.Y.; Nasir, M.; Almutairi, Z. Thermal, physical properties and flammability of silane treated kenaf/pineapple leaf fibres phenolic hybrid composites. Compos. Struct. 2018, 202, 1330-1338. [CrossRef]

282. Dinesh, T.; Kadirvel, A.; Vincent, A. Effect of silane modified E-glass fibre/iron (III) oxide reinforcements on UP blended epoxy resin hybrid composite. Silicon 2019, 11, 2487-2498. [CrossRef]

283. Das, G.; Biswas, S. Physical, mechanical and water absorption behaviour of coir fiber reinforced epoxy composites filled with $\mathrm{Al}_{2} \mathrm{O}_{3}$ particulates. In IOP Conference Series: Materials Science and Engineering; IOP Publishing: Bristol, UK, 2016; p. 012012.

284. Swain, P.T.R.; Das, S.N.; Patnaik, P.K.; Purohit, A. The Influence of Moisture Absorption on the Mechanical and Thermal Properties of Chemically Treated DPL Reinforced Hybrid Composite. Mater. Sci. Forum 2020, 978, 316-322. [CrossRef]

285. Almansour, F.; Dhakal, H.; Zhang, Z.Y. Effect of water absorption on Mode I interlaminar fracture toughness of flax/basalt reinforced vinyl ester hybrid composites. Compos. Struct. 2017, 168, 813-825. [CrossRef]

286. Chai, M.; Bickerton, S.; Bhattacharyya, D.; Das, R. Influence of natural fibre reinforcements on the flammability of bio-derived composite materials. Compos. Part B Eng. 2012, 43, 2867-2874. [CrossRef]

287. Das, O.; Kim, N.K.; Sarmah, A.K.; Bhattacharyya, D. Development of waste based biochar/wool hybrid biocomposites: Flammability characteristics and mechanical properties. J. Clean. Prod. 2017, 144, 79-89. [CrossRef]

288. Dorez, G.; Taguet, A.; Ferry, L.; Cuesta, J.-M.L. Phosphorous compounds as flame retardants for polybutylene succinate/flax biocomposite: Additive versus reactive route. Polym. Degrad. Stab. 2014, 102, 152-159. [CrossRef]

289. Szolnoki, B.; Bocz, K.; Soti, P.L.; Bodzay, B.; Zimonyi, E.; Toldy, A.; Morlin, B.; Bujnowicz, K.; Wladyka-Przybylak, M.; Marosi, G. Development of natural fibre reinforced flame retarded epoxy resin composites. Polym. Degrad. Stab. 2015, 119, 68-76. [CrossRef]

290. Saba, N.; Jawaid, M.; Paridah, M.; Al-Othman, O. A review on flammability of epoxy polymer, cellulosic and non-cellulosic fiber reinforced epoxy composites. Polym. Adv. Technol. 2016, 27, 577-590. [CrossRef]

291. Babu, K.; Rendén, G.; Afriyie Mensah, R.; Kim, N.K.; Jiang, L.; Xu, Q.; Restás, Á.; Esmaeely Neisiany, R.; Hedenqvist, M.S.; Försth, M. A review on the flammability properties of carbon-based polymeric composites: State-of-the-art and future trends. Polymers 2020,12, 1518. [CrossRef]

292. Feng, Y.; He, C.; Wen, Y.; Ye, Y.; Zhou, X.; Xie, X.; Mai, Y.-W. Superior flame retardancy and smoke suppression of epoxy-based composites with phosphorus/nitrogen co-doped graphene. J. Hazard. Mater. 2018, 346, 140-151. [CrossRef]

293. Araby, S.; Su, X.; Meng, Q.; Kuan, H.-C.; Wang, C.-H.; Mouritz, A.; Maged, A.; Ma, J. Graphene platelets versus phosphorus compounds for elastomeric composites: Flame retardancy, mechanical performance and mechanisms. Nanotechnology 2019, 30, 385703. [CrossRef]

294. Lee, S.; Min Kim, H.; Seong, D.G.; Lee, D. Synergistic improvement of flame retardant properties of expandable graphite and multi-walled carbon nanotube reinforced intumescent polyketone nanocomposites. Carbon 2019, 143, 650-659. [CrossRef] 
295. Mochane, M.J.; Motaung, T.E.; Motloung, S.V. Morphology, flammability, and properties of graphite reinforced polymer composites. Systematic review. Polym. Compos. 2018, 39, E1487-E1499. [CrossRef]

296. Mngomezulu, M.E.; Luyt, A.S.; John, M.J. Morphology, thermal and dynamic mechanical properties of poly (lactic acid)/expandable graphite (PLA/EG) flame retardant composites. J. Thermoplast. Compos. Mater. 2019, 32, 89-107. [CrossRef]

297. Kanbur, Y.; Tayfun, U. Development of multifunctional polyurethane elastomer composites containing fullerene: Mechanical, damping, thermal, and flammability behaviors. J. Elastomers Plast. 2019, 51, 262-279. [CrossRef]

298. Chen, Q.; Sai, T.; Fang, Z.; Guo, Z. Thermal stability and oxygen resistance of polypropylene composites with fullerene/montmorillonite hybrid fillers. J. Therm. Anal. Calorim. 2020, 1-10. [CrossRef]

299. Qiu, M.; Wang, D.; Zhang, L.; Li, M.; Liu, M.; Fu, S. Simultaneously electrochemical exfoliation and functionalization of graphene nanosheets: Multifunctional reinforcements in thermal, flame-retardant, and mechanical properties of polyacrylonitrile composite fibers. Polym. Compos. 2020, 41, 1561-1573. [CrossRef]

300. Zhao, Z.; Cai, W.; Xu, Z.; Mu, X.; Ren, X.; Zou, B.; Gui, Z.; Hu, Y. Multi-role p-styrene sulfonate assisted electrochemical preparation of functionalized graphene nanosheets for improving fire safety and mechanical property of polystyrene composites. Compos. Part B Eng. 2020, 181, 107544. [CrossRef]

301. Yang, W.; Tawiah, B.; Yu, C.; Qian, Y.-F.; Wang, L.-L.; Yuen, A.C.-Y.; Zhu, S.-E.; Hu, E.-Z.; Chen, T.B.-Y.; Yu, B. Manufacturing, mechanical and flame retardant properties of poly (lactic acid) biocomposites based on calcium magnesium phytate and carbon nanotubes. Compos. Part A Appl. Sci. Manuf. 2018, 110, 227-236. [CrossRef]

302. Kanbur, Y.; Tayfun, U. Investigating mechanical, thermal, and flammability properties of thermoplastic polyurethane/carbon nanotube composites. J. Thermoplast. Compos. Mater. 2018, 31, 1661-1675. [CrossRef]

303. Kabir, I.I.; Fu, Y.; de Souza, N.; Nazir, M.T.; Baena, J.C.; Yuen, A.C.Y.; Yeoh, G.H. Improved flame-retardant properties of polydimethylsiloxane/multi-walled carbon nanotube nanocomposites. J. Mater. Sci. 2020, 1-20. [CrossRef]

304. Rahimi-Aghdam, T.; Shariatinia, Z.; Hakkarainen, M.; Haddadi-Asl, V. Polyacrylonitrile/N, P co-doped graphene quantum dots-layered double hydroxide nanocomposite: Flame retardant property, thermal stability and fire hazard. Eur. Polym. J. 2019, 120, 109256. [CrossRef]

305. Kausar, A. Epoxy and quantum dots-based nanocomposites: Achievements and applications. Mater. Res. Innov. 2020, 24, 235-243. [CrossRef]

306. Zhang, Q.; Cai, H.; Yang, K.; Yi, W. Effect of biochar on mechanical and flame retardant properties of wood-plastic composites. Results Phys. 2017, 7, 2391-2395. [CrossRef]

307. Savi, P.; Josè, S.P.; Khan, A.; Giorcelli, M.; Tagliaferro, A. Biochar and Carbon Nanotubes as fillers in polymers: A comparison. In Proceedings of the 2017 IEEE MTT-S International Microwave Workshop Series on Advanced Materials and Processes for RF and THz Applications (IMWS-AMP), Pavia, Italy, 20-22 September 2017; pp. 1-3.

308. Dasari, A.; Yu, Z.-Z.; Cai, G.-P.; Mai, Y.-W. Recent developments in the fire retardancy of polymeric materials. Prog. Polym. Sci. 2013, 38, 1357-1387. [CrossRef]

309. Dasari, A.; Cai, G.-P.; Mai, Y.-W.; Yu, Z.-Z. Flame retardancy of polymer-clay nanocomposites. In Physical Properties and Applications of Polymer Nanocomposites; Elsevier: Amsterdam, The Netherlands, 2010; pp. 347-403.

310. Dewaghe, C.; Lew, C.; Claes, M.; Dubois, P. Fire-retardant applications of polymer-carbon nanotubes composites: Improved barrier effect and synergism. In Polymer-Carbon Nanotube Composites; Elsevier: Amsterdam, The Netherlands, 2011; pp. 718-745.

311. Sajna, V.; Mohanty, S.; Nayak, S.K. A study on thermal degradation kinetics and flammability properties of poly (lactic acid)/banana fiber/nanoclay hybrid bionanocomposites. Polym. Compos. 2017, 38, 2067-2079. [CrossRef]

312. Dashtizadeh, Z.; Abdan, K.; Jawaid, M.; Dashtizadeh, M. Thermal and Flammability Properties of Kenaf/Recycled Carbon Filled with Cardanol Hybrid Composites. Int. J. Polym. Sci. 2019, 2019. [CrossRef]

313. Shivamurthy, B.; Thimmappa, B.; Monteiro, J. Sliding wear, mechanical, flammability, and water intake properties of banana short fiber/Al (OH) 3/epoxy composites. J. Nat. Fibers 2020, 17, 337-345. [CrossRef]

314. Zuhudi, N.Z.M.; Lin, R.J.; Jayaraman, K. Flammability, thermal and dynamic mechanical properties of bamboo-glass hybrid composites. J. Thermoplast. Compos. Mater. 2016, 29, 1210-1228. [CrossRef] 
315. Idumah, C.I.; Hassan, A.; Bourbigot, S. Influence of exfoliated graphene nanoplatelets on flame retardancy of kenaf flour polypropylene hybrid nanocomposites. J. Anal. Appl. Pyrolysis 2017, 123, 65-72. [CrossRef]

316. Subasinghe, A.; Somashekar, A.A.; Bhattacharyya, D. Effects of wool fibre and other additives on the flammability and mechanical performance of polypropylene/kenaf composites. Compos. Part B Eng. 2018, 136, 168-176. [CrossRef]

317. Chee, S.S.; Jawaid, M.; Alothman, O.Y.; Yahaya, R. Thermo-oxidative stability and flammability properties of bamboo/kenaf/nanoclay/epoxy hybrid nanocomposites. RSC Adv. 2020, 10, 21686-21697. [CrossRef]

318. Ezeh, E.; Onukwuli, O.; Odera, R.; Ugonabo, V.; Okeke, O. Thermal Decomposition and Flame retardancy of Functional Polyester/Banana Peduncle fibre and Aluminum Hydroxide particle Hybrid Composites. Chem. Process. Eng. Res. 2020, 62. [CrossRef]

319. Saba, N.; Jawaid, M.; Alrashed, M.M.; Alothman, O.Y. Oil palm waste based hybrid nanocomposites: Fire performance and structural analysis. J. Build. Eng. 2019, 25, 100829. [CrossRef]

Publisher's Note: MDPI stays neutral with regard to jurisdictional claims in published maps and institutional affiliations.

(C) 2020 by the authors. Licensee MDPI, Basel, Switzerland. This article is an open access article distributed under the terms and conditions of the Creative Commons Attribution (CC BY) license (http://creativecommons.org/licenses/by/4.0/). 